\title{
Ireland: Request for an Extended Arrangement—Staff Report; Staff Supplement; Staff Statement; and Press Release on the Executive Board Discussion.
}

In the context of the request for an Extended Arrangement, the following documents have been released and are included in this package:

- $\quad$ The staff report for the Request for an Extended Arrangement, prepared by a staff team of the IMF, following discussions that ended on November 30, 2010 with the officials of Ireland on economic developments and policies. Based on information available at the time of these discussions, the staff report was completed on December 4, 2010. The views expressed in the staff report are those of the staff team and do not necessarily reflect the views of the Executive Board of the IMF.

- A staff supplement of December 10, 2010 on the assessment of the risks to the Fund and the Fund's liquidity position.

- A staff statement of December 10, 2010 updating information on recent developments.

- $\quad$ A Press Release summarizing the views of the Executive Board as expressed during its December 16, 2010 discussion of the staff report that completed the request.

The documents listed below have been or will be separately released.

Letter of Intent sent to the IMF by the authorities of Ireland*

Memorandum of Economic and Financial Policies by the authorities of

Ireland*

Technical Memorandum of Understanding*

*Also included in Staff Report

The policy of publication of staff reports and other documents allows for the deletion of market-sensitive information.

\author{
Copies of this report are available to the public from \\ International Monetary Fund • Publication Services \\ $70019^{\text {th }}$ Street, N.W. • Washington, D.C. 20431 \\ Telephone: (202) 623-7430 • Telefax: (202) 623-7201 \\ E-mail: publications@imf.org Internet: http://www.imf.org
}

\section{International Monetary Fund Washington, D.C.}


INTERNATIONAL MONETARY FUND

IRELAND

\title{
Request for an Extended Arrangement
}

\author{
Prepared by the European Department in Consultation with Other Departments
}

Approved by Ajai Chopra and Martin Mühleisen

December 4, 2010

\section{Executive Summary}

\section{Background}

- Despite the authorities' bold economic policies in a difficult environment, Ireland has faced intense economic and financial pressures in recent months. At the root of its problems is a critically-weakened banking sector that has yet to be restored to health and stands at the center of a dynamic that dampens economic recovery while creating pressures on an already serious fiscal challenge.

- Layered on these difficulties is the fall in domestic consumer and international investor confidence, with implications for growth and the cost of funding.

- The program aims to restore Ireland's banking system to health and put its public finances on a sound footing, thus renewing confidence and a return to strong, sustained, growth.

\section{Main elements of the program}

- Achieve a smaller, more robust banking sector to serve Irish economic needs. While this process will take time, it will start immediately and will move with deliberate speed.

- Banks will maintain higher capital adequacy standards to minimize market perceptions of weakness, and thereby achieve improved access to funding.

- The authorities' National Recovery Plan will form the basis of 2011 and subsequent budgets. The Plan makes pragmatic choices to achieve consolidation in a fair manner.

- While Ireland's business environment is very strong, the program addresses remaining impediments that might underpin competitiveness in the years ahead, supporting growth.

- A financing package of $€ 85$ billion will support these far reaching changes

- In the attached Letter of Intent (LOI) and Memorandum of Economic and Financial Policies (MEFP), the authorities request a three-year Extended Arrangement under the Extended Fund Facility (EFF) under the exceptional access policy and the emergency financing mechanism. The Fund will contribute SDR 19.5 billion ( $€ 22.5$ billion, equivalent to 2,321.8 percent of quota) and make available SDR 5 billion on Board approval.

- The Irish authorities will contribute $€ 17.5$ billion to this effort from the nation's cash reserves and liquid assets. The European Union and bilateral European lenders will provide the remaining $€ 45$ billion on similar terms as those under the EFF, with whom the cooperation will continue. ECB liquidity support is an essential component of the program.

- High program risks reflect uncertain bank losses, a difficult debt outlook despite an unprecedented fiscal adjustment, unclear growth prospects, continued market focus on peripheral Europe countries, and an impending general election. 
Discussions were held in Dublin during November 18-30, 2010. The IMF team comprised Ali Abbas, Bergljot Barkbu, Pierluigi Bologna, Alberto Buffa di Perrero, Ajai Chopra, Luis Cortavarria, David Hawley, Maike Luedersen, Johan Mathisen, Donal McGettigan, Ashoka Mody, Dilcia Noren, Ceyla Pazarbasioglu, Silvia Sgherri, and Olga Stankova. The mission worked in conjunction with representatives from the European Commission and the European Central Bank. The mission is grateful to the Irish authorities for the productive discussions and their hospitality.

Contents

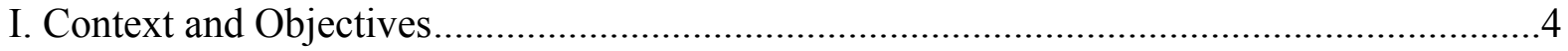

II. Recent Economic and Political Developments ..................................................... 7

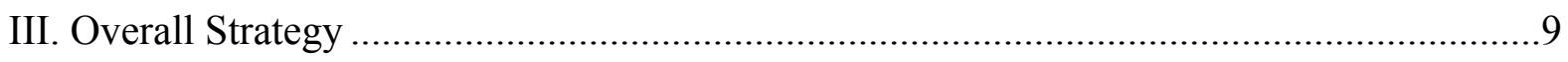

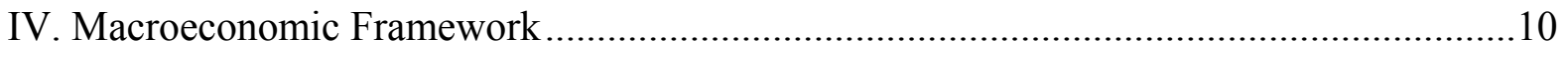

V. Returning the Banking System to Healthy Functionality ...........................................13

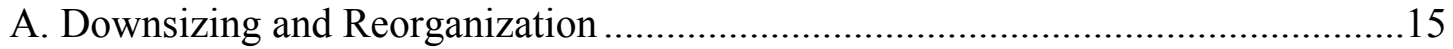

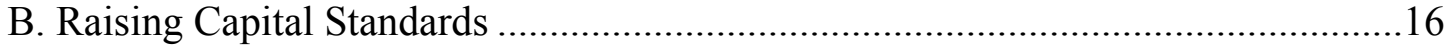

C. Reducing Risk and Increasing Shock Absorption Capacity................................19

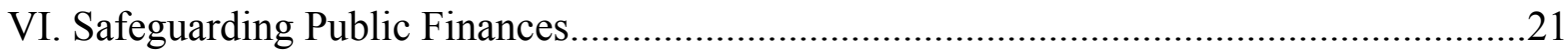

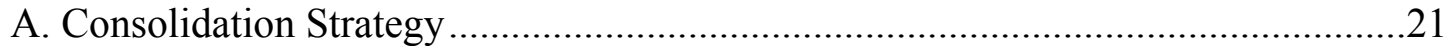

B. The National Recovery Plan and Program Targets ...........................................23

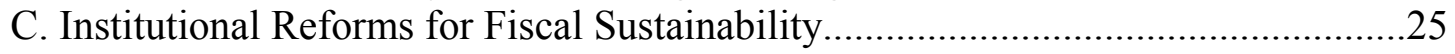

VII. Structural Reforms to Raise Efficiency and Growth Potential....................................26

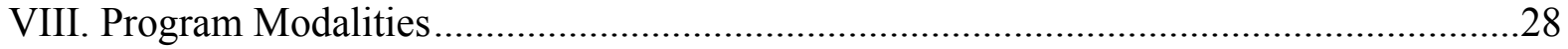

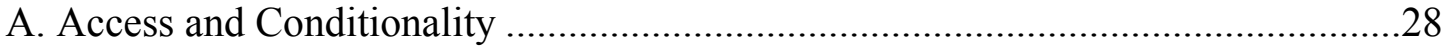

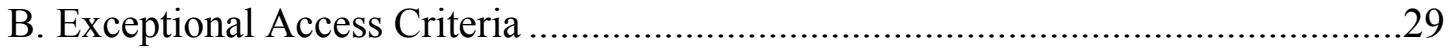

C. Capacity to Repay the Fund and Risks to the Program..........................................30

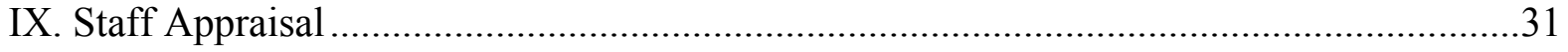

Tables

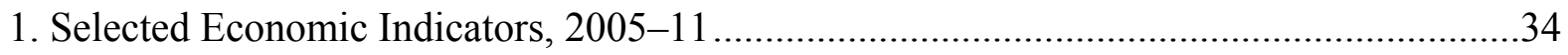

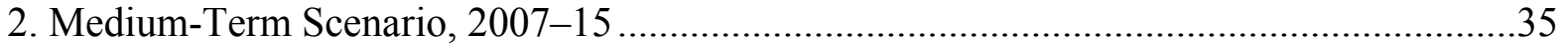

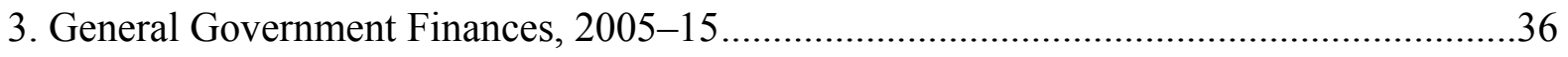

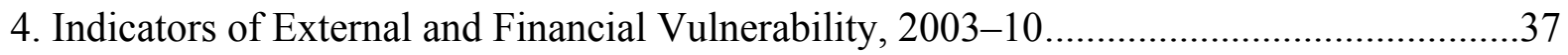

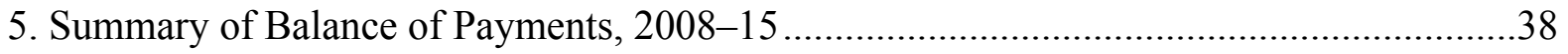

6. External Financing Requirements and Sources, 2008-15 ............................................39

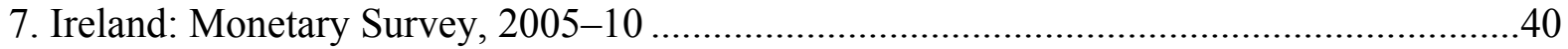

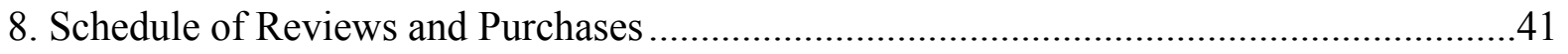

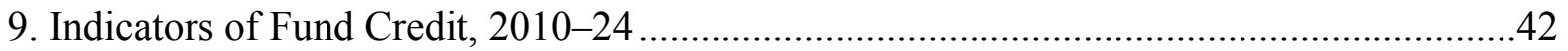


Boxes

1. Spillovers from Ireland

2. Government Support of the Financial Sector, September 2008-October 2010.................9

3. Methodology to Conduct a Second Stress Test Exercise (PCAR 2011) ...........................17

4. Initial Terms of Reference for Data Quality and Asset Quality Diagnostic Review..........18

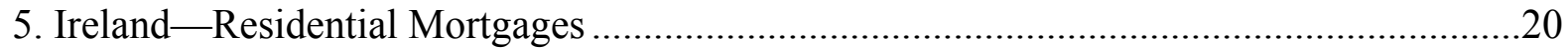

6. Reducing Impediments to Competitiveness and Employment Creation ...........................27

Appendix

I. Debt Sustainability Analysis 


\section{ConteXt AND OBJECTIVES}

1. The economic and financial pressures facing Ireland are intense. At the heart of the problem is Ireland's banking sector, which is over-sized relative to the economy and holds sizeable vulnerable assets despite major support measures taken by the authorities. These deep-rooted structural problems have resulted in a marked erosion of confidence, leading to a loss of deposits and market funding, almost all of which in recent months has been replaced by ECB funding. These concerns have come to a head, as the banking sector's woes have eroded the sovereign's credibility at a gathering pace.

The widening of sovereign spreads is reminiscent of the Greek crisis

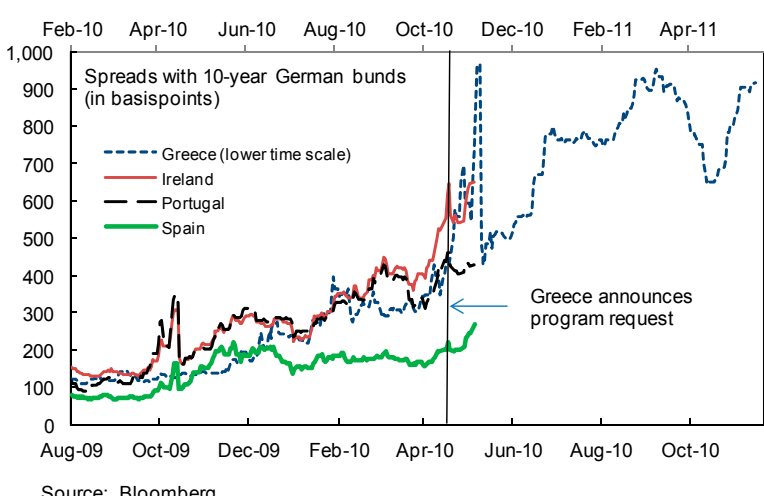

2. With the banking sector at the fulcrum of Ireland's problems, low growth, fiscal sustainability concerns, and banking vulnerabilities are feeding on each other.

- The economic outlook is uncertain. The economy is undergoing a profound adjustment as the imbalances from the boom years unwind. Following a sharp fall in output in 2008-09, the pace of recovery is projected to be modest. Downside risks are significant, stemming from deflationary tendencies, overstretched balance sheets, and adverse fiscal and financial feedback loops.

- The authorities have taken major measures to strengthen the banking sector but vulnerabilities remain acute. The National Asset Management Agency (NAMA) is taking over banks' land and property development assets; substantial capital has been injected, and sovereign guarantees have been provided to reassure banks' creditors. However, market pressures continue to pose challenges to the large rollover needs, threatening banking system solvency and placing a severe burden on the sovereign's finances.

- Continued large fiscal consolidation is needed to secure debt sustainability. Moving early, the Irish authorities implemented sizeable fiscal consolidation over 2009-10. However, public finances have been weighed down by a deep structural deficit, bank support, and weak growth. Public debt is, as a result, projected to end up close to 100 percent of GDP by end-2010. To help stabilize public debt, the authorities' consolidation plan includes another $€ 15$ billion in consolidation measures over 2011-14, equivalent to 9 percent of GDP.

3. The program therefore aims to restore the banking system to health and, thus, snap the pernicious feedback loops between growth, fiscal, and financial instability. This requires a multifaceted approach: 
- A fundamentally restructured banking system that downsizes the banking sector (while addressing market perceptions of weak bank capital positions).

- Safeguarding the fiscal consolidation plan to lower the deficit and debt over the medium term, with the burden of consolidation distributed fairly.

- Institutional reform to improve the shock-absorbing capacity of the economy: a special resolution regime for banks, stronger supervision, and greater budgetary oversight.

- $\quad$ Further reforms to improve the economy's efficiency to enhance growth potential.

- $\quad$ Large external financial assistance to manage the transition and reestablish muchneeded policy credibility.

The stability thus generated - along with improved competitiveness and increased credit flows - would underpin a return of confidence, and, hence, brighter employment and growth prospects.

\section{By restoring financial stability to Ireland, the contagion threat to other countries} would be contained. The contagion threat from Ireland is significant. This risk arises principally because of the market's perception that Ireland's vulnerabilities are similar to those of other euro area peripheral economies. In contrast, the direct exposure of international banks to the Irish banking sector is much less salient than is sometimes inferred from the often-cited Bank of International Settlement statistics, which report aggregates that include Ireland's sizeable international financial services (IFSC) industry. The largely selfcontained IFSC has limited links to domestic banks and has not been a source of instability. The international exposure to domestic banks, particularly those covered by the Irish government's guarantee, is, according to the Central Bank, a small fraction of the aggregate numbers. The contagion risk nevertheless is significant since banks across the periphery are perceived to face common vulnerabilities. Stress in the domestic banks also tends to weaken the sovereign's credit. The evidence is that the Irish sovereign and banks' weaknesses have been transmitted to other peripheral economies (Box 1). Looking ahead, the risk is that under high stress conditions, spillover effects to other peripheral euro area economies could be large and extend beyond the euro area. Also, while the Irish correlations with the U.K. and U.S. markets have not been notable recently, a disorderly eruption of financial pressures in Ireland could have wider implications through connections to those markets. 


\section{Box 1. Spillovers from Ireland}

Country-specific spillover risks from the Irish sovereign are significant. Ireland has strong financial linkages to the rest of the world and the contagion threat from Ireland could be significant. Given market perceptions, spillover effects to other peripheral euro-area economies could be large. Greece, Portugal, and Spain are the most vulnerable to volatility spillovers from an event in Ireland. Other euro-area sovereigns show negative country-specific crosscorrelations, while Italy and Belgium appear like borderline cases.

Systemic tail risks from the large Irish banks are also elevated. Distress in both Allied Irish Bank and Bank of Ireland - the two largest Irish banks - would very likely be followed by distress in other European banks. The estimated conditional probability of distress in at least another European bank given distress in Irish banks is over two-thirds. This would particularly be the case for Greek and Portuguese banks.
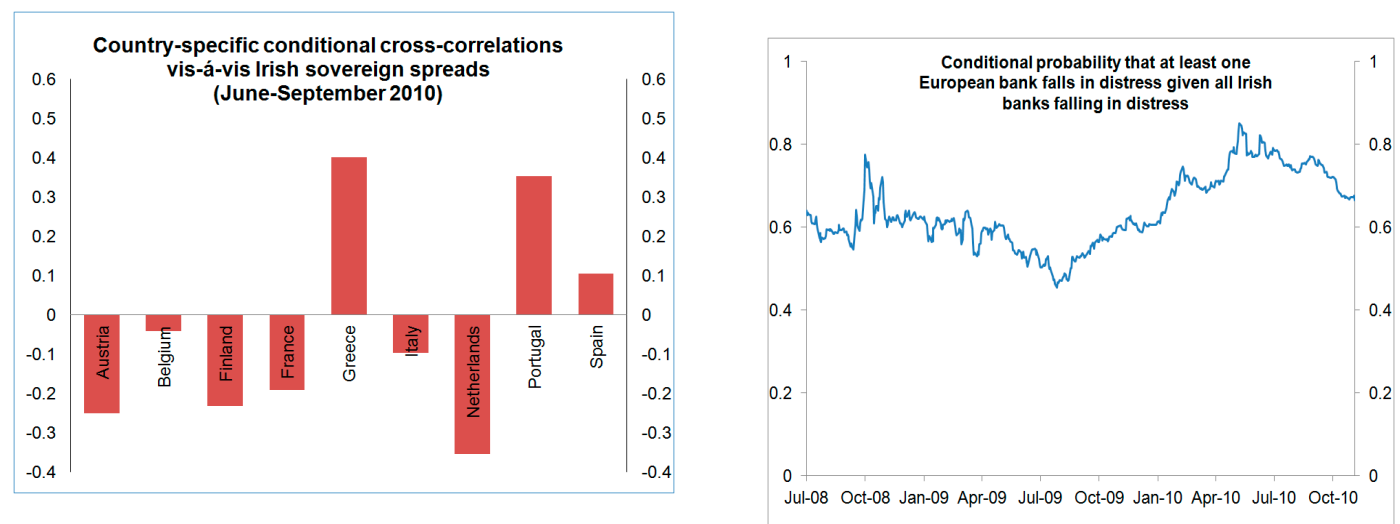

Disorderly eruption of financial pressures in Ireland could have wider implications through foreign banks' exposure to Ireland. German and U.K. banks have the largest exposure to Ireland ( $€ 113$ billion and $€ 107$ billion, respectively), followed by U.S. ( $€ 47$ billion), French ( $€ 36$ billion), and Belgian ( $€ 24$ billion) banks. As a percent of home country banking system assets, banks from Belgium (2.2 percent), Germany (1.8 percent), and the U.K. (1.3 percent) are the most exposed. However, global banks' direct exposure to Irish sovereign debt remains very limited.

Portfolio investments are another potential channel of financial contagion. The countries with the largest portfolio investments in Ireland are the U.K. (€134 billion), Germany ( $€ 112$ billion), France ( $€ 95$ billion), and the U.S. ( $€ 83$ billion). Relative to home country GDP, the most exposed countries are Portugal (18.8 percent), the U.K. (8.9 percent), Belgium (8.1 percent), the Netherlands (6.2 percent), Switzerland (5.9 percent), France (5.2 percent), and Germany ( 4.8 percent). The largest part of foreign portfolio claims on Ireland is generally in the form of long-term debt securities, with the exception of the US, Switzerland and Sweden where equity securities are more important. 


\section{Recent Economic and Political Developments}

5. Following a precipitous fall, the economy is stabilizing. The economy contracted by 11 percent in real terms and 16 percent in nominal terms during 2008-09. Growth in the first half of 2010 was modestly positive but, with a large negative carry-over from 2009 and recent market turmoil, the 2010 GDP is projected by staff to be $1 / 4$ percent lower than in 2009 . Recent concurrent and leading indicators show weak retail trade and sentiment measures. Consumer prices are expected to fall by a further $1 \frac{1}{2}$ percent this year, bringing the cumulative price decline to 6 percent. The fall in housing prices - 36 percent since their peak - continues, but at a slowing pace.
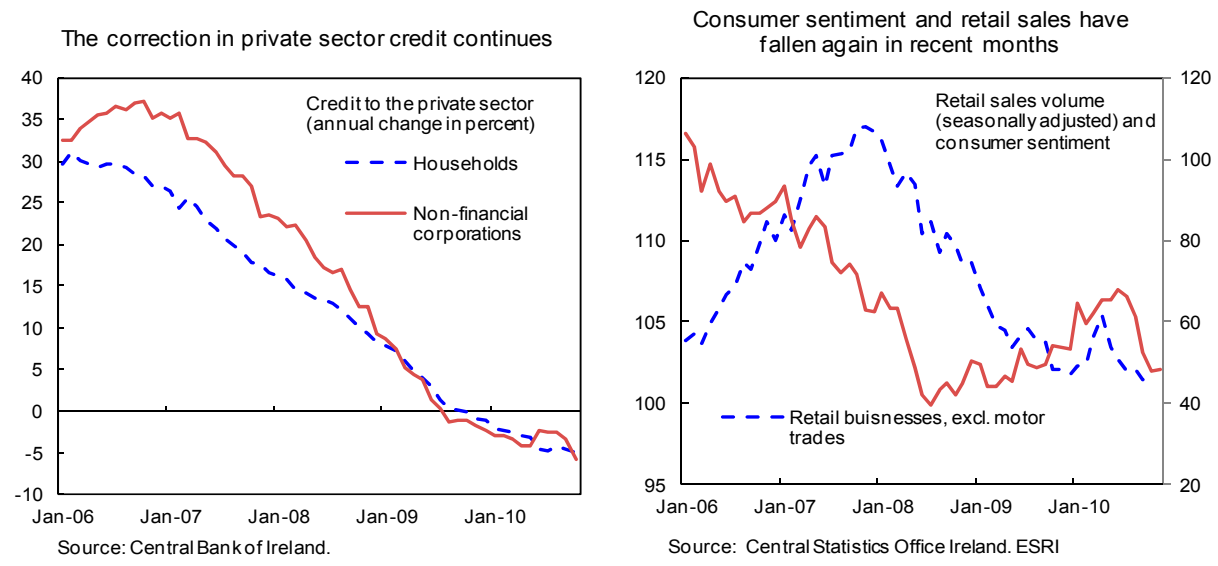

6. The domestic banking sector liquidity crisis remains acute. Banks have been unable to rollover large maturing bank obligations and deposit outflows - mainly commercial deposits - have continued. As a result, the banking system - at 500 percent of GDP — has become almost fully dependent on continued ECB liquidity support. ${ }^{1}$ Moreover, the Central Bank of Ireland provides emergency liquidity assistance (ELA) to banks where that is judged necessary. ${ }^{2}$

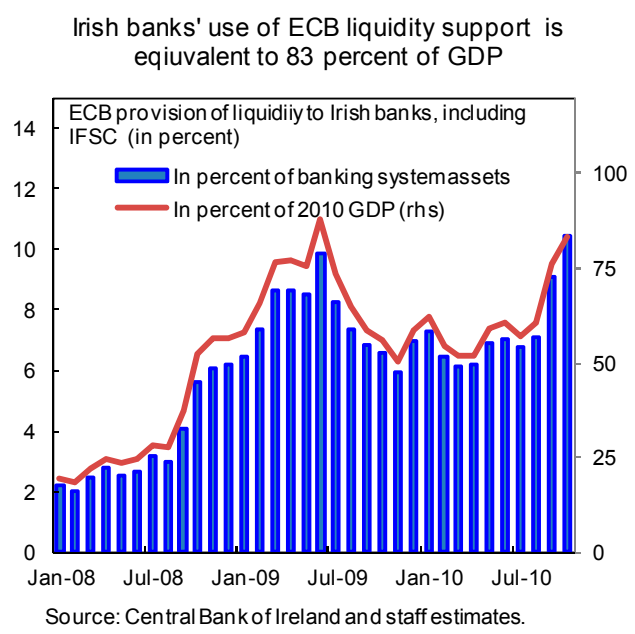

\footnotetext{
${ }^{1}$ At end-September 2010, the domestic banking system accounted for 490 percent of GDP and the domestically-owned banking system for 325 percent of GDP.

${ }^{2}$ Under ELA, some banks may obtain liquidity from the Central Bank of Ireland, outside the ECB monetary policy framework, under specific circumstances, and with special terms and conditions attached.
} 

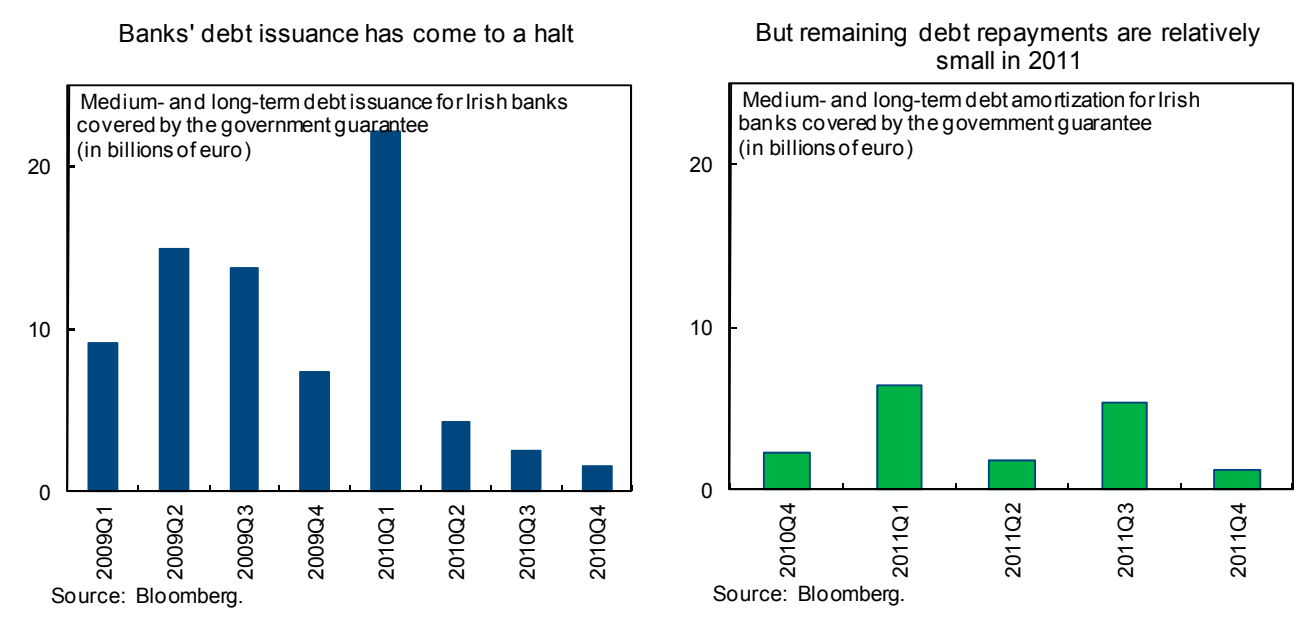

7. The fragile banking system remains the key threat to public finances. The Irish authorities have taken strong and repeated action to counter the large structural deficit (Box 2). But while large adjustment needs remain, bank support has added to the fiscal burden. The deficit is expected to reach 32 percent of GDP in 2010, reflecting bank recapitalization of 20 percent of GDP. Government debt will reach 99 percent of GDP by end-2010. The government's obligations to the financial sector have pushed spreads on government bonds to historic highs and significantly reduced market access for the sovereign.

8. Tackling the crisis has taken a political toll. Until recently, deep consolidation has been implemented in a remarkably socially-cohesive manner. This reflects a tradition of social partnership that has served well despite the difficult choices that have had to be made. However, with continued upward revisions of the consolidation needed and of the costs of supporting the financial sector, frustration has mounted. The government has announced it will call early elections. The ruling party, Fianna Fáil, is trailing in the opinion polls. The mission met with opposition parties and the main ones indicated broad support for the program objectives of achieving financial sector and fiscal stability, but indicated their interest in revisiting some of the policy approaches to achieve these objectives. 


\section{Box 2. Government Support of the Financial Sector, September 2008-October 2010}

The authorities' extensive support has been vital to address financial stability concerns. The measures have been guided by the European Union framework for state aid. Also, access to ECB liquidity support has been an important stabilizing factor.

- Government guarantees of domestic banks' liabilities. A guarantee on the liabilities of seven banks was put in place in September 2008 under the Credit Institutions Financial Support Scheme (CIFS), which expired in September 2010. The CIFS covered all existing and new bank liabilities, excluding retail deposits covered by the statutory deposit guarantee scheme. A new scheme was put in place in December 2009, the Credit Institutions Eligible Liability Guarantee (ELG) Scheme, replacing the CIFS in covering newly issued bank liabilities. The ELG scheme covers senior debt and deposits with maturities of less than five years. The scheme has been extended through endDecember 2011, and the EC has approved the extension through end-June 2011.

- The National Asset Management Agency (NAMA) was established in late 2009, to take over banks' distressed land and property development assets. The participating banks receive government-guaranteed securities in return for the assets. By August 2010, NAMA had acquired assets with a nominal value of some $€ 27$ billion, at an average discount of over 50 percent. NAMA is expected to complete its acquisitions by January 2011, in a total amount of $€ 73$ billion. The transfer of assets by the banks at a price below their book value implies that these banks will need additional capital.

- Financing to boost banks' capital ratios. In March 2010, the Financial Regulator determined a target capital ratio for banks of 8 percent for Core Tier 1 capital, of which 7 percent is to be equity capital, taking into account losses from NAMA transfers as well as expected losses on non-NAMA assets until 2012. Required capital injections also were set to ensure that banks Core Tier 1 capital remains above 4 percent in a stress scenario. During 2009-10, the government has provided capital injections of $€ 45$ billion.

\section{OVerall Strategy}

9. The authorities' program addresses head on Ireland's key challenges:

- $\quad$ Restoring the banking system to health. The banking system needs to be restructured and recapitalized. The program's key objectives are, therefore, to reduce the size of the sector to a manageable level, separate good assets from bad, and reduce dependence on wholesale funding. The capital position of banks will also be bolstered under the program. These measures should help restore confidence in the system over time and allow for renewed access to market funding at reasonable costs. Once the process takes hold, the banking sector will be in a better position to meet the credit needs of the economy.

- Underpinning fiscal sustainability. The program builds on the authorities' own National Recovery Plan. This calls for large further frontloaded fiscal adjustment, with two-thirds of the adjustment coming from spending, and the remainder from revenues. This will in turn support Ireland's medium-term public debt prospects. At the same time, important structural fiscal reforms will play an important role, including a new budget formation process, which comprises a new Fiscal 
Responsibility Law (medium-term spending framework), and a new Budget Advisory Council (independent budget assessment).

- $\quad$ Securing sustainable economic growth. Ireland already has a competitive business environment. That said, the mutually-reinforcing problems of government (high deficit and debt), private sector (weak balance sheets), and the financial sector suggest that the economy will go through a prolonged structural adjustment phase that may lower growth prospects. The program aims to snap the pernicious feedback loops between these vulnerabilities by restructuring the banking system, restoring fiscal sustainability and putting in place new fiscal processes, as described above, and implementing other structural reforms (including reducing trade restrictions) that will copper-fasten Ireland's growth prospects.

\section{Substantial external financial assistance will provide support for these strategies.} Ireland is expected to have a large balance of payments need over 2011-13, in particular, to finance the buildup of reserves to improve banks' ability to meet their large external debt rollover needs and prevent substantial capital outflows. The program aims at gradually restoring market access, ensuring that any financial account shortfall is temporary. At the same time, the ECB would need to continue providing liquidity support to the domestic banking sector, as needed, over the course of the program.

\section{The Fund-supported program has been formulated in close collaboration with} the EC and the ECB. The EC and ECB have been involved in all aspects of the discussions, and helped contribute to a truly joint program with the authorities.

\section{Macroeconomic Framework}

\section{The economy is expected to stabilize and begin to} recover in 2011. Staff projects growth to recover from $-1 / 4$ percent in 2010 to 1 percent in 2011 . Growth in trading partner countries, though moderating from 2010, will support a continued recovery of exports. Investment spending is projected to continue contracting - albeit at a moderating rate - reflecting the planned reduction in public infrastructural investment and the overhang of unsold residential and commercial properties. Unemployment is likely to persist at about $13 \frac{1}{2}$ percent in 2011 contributing, along with fiscal consolidation to a reduction of real disposable income. Offsetting these contractionary tendencies, the savings ratio,

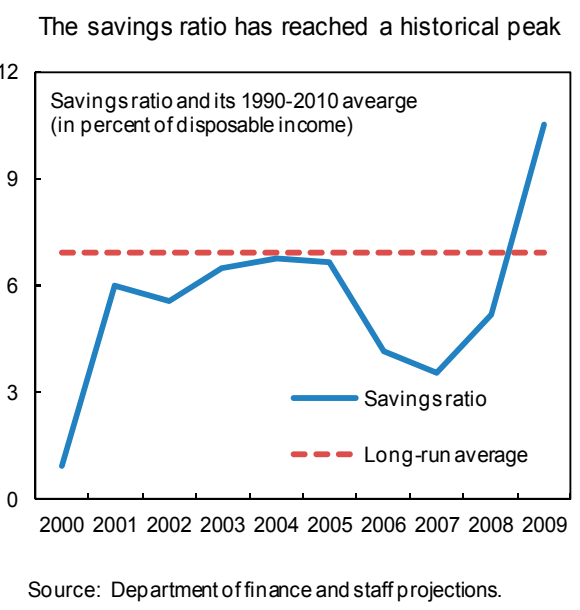
having reached record-high levels in 2010, could decrease as the limits of precautionary savings are reached. Despite this cushioning effect, private consumption is projected to fall by $1 \frac{1}{2}$ percent of GDP. However, these judgments are necessarily imprecise. The authorities expect smaller headwinds from fiscal consolidation and a greater fall in savings rate: hence, 
they project private consumption to remain flat through 2011. On this basis, they project growth to reach $1 \frac{3}{4}$ percent in 2011 .

\section{Looking further ahead, the pace of economic recovery is likely to be modest.} Compared to 6 percent over 2000-07, in the baseline program scenario, growth would average $23 / 4$ percent over $2012-15$. Even this modest recovery is subject to downside risks.

- $\quad$ Exports will continue to lead the recovery helped by improved competitiveness and world trade growth. However, spillovers from the largely enclave exports sector to the domestic economy will be limited because of their heavy reliance on imports, their tendency to employ capitalintensive processes, and the sizeable repatriation of profits generated by multinational exporters. But to the extent that the domestic sector participates in the export recovery - and signs of this are emerging as traditional sectors exports are picking up - the spillover to

Domestic demand has fallen sharply and is likely to take time to recover

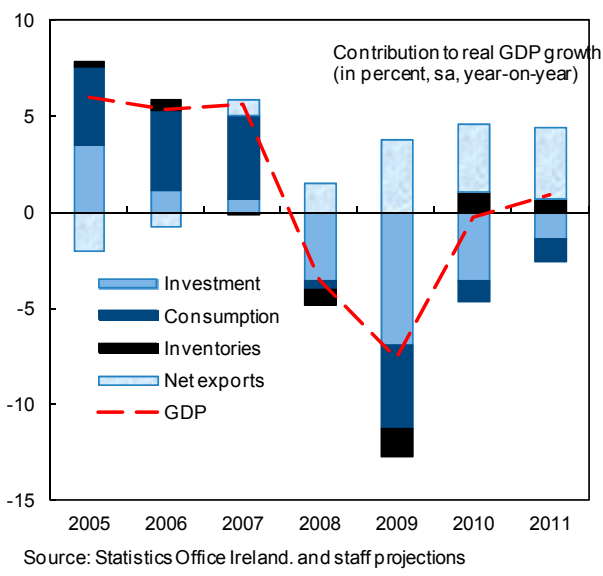

domestic demand could be greater.

- $\quad$ The large fiscal adjustment will remain a drag on consumption, as will the unwinding of home-grown imbalances from the boom yearsleading to weak credit growth, continued weakness in property prices and wages, and high real debt burdens. A sizeable structural component will likely keep the unemployment rate above 10 percent to 2015 .

- $\quad$ Private investment could bottom out at 7 percent of GDP in 2010, compared to a historical

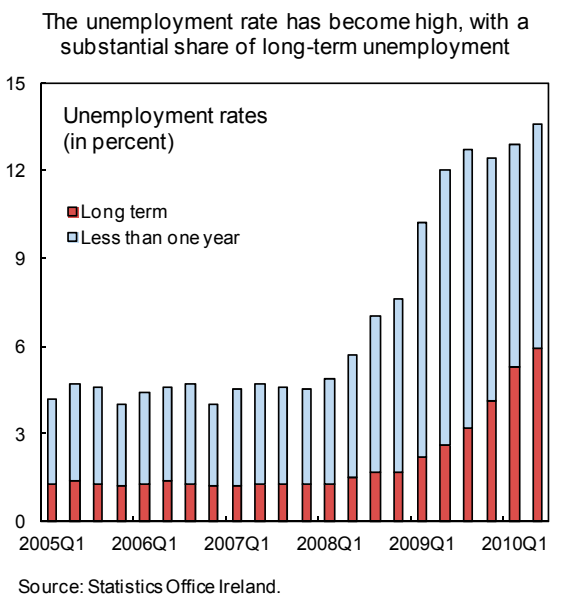
average of 20 percent. While lower public spending will keep investment low, with the recovery of exports and the normalization of domestic demand, a modest rebound is expected in the private investment ratio to 10 percent of GDP by 2015.

14. The authorities share staff's view on the pattern of the recovery, but are somewhat more optimistic about the magnitudes. The divergence from staff's projections continues through 2012 and then narrows in subsequent years. Again, the authorities see a larger scope for a fall in the private savings rate, as consumer confidence returns and labor market conditions improve. 


\section{Subdued inflation, below the euro-area average, will help competitiveness but} act as a short-term drag on the recovery. Staff and the authorities agree that with substantial spare capacity in the economy and modest external price pressures, inflation rates are expected to be low over the coming years. However, with a continued contraction in consumer spending in 2011, staff projects a further fall in consumer prices of $1 / 2$ percent. The authorities noted that exchange rate movements and energy price increase would prevent further price falls in 2011. Wage incomes fell on an annual basis by $2 \frac{1}{2}$ percent in the first half of 2010, and, looking ahead, are expected to increase more slowly than prices in the medium term, generating a real wage adjustment.
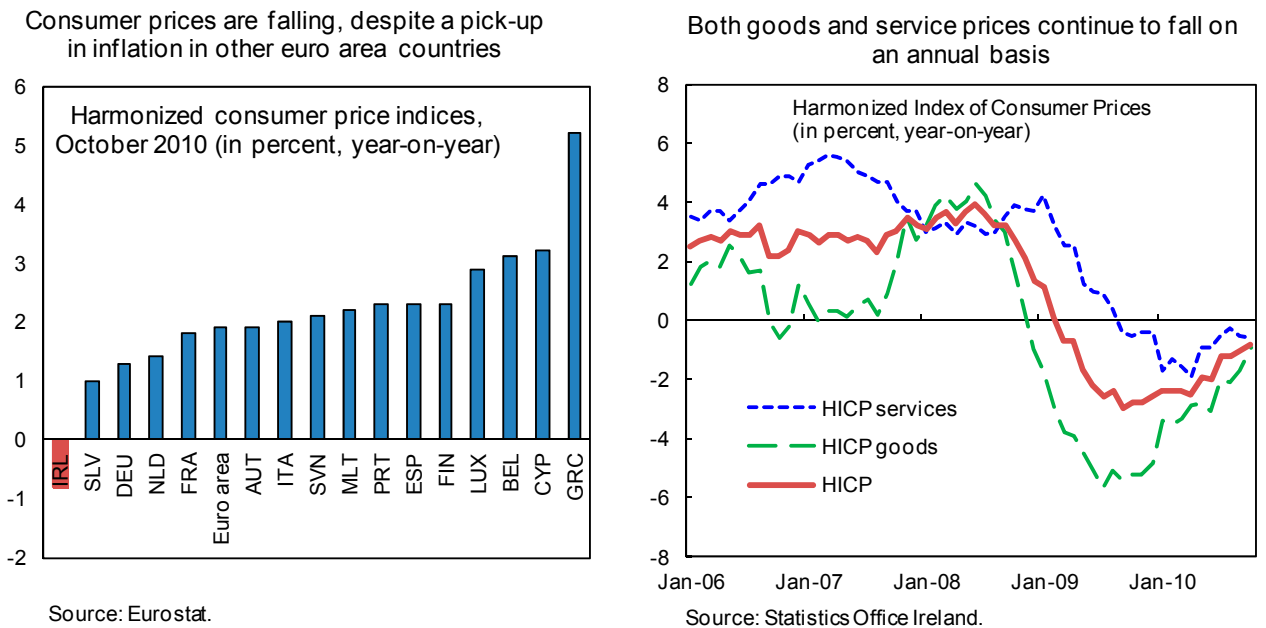

\section{Staff expects that the positive impact on the current account of higher net} exports will be partly offset by profits repatriation by multinational companies. The current account deficit has fallen sharply from 5 $\frac{1}{2}$ percent of GDP in 2008 to 2 percent in 2010, largely reflecting a correction of the boom in domestic demand. Going forward, the correction is expected to continue as net exports lead the recovery. However, since much of Ireland's exports are produced by multinationals, for which the value-added is to a large extent repatriated, factor income outflows will dampen the current account improvement. Furthermore, with high government and private sector debt, which is to a large extent held by foreigners and carries elevated interest rates, debt interest payments will represent a substantial current account outflow. 


\begin{tabular}{|c|c|c|c|c|c|c|c|}
\hline \multicolumn{8}{|c|}{$\begin{array}{l}\text { Ireland - Macroeconomic Projections } \\
\text { (Percentage change, unless otherwise indicated) }\end{array}$} \\
\hline & 2009 & 2010 & 2011 & 2012 & 2013 & 2014 & 2015 \\
\hline Real GDP & -7.6 & -0.2 & 0.9 & 1.9 & 2.4 & 3.0 & 3.4 \\
\hline Real domestic demand & -13.9 & -4.1 & -2.2 & 0.5 & 1.2 & 1.9 & 2.9 \\
\hline Private consumption & -7.0 & -1.4 & -1.0 & 0.5 & 1.2 & 1.5 & 2.2 \\
\hline Public consumption & -4.4 & -2.0 & -4.0 & -1.8 & -1.5 & -1.5 & 0.0 \\
\hline Fixed investment & -31.0 & -21.1 & -10.4 & 3.5 & 5.0 & 8.0 & 9.0 \\
\hline Change in stocks $1 /$ & -1.4 & 1.1 & 0.8 & 0.0 & 0.0 & 0.0 & 0.0 \\
\hline Net exports $1 /$ & 3.8 & 3.5 & 3.7 & 1.5 & 1.5 & 1.5 & 1.2 \\
\hline Exports & -4.1 & 5.8 & 4.5 & 4.5 & 4.6 & 4.7 & 4.7 \\
\hline Imports & -9.7 & 2.2 & 0.7 & 3.7 & 4.0 & 4.1 & 4.6 \\
\hline Current account (in percent of GDP) & -3.0 & -2.4 & -1.2 & -0.2 & -0.4 & -0.5 & -0.5 \\
\hline Consumer Prices (HICP) & -1.7 & -1.6 & -0.5 & 0.2 & 1.3 & 1.3 & 1.7 \\
\hline Unemployment rate (in percent) & 11.8 & 13.5 & 13.5 & 12.8 & 12.3 & 11.5 & 10.7 \\
\hline
\end{tabular}

\section{RETURning The BANKING System to HeAlthy FunCtionality}

\section{Banking sector vulnerabilities are concentrated in three key areas:}

- Low asset quality. The oversized domestic banks (text figure) are heavily exposed to the Irish property market, which has yet to stabilize. In September 2010, nonperforming loans were 12.9 percent of all loans and this ratio is expected to rise. Given the high levels of unemployment, cuts in real wages, and the heavy exposure to "tracker" and variable interest rate mortgages, investors are concerned that there may be unaddressed losses on non-NAMA assets, especially in residential mortgage lending (25 percent of private sector credit). Although official estimates suggest that only 10 percent of residential mortgages are either in arrears or have been rescheduled, banks' loan portfolios might be impacted by a high level of forbearance (Box 5). Provisioning levels have also declined sharply in recent years (offset in part by bolstered capital). Finally, current low policy rates will, when raised, exert considerable pressure on variable rate mortgage holders.

- Constant funding concerns. The cliff effect of maturing loans in last quarter of 2010 following the expiry of the original CIFS guarantee, uncertainties about the renewal of guarantees, and concerns about restructuring strategies of unsecured creditors have escalated problems with rolling over large wholesale funding needs.

- $\quad$ Prolonged Anglo-Irish bank resolution. Although the bank was nationalized almost two years ago, it has sucked in ever-increasing public funds, and has served as a nagging reminder of the severe banking supervision deficiencies in Ireland and the poor state of Irish banks. 
The size of the domestic banking system became excessive during the boom..

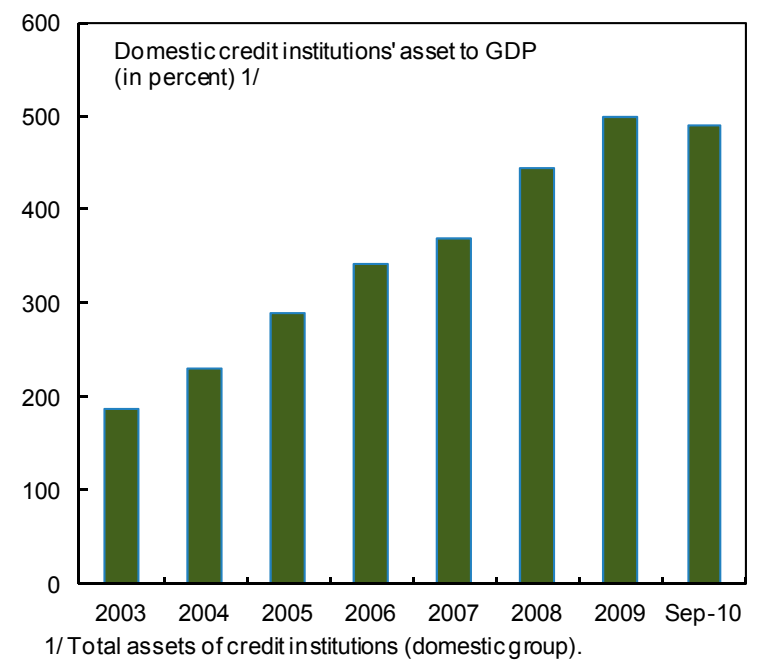

Bank regulatory capital has fallen...

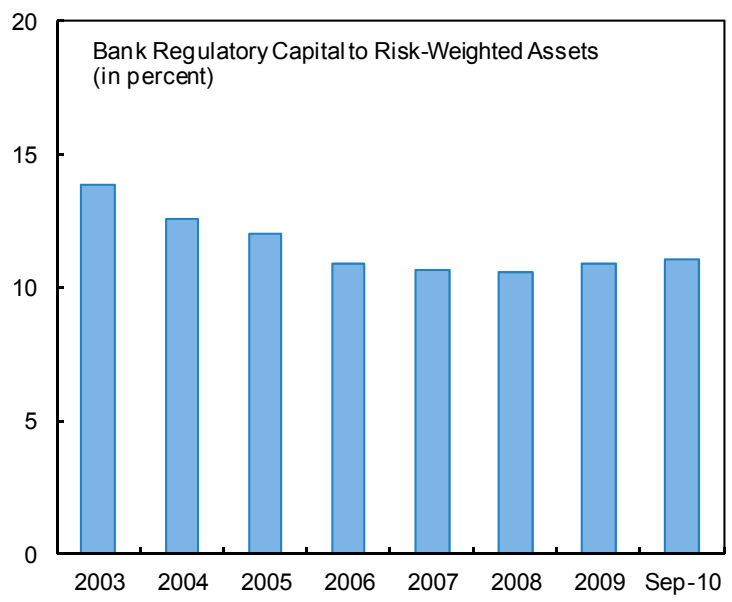

In the past year, banks' non-performing loans increased dramatically...

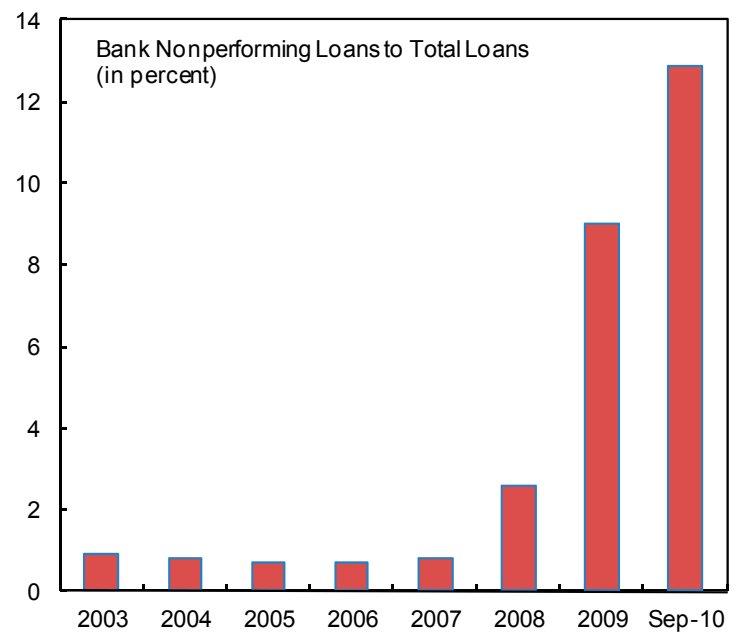

.. with the share of real estate loans to total loans doubling in four years

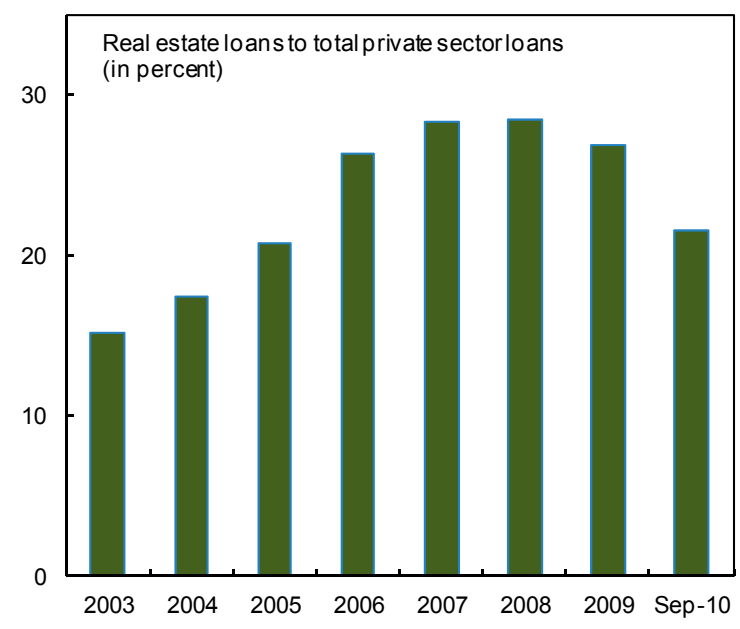

... and the loan to deposit ratio has increased to a high level

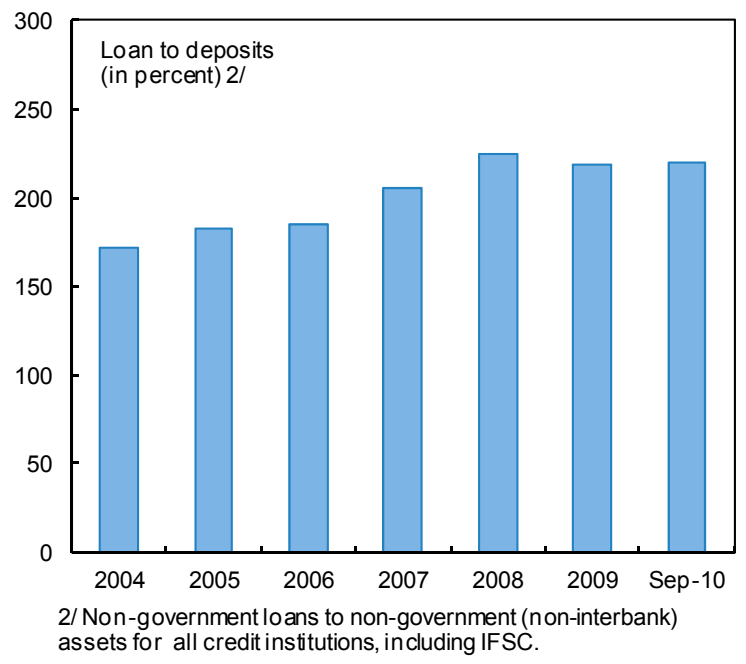

... while bank provisioning to non-performing loans is declining

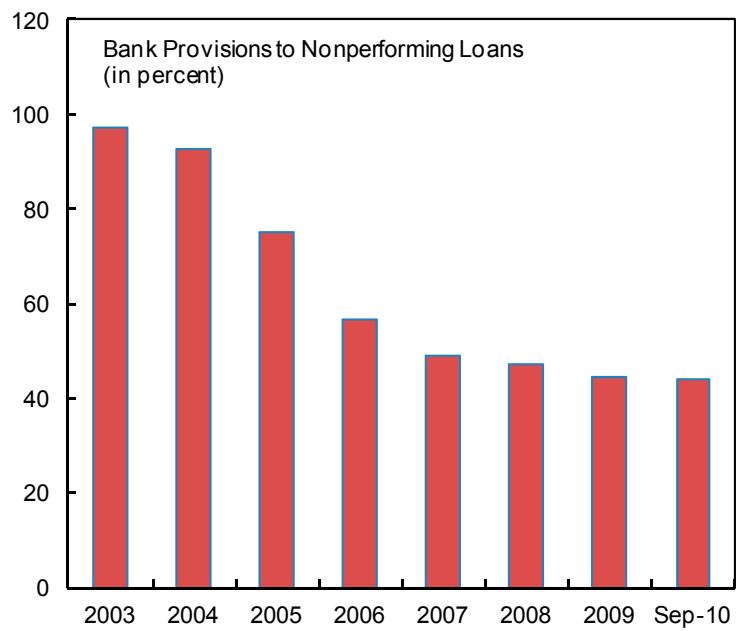

Source: Central Bank of Ireland. 
18. In this context, the authorities and staff agreed that a comprehensive bank

restructuring program is critical. There was a shared view that the objectives of this process would be to:

- Isolate the viable banks and return them to healthy functionality by substantial downsizing and reorganization.

- $\quad$ Support the transition to a downsized banking sector through recapitalization to reduce perceptions of weakness and encourage deposit inflows and market-based funding.

- $\quad$ Reduce systemic risk and increase shock-absorbing capacity through stronger supervision and a special resolution regime for banks.

\section{A. Downsizing and Reorganization}

19. Comprehensive measures were agreed to achieve a substantial downsizing of the banking system over time. Banks will start taking several actions as they will be required to:

- Unwind noncore assets (including operations abroad).

- Quickly transfer the remaining vulnerable assets (land property and development loans) to NAMA (about $€ 17$ billion). This would require amendment to existing legislation to permit the transfer of assets in a block rather than on individual basis as presently required by law. Alternatively, the authorities are also considering speeding up the process to allow immediate asset transfers to NAMA at the current average haircut and then adjusting the price through ex-post single valuation.

- $\quad$ Promptly and fully provision for all nonperforming assets as needed.

- $\quad$ Deleverage additional specified portfolios as feasible, supported by credit enhancements. For example, particular portfolios of assets could be packaged for clean sale to third parties (i.e., not a government sponsored entity).

- $\quad$ Distressed institutions, including Anglo-Irish Bank and Irish Nationwide Building Society will be resolved without compromising the interests of protected or secured creditors.

To ensure progress made, banks will be required to submit business plans demonstrating their explicit commitment to deleverage and restructure operations through clear periodical targets, which will be defined on the basis of criteria developed by the central bank in consultation with the EC, ECB and IMF. 


\section{B. Raising Capital Standards}

20. The transition to a leaner and more robust system is to be navigated by setting higher capital standards and ensuring availability of financing to achieve them. In this regard, the following strategy is planned:

- $\quad$ Promptly increase capital buffers. The central bank will enforce recapitalization of viable banks to achieve a capital ratio of 12 percent Core Tier 1 by endFebruary 2011. ${ }^{3}$

- Stringent forward-looking assessment of capital needs. Stress-tests based on adverse scenarios (PCAR 2011) and a diagnostic of current asset valuations (Boxes 3 and 4) will be initiated to thoroughly review the capital needs of banks over a horizon of three years. All key details of these new stress tests will be communicated transparently to enable market participants to assess the results. Following this assessment, a capital ratio of 10.5 percent Core Tier 1 would become the new regulatory minimum. This ratio would place the banks in the league of wellcapitalized peers and would be a move towards Basel III standards.

- Taking into account the overall resources available to the authorities, including from the EU-IMF financing, the authorities will have adequate funds to meet needed recapitalization. Under the program, the authorities have a notional buffer of about $€ 35$ billion to support the banking system. The actual amount used is expected to be less than this buffer. In the first instance, up to $€ 10$ billion would ensure the immediate recapitalization of banks up to 12 percent in Core Tier I capital and the remaining $€ 25$ billion would be available on a contingency basis to maintain a capital ratio of 10.5 percent of Core Tier I capital under a stress scenario.

21. Banks' funding risk is currently alleviated by the extension of the government guarantee until December 2011, but markets may require a longer period of security. The ECB has endorsed the authorities' view that extending the guarantee is needed for financial stability purposes and the EC has agreed that stability would be given precedence over competition considerations. Currently, the extension has been approved by the European Commission through the end of June 2011. The need for further extension of the guarantee, perhaps on a more limited basis, will need to be assessed in due course. The strengthening of banks' balance sheets under the program would also facilitate Eurosystem liquidity support for banks with improved solvency prospects and collateral.

\footnotetext{
${ }^{3}$ Irish Life and Permanent would need to reach the capital ratio by May 2011.
} 


\section{Box 3. Methodology to Conduct a Second Stress Test Exercise (PCAR 2011)}

Phases: The stress test will take place in two phases. The first stage, planned to be completed by the end of March 2011, will involve the 6 largest domestic banks. Credit unions and subsidiaries of foreign banks will be considered in the second phase, planned to be completed by the end of June 2011.

Definition of parameters and scenarios. The central bank will define the detailed criteria to run the revised stress test by end-December 2010, in consultation with EC, ECB, and IMF staff. Staff and the authorities have agreed to include interest rate and exchange rate risks as additional criteria to ensure banks will hold sufficient capital to absorb losses stemming from banks' maturity gaps.

Capital targets. Banks will have to meet a minimum Core Tier 1 ratio of 10.5 percent under the baseline scenario (compared to the 8 percent under PCAR 2010) and a minimum Core Tier 1 ratio of 6 percent under the stress scenario (compared to 4 percent under PCAR 2010). The time horizon of the exercise will be 2011-13.

Approach. The stress-test will include a top-down component and a bottom-up component. The top-down component will consist of a macroeconomic scenario developed by the Irish central bank aimed to be consistent with the EU-wide stress test conducted by CEBS/EBA, with additional specifications to adapt the framework to the local economic conditions including, as feasible, taking into account special features of the credit union model. The bottom-up analysis will also include targeted loan reviews, benchmarking of collateral valuations, reviewing provisioning methodologies and approaches to workout/liquidation. The final assessment will be based on the most conservative results from the top-down and bottomup approaches.

Probability of default. The probability of default for different portfolios and loss given default will be estimated based on both the top-down and the bottom-up components of the stress test.

Liquidity risk. The exercise will review the funding mix and related costs, also through benchmarking across institutions. An analysis of the impact of possibly higher funding costs will be carried out by the authorities. In this context, elements such as credit rating downgrades, contingent liabilities management, contingency funding plans, impact of divestments and restructuring will form part of the analysis.

Transparency on results. Disclosure of the final results and methodology are important elements to enhance market confidence about the robustness and comprehensiveness of the overall exercise. Proper communication of any needed related action would also need to be addressed. 


\section{Box 4. Initial Terms of Reference for Data Quality and Asset Quality Diagnostic Review}

Objective: Support the new PCAR with a thorough and in depth due diligence of the integrity of the banks' financial reporting and the quality of banks' assets.

Principles. The exercises will be conducted in line with four principles: (i) the diagnostic study should not be conducted by an audit or consultancy firm that has provided such services to the bank in the last three years. The central bank should also contract a specialized firm to help staff to oversee the consistency and integrity of the exercise; (ii) these examinations should cover all relevant assets, liabilities and off balance sheet items, including foreign subsidiaries when relevant. They should provide a thorough assessment of the adequacy of monitoring and reporting of all relevant risks (credit, market, foreign exchange, liquidity and operational risks); (iii) strict benchmarks should be used similar to those regularly used to assure the quality of the due diligence processes; and (iv) to ensure transparency, the third party independent reports should be made public on the website of each individual institution as well as on that of the central banks as soon as the PCAR 2011 process is completed.

\section{General scope and benchmarks of the review}

\section{Data validation}

The validation process would seek to ensure that data is properly compiled, processed and reported. In particular, this exercise will verify the integrity of the banks' internal process in the following fronts: (i) information technology, (ii) accounting of earnings; and (iii) reporting and disclosures.

The review should be comprehensive and conducted on the basis of internationally accepted methodologies. It should adequately cover bank's activities (assets, liabilities, off-balance sheet, and reporting of bank risks) including those of their subsidiaries and affiliates.

\section{Asset quality validation}

This component includes an assessment of asset quality in accordance with a methodology that seeks to identify the recoverable value of assets through the economic cycle, in net present value terms.

The asset diagnostic process would assess the quality of assets and the effect on the bank's capital of any related adjustment. It would cover not only loans but all other material exposures of banks' (on and off-balance sheet) and their investment portfolios.

Review of terms of reference and asset valuation methodology. The development of the terms of reference by the central bank and of the asset valuation methodology by the consulting firms will be carried out in consultation with EC, ECB and IMF staff.

Reporting and disclosure. The assessors' report should provide to the central bank (i) a factual summary of their findings and recommendations to address existing operational and data integrity weaknesses; (ii) the necessary adjustment based on the verification process and the effect of these adjustments on the bank's reported regulatory capital. The main findings will also be made public. 


\section{Reducing Risk and Increasing Shock Absorption Capacity}

\section{Steps are also being taken to address institutional weaknesses that were} uncovered at the onset of the crisis. They will contribute to make the overall financial system more robust:

- $\quad$ The government remains firmly committed to strengthening banking supervision, a critical failing in the lead up to the crisis. Staffing levels and budget allocations will be substantially increased. Top level management at the supervisory authority has been changed. In addition, the authorities have announced an enhanced risk assessment framework, strict corporate governance standards, and the reorganization of the supervisory board structure. An independent assessor will take stock of progress as well as compliance with Basel Core Principles for effective banking supervision.

- $\quad$ The authorities are preparing legislation to establish a comprehensive bank resolution framework, drawing on proposals under discussion at the European level and recent legislative reforms such as in the U.K. and Germany. The authorities share staff's view that broader resolution tools with stronger powers for the central bank will enhance their ability to deal with distressed institutions in future. In particular, the draft legislation will provide for the appointment of special managers to perform the function of senior management and the bank's board, the ability to transfer assets and liabilities, and the establishment of bridge banks. Further, the new regime needs to be linked with the liquidation framework.

- $\quad$ The personal insolvency regime will be substantially reformed. Despite steps taken to eliminate some of the rigidities in the current court-based bankruptcy framework by reducing the discharge period from 12 to six years (at the court's discretion), the authorities agree that broader legal reform is needed. Once the Law Reform Commission has presented its final report in December 2010 legislative drafting will commence as a matter of priority. The reforms could include the establishment of a new debt enforcement office to administer an alternative non-judicial debt settlement and enforcement mechanism, while minimizing moral hazard. The authorities estimate that initial uptake of the improved in-court and new non-judicial proceedings will be significant given the extent of household financial distress. 


\section{Box 5. Ireland-Residential Mortgages}

Irish households are increasingly under pressure to meet their residential mortgage and other debt obligations. Current central bank data indicates that about 40,000 residential mortgages (close to 5.1 percent) are in arrears. Moreover, it is estimated that about 45,000 mortgages have been rescheduled under a voluntary scheme so far, bringing the total of mortgages in distress to more than 70,000, given the overlap between the two categories. The number of mortgages in arrears has been rising steadily, fueled by high unemployment and growing economic stress on households.

Interest rates for "tracker" mortgages linked to the ECB main refinancing rate remain low, but additional pressure may arise should this interest rate increase. About half of the banks' residential mortgage book are "tracker" mortgages, most of which were originated since 2006. Many mortgages for investment properties are also "tracker" mortgages now reaching thresholds that require the repayment of principal (following interest-only periods during the first five years). Given the significant fall in real estate values, many households are also faced with negative equity, thereby limiting mobility. First time buyers who bought at the height of the real estate boom in 2006/2007 are particularly vulnerable.

Mortgage restructurings are guided by the Central Bank's Code of Conduct on Mortgage Arrears and the Irish Banking Federation's voluntary Operational Protocol. The Code of Conduct applies to mortgages on the principal private residence and sets out a restructuring framework for borrowers unable to pay (mostly in the form of a rescheduling), including a moratorium on repossession for 12 months. The Code of Conduct is currently under revision to strengthen procedural protections and is expected to be issued shortly. Under the Operational Protocol, banks are encouraged to reach agreement with borrowers on an affordable and sustainable repayment plan, often assisted by a Money Advice and Budgeting Service advisor (state-funded debt advisory service).

Several financial support programs are in place to assist homeowners, though these should only target the neediest. Mortgage interest supplement (MIS) provides short-term support during periods of unemployment or reduced income and the number of recipients has more than doubled since 2008 to 17,800 in November 2010. MIS appears to facilitate rescheduling arrangements to "interest only" repayment plans. The authorities intend to centralize the administration of MIS to ensure more consistent application of relevant ceilings. Further, the authorities grant mortgage interest tax relief for recent vintage mortgages and affordable housing support by local authorities.

Acknowledging that further measures are necessary, while limiting moral hazard, the authorities seek to implement some of the measures recommended by an expert group. The final report by the Mortgage Arrears and Personal Debt Group recommends the introduction of a Deferred Interest Scheme (DIS) for mortgages deemed sustainable. The DIS would allow the deferral of up to one third of interest payments for up to five years or when 18 months deferred interest has accrued, whichever comes sooner, with no interest accruing on the deferred interest portion. Unsustainable cases would require trading down or voluntary surrender of the residence. However, should more households seek access to social housing the demand will likely exceed supply. Moreover, given the extent of household distress and the remaining personal liability for any mortgage amounts not recovered in a foreclosure proceeding, it seems essential to develop a comprehensive personal insolvency regime, a step also under consideration by the authorities. 


\section{Safeguarding Public Finances}

\section{From the onset of the crisis, the authorities took strong fiscal adjustment}

measures to address debt sustainability

concerns. The structural deficit, adjusted for the impact of asset prices, reached 12 percent of GDP in 2008. As the financial crisis unveiled Ireland's large underlying imbalances, the authorities immediately implemented large deficit-reducing measures and set out strong medium-term consolidation targets. Overall, the measures implemented during 2009-10 — a time when most Euro zone countries were providing fiscal stimulus - amounted to 6.3 percent of GDP (8 percent of GDP in full year terms).

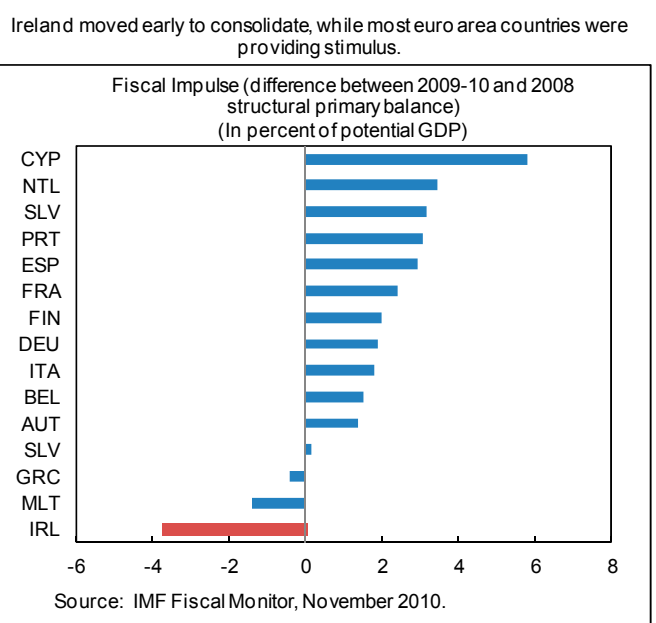

24. Weak growth and banking distress have, however, placed a greater burden on public finances than previously anticipated. Large, post-boom deficits and major bank support have added substantially to the debt stock, leading the government to rightly conclude that additional deep fiscal consolidation is critical.

\section{A. Consolidation Strategy}

25. The program aims to preserve fiscal sustainability while mitigating adverse effects on growth. The planned consolidation over 2011-14, laid out in the authorities' National Recovery Plan, is broadly appropriate. However, staff expects GDP growth outcomes to be weaker than those currently foreseen by the authorities and hence the deficit ratio to fall more slowly than envisaged under the plan. Reflecting this reality, the European Commission recently extended by one year the deadline for meeting the Stability and Growth Pact deficit threshold of 3 percent of GDP to 2015. This helps defer the authorities' obligations to the Stability and Growth Pact. However, under staff's current projections, achieving the new target is likely to need further measures in the medium term.

\begin{tabular}{lrrrrrrrrr}
\multicolumn{1}{c}{$\begin{array}{c}\text { General Government Finances 1/ } \\
\text { (In percent of GDP) }\end{array}$} \\
\hline & \multicolumn{7}{c}{ Actual } & \multicolumn{1}{c}{ Staff projections } \\
\cline { 2 - 11 } & 2007 & 2008 & 2009 & 2010 & 2011 & 2012 & 2013 & 2014 & 2015 \\
\hline General government balance & 0.1 & -7.3 & -14.4 & -32.0 & -10.5 & -8.6 & -7.5 & -5.1 & -4.8 \\
Current revenue & 34.6 & 33.3 & 33.1 & 33.4 & 34.0 & 34.5 & 34.9 & 35.4 & 35.6 \\
Current expenditure & 29.9 & 34.4 & 40.8 & 41.7 & 41.3 & 40.3 & 40.0 & 38.2 & 38.1 \\
Capital balance & -4.7 & -6.2 & -6.8 & -23.8 & -3.2 & -2.8 & -2.5 & -2.3 & -2.3 \\
Primary balance & 0.9 & -6.3 & -12.3 & -29.0 & -6.7 & -4.1 & -1.4 & 1.2 & 1.5 \\
Primary balance excl. bank support & 0.9 & -6.3 & -9.7 & -9.6 & -6.7 & -4.1 & -1.4 & 1.2 & 1.5 \\
General government gross debt & 25.0 & 44.4 & 65.6 & 98.9 & 112.8 & 120.0 & 124.5 & 124.1 & 123.0 \\
\hline
\end{tabular}

Sources: Department of Finance and staff estimates.

1/ The general government numbers fully incorporate IMF/EFSF financing, including bank recapitalization under the program. 


\section{The envisaged consolidation is necessary to put the debt-to-GDP ratio on a}

downward path. The combination of low growth and inflation, and a high fiscal deficit are likely to continue to push up the debt ratio in the coming few years. However, the comprehensive structural measures under the program will yield a permanent reduction in spending and a more stable revenue base in the medium term. The debt ratio is expected to start declining by 2014 on account of an improvement in the structural primary balance (by more than 8 percent of GDP between 2010 and 2015) and the convergence of nominal GDP growth rates to the implied average interest rate on

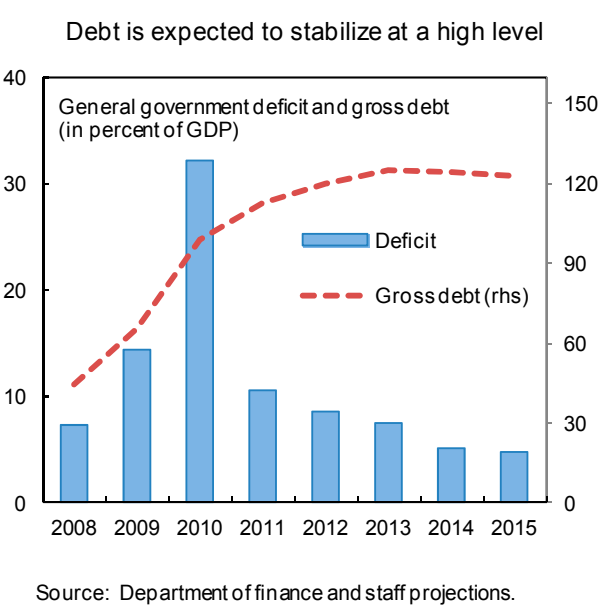
public debt.

\section{Debt dynamics would improve if the recapitalization requirement remains} contained. Staff estimates suggest that it is unlikely that bank capitalization needs will exceed $€ 35$ billion. If that amount is needed, the authorities would use their own resources of up to $€ 17.5$ billion and $€ 17.5$ billion would be added to sovereign debt. In this conservative baseline scenario, the debt ratio would peak at 125 percent of GDP in 2013. If the needs are lower, as is currently anticipated, less financing under the overall program will be required. In this case, the government can use its liquid assets to cover the budgetary financing needs, also reducing the debt. In a scenario where capitalization needs are $€ 25$ billion, debt would

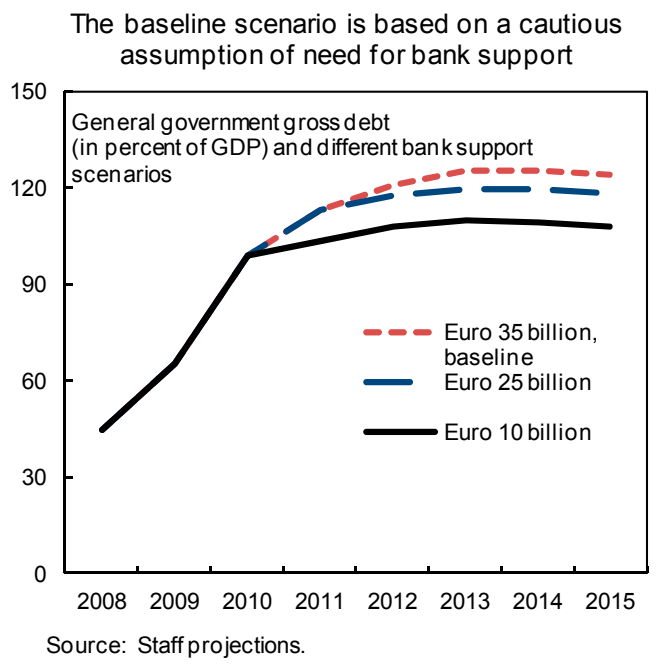
peak at 119 percent of GDP in 2013, and if only the initial $€ 10$ billion is required, debt would peak at 109 percent of GDP.

\section{The sovereign's obligations will also be lower if the debt owed by banks is}

restructured. For Anglo Irish, which is a nationalized bank, a debt exchange at a discount of about 80 percent is ongoing. This operation reflects the view that subordinated debt is designed to be loss absorbing and where a bank has lost substantial value - and, indeed, insolvent - the debt holders should share in the losses. Further such action is contemplated for banks that have received substantial state assistance, and would help reduce the need for fresh injections of capital by the government. Both the authorities and the staff noted that the decision to share losses with creditors should, in principle, be based on the extent of the banks' overall losses and the need to return the bank to a more stable funding structure, while keeping in view the knock-on effects on others. 


\section{B. The National Recovery Plan and Program Targets}

\section{The authorities' National Recovery Plan forms the basis of the fiscal program.}

The plan provides for $€ 15$ billion ( 9 percent of GDP) in budgetary savings over 2011-14, almost twice the level envisaged in the December 2009 Stability and Growth Pact Update. The adjustment is front-loaded - with $€ 6$ billion (3.5 percent of GDP) in savings expected in 2011 alone, and focused on expenditure reductions, which account for about two-thirds of the effort through 2014.

\section{Budget 2011, including adjustment} measures of $€ 6$ billion, is set for parliamentary approval on December 7. Although about $€ 0.7$ billion worth of measures are of a one-off nature, and despite the reliance on capital expenditure cuts in 2011, the measures are broadly durable and of high quality. One-third of the

The consolidation is front-loaded and expenditure-based

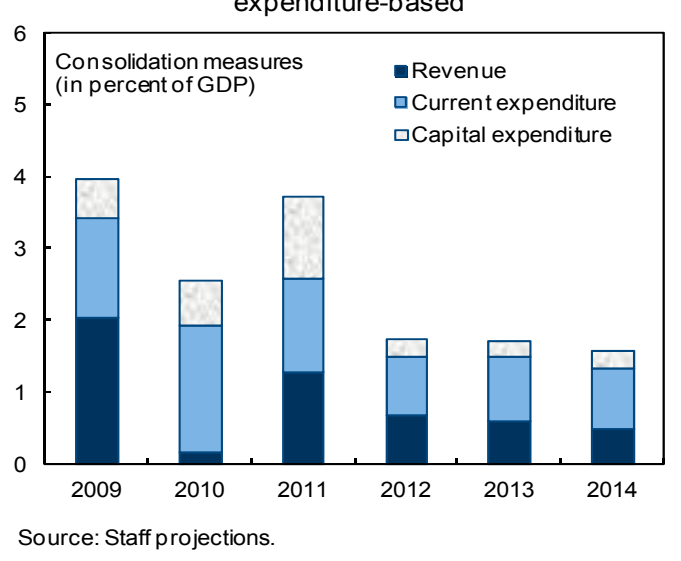
adjustment ( $€ 1.8$ billion) will come from capital spending, including due to better value-formoney infrastructure procurements. The current spending effort will be led by savings of $€ 1.2$ billion in payroll and discretionary expenditure, reflecting (voluntary) public service numbers reductions of about 8,000 ( $21 / 4$ percent of the payroll); a 10 percent salary reduction for new entrants; an average 4 percent cut in public service pensions, graduated according to pension level; and other efficiency savings. ${ }^{4}$ On social welfare, the authorities intend to reduce universal and, hence, nonprogressive benefits, and reform working age payments and associated job search conditionality to lower the risk of poverty and inactivity traps for the long-term unemployed. These measures are expected to yield $€ 0.9$ billion, about one-sixth of the planned 2011 consolidation. As such, the adjustment takes due regard of Ireland's strong system of social protection.

\section{A revenue package—-sized at $€ 1.4$ billion—widens the base for income tax and} raises its progressivity. Through a 10 percent reduction in personal income tax bands and credits, and an integration of the health and income levies, budget 2011 will seek a positive contribution from part of the 45 percent of households that were hitherto exempt from income tax, while removing non-progressive exemptions enjoyed by certain groups. The remaining measures will build on the progressive packages already implemented in 2009-10. In particular, the authorities intend, inter alia, to withdraw various tax reliefs on private pension contributions, lower the tax-allowable ceiling for such contributions, eliminate other

\footnotetext{
${ }^{4}$ The authorities have indicated in the plan that their commitments with regard to pay rates and job security through 2014 under the Croke Park Agreement are dependent on the realization of the promised efficiency savings in the Agreement and achievement of the voluntary public service reductions.
} 
income tax expenditures, and further strengthen capital taxation. These include the withdrawal of various tax reliefs on private pension contributions, a lowering of the taxallowable ceiling for such contributions.

32. The 2011 program targets allow accommodation of risks to growth. Staff and the authorities agreed that the traditional budgetary aggregate - the exchequer balance (excluding net interest payments and costs arising from bank support operations in the context of the program) should serve as the performance criterion. The authorities were confident about meeting the end-2010 target, based on revenue and expenditure outturns through November. For 2011, the targets are derived from the measures approved in budget 2011 and staff's macroeconomic projection. If growth is lower than projected by staff, the program does not require spending cuts to offset underperformance from prudent revenue projections, which would otherwise further weaken demand. In parallel, and to secure debt sustainability, the program requires that any revenue over-performance be saved. It will be critical that the tax administration has continued adequate funding and technical capacity to effectively implement the planned tax policy changes and counteract lower compliance pressures due to the recession.

\begin{tabular}{|c|c|c|c|c|}
\hline \multicolumn{5}{|c|}{$\begin{array}{l}\text { Fiscal Consolidation Measures in } 2009-10 \text { and in the National Recovery Plan } \\
\text { (Announced net yields in } € \text { billions, relative to pre-budget positions) }\end{array}$} \\
\hline & & $2009-10$ & & 2011-14 \\
\hline Total & \multicolumn{2}{|c|}{$€ 10.4$ bn ( 6.3 percent of GDP) } & \multicolumn{2}{|c|}{$€ 15.0$ bn ( 9.4 percent of GDP) } \\
\hline Revenue & \multicolumn{2}{|c|}{$€ 3.6$ bn ( 2.1 percent of GDP) } & \multicolumn{2}{|c|}{$€ 5.1$ bn ( 3.2 percent of GDP) } \\
\hline $\begin{array}{l}\text { Direct taxes } \\
\text { (taxes on income and } \\
\text { wealth) }\end{array}$ & 3.1 & $\begin{array}{l}\text { Introduction and doubling of income levy (base- } \\
\text { broadening). Increased capital taxation } \\
\text { (progressive). Tightening of mortgage interest relief } \\
\text { (progressive/efficiency). }\end{array}$ & 4.1 & $\begin{array}{l}16.5 \text { percent lowering of bands and credits, of which } 10 \text { percent in } 2011 \\
\text { (base-broadening). Withdrawal of tax reliefs on private pension } \\
\text { contributions (progressive/base-broadening). Tightening of tax expenditures } \\
\text { (base-broadening/efficieny). Site value-based property tax in } 2014 \text { (building } \\
\text { stable revenue source for LGs). }\end{array}$ \\
\hline $\begin{array}{l}\text { Indirect taxation } \\
\text { (VAT, excise and } \\
\text { carbon taxes) }\end{array}$ & 0.5 & $\begin{array}{l}\text { Carbon tax of } € 15 / \text { tonne on fossil fuels } \\
\text { (environmental protection). Increased rates on } \\
\text { mineral oil, cigarettes, liquor (equity; efficiency). New } \\
\text { air travel tax (progressivity). VAT rate raised from } \\
21 \% \text { to } 21.5 \% \text { but reversed. }\end{array}$ & 1.0 & $\begin{array}{l}\text { Increase in carbon tax to } € 25 \text { in } 2012 \text { and to } € 30 \text { in } 2014 \text { (environmental } \\
\text { protection). Increase in VAT rate to } 22 \text { percent in } 2013 \text { and } 23 \text { percent in } \\
2014 \text { (consumption forward-shifting). Removal of tax subsidies implied by } \\
\text { lower VAT rates (efficiency/base broadening). }\end{array}$ \\
\hline Expenditure & \multicolumn{2}{|c|}{$€ 6.8$ bn (4.2 percent of GDP) } & \multicolumn{2}{|c|}{$€ 9.9$ bn ( 6.2 percent of GDP) } \\
\hline Current spending & \multicolumn{2}{|l|}{5.0} & \multicolumn{2}{|l|}{6.9} \\
\hline Payroll & 2.2 & $\begin{array}{l}14 \text { percent graduated wage cuts for public servants } \\
\text { (fairness). Size of public service contained } \\
\text { (efficiency). }\end{array}$ & 1.2 & $\begin{array}{l}5 \text { percent reduction in public service numbers (via voluntary schemes and } \\
\text { attrition) and } 10 \text { percent cut in new recruit salaries (efficiency). } 4 \text { percent } \\
\text { graduated cut in public service pensions (fairness). }\end{array}$ \\
\hline Discretionary & 2.2 & $\begin{array}{l}\text { Lower payments to drug suppliers and faster } \\
\text { collection of private patient bills (efficiency); halving } \\
\text { of advertising, PR and consultancy budgets } \\
\text { (rationalization); reduced ODA (cost-cutting); early } \\
\text { childcare supplement eliminated in favor of free pre- } \\
\text { school year (cost-cutting/efficiency) }\end{array}$ & 2.9 & $\begin{array}{l}\text { Administrative efficiencies via flexibility in staff redeployment, e- } \\
\text { Government, streamlining of programs, performance budgeting and by- } \\
\text { vote ceilings through } 2014 \text { (efficiency/cost-cutting). Cost recovery on } \\
\text { provision of tertiary education, while protecting lower-income students } \\
\text { through means-tested loan scheme (efficiency/fairness). }\end{array}$ \\
\hline Social welfare & 0.6 & $\begin{array}{l}\text { Cut in child, maternity, adoption benefits and in } \\
\text { maximum welfare payments to elderly (cost- } \\
\text { cutting/fairness). Lower unemployment benefits for } \\
\text { young unemployed and where activation measures } \\
\text { refused (to generate labor supply response). }\end{array}$ & 2.8 & $\begin{array}{l}\text { Cuts in unemployment and related assistance/strengthened activation } \\
\text { measures (to induce labor supply response). Cuts in universal component } \\
\text { of child benefit in favor of means-tested support for families with children } \\
\text { (progressive). Reform of disability payments and introduction of single } \\
\text { means-tested social assistance payment for working age people } \\
\text { (equity/efficiency). }\end{array}$ \\
\hline Net capital spending & 1.8 & $\begin{array}{l}\text { Reprioritization of capital projects. Comprehensive } \\
\text { review of investment program (rationalization). }\end{array}$ & 3.0 & $\begin{array}{l}\text { Value-for-money in infrastructure procurements (efficiency). Metered water } \\
\text { charging to cover costs of provision of water services } \\
\text { (efficiency/equity/water conservation). }\end{array}$ \\
\hline
\end{tabular}


33. The plan details a number of high-quality fiscal measures over the medium term. A major reform on the revenue side is the planned introduction, by 2014, of a sitevalue tax on residential property that will provide a stable source of local government revenue. Indirect taxation is to be strengthened through phased increases in VAT and carbon tax rates, starting 2012-13, and a tightening of VAT subsidies. On the expenditure side, the plan envisages progress toward full cost-recovery in the provision of water services and tertiary education, while protecting lower-income groups through means-tested support schemes. Indicative ceilings by Vote Group have been set to anchor further efficiency savings in payroll, capital and discretionary current spending; while welfare reductions are expected to obtain via a reform of child and disability benefits, and the introduction of a single means-tested social assistance payment for working age people.

\section{In sum, the plan strikes a reasonable balance between several competing} considerations and thus provides a good basis for the fiscal program. First, the size and phasing of the package has resonated well with market anticipation of its debt reduction effect. Second, the inclusion of labor market activation measures is growth friendly and ameliorates concerns about the impact of the consolidation on domestic demand. Third, the plan achieves a suitable balance between equity and efficiency: proposed spending efficiencies of $€ 7.1$ billion are complemented by relatively progressive direct tax increases of $€ 4.1$ billion, while planned welfare cuts are focused on universal and employment-inhibiting benefits. Finally, the focus on expanding the tax base and cultivating new sources of revenue is appropriate given that volatile revenues were a key contributor to fiscal stress during the crisis.

\section{Institutional Reforms for Fiscal Sustainability}

35. To entrench fiscal credibility, the authorities are preparing a fiscal responsibility law (FRL). In line with staff's earlier advice, the law will provide for:

- A medium-term budgetary framework, including binding multi-year expenditure ceilings by department. A formal multi-annual budgetary framework enshrined in the FRL can lend greater credibility to these ceilings, and thus, reduce the uncertainties associated with consolidation.

- A fiscal institutional framework. To reinforce the commitment to sustainable public finances, the authorities will adopt a fiscal rule to provide a post-consolidation anchor for fiscal policies. Staff welcomed the proposal, and noted that the fiscal rule should have broad coverage and be easy to monitor. The authorities are also establishing a budget advisory council to assess fiscal policies and forecasts, and highlight longterm risks to public finances. These mechanisms would further enhance policy credibility. 
36. The authorities are planning to reform key pensions parameters to avert potential risks to long-term debt sustainability. Ireland's ageing-related spending profiles compare well vis-à-vis other OECD economies. However, the surge in spending on public service and state pensions in recent years has alerted the authorities to move early and decisively on this front. Consistent with the National Pensions Framework (published in March 2010), the authorities are planning to introduce legislation in 2011 to increase the pension retirement age from 65 to 66 by 2014, 67 by 2021, and to 68 by 2028. For new entrants into the public service, pension entitlements will be linked to average career earnings and annual increases indexed to consumer prices. Over the medium-term, the authorities also intend to review the indexation regime for state pensions.

\section{Projected Increases in Government Spending on Health and Spending are Low Relative to Advanced Economies}

(change in relevant expenditure in percentage points of GDP, 2010-30)
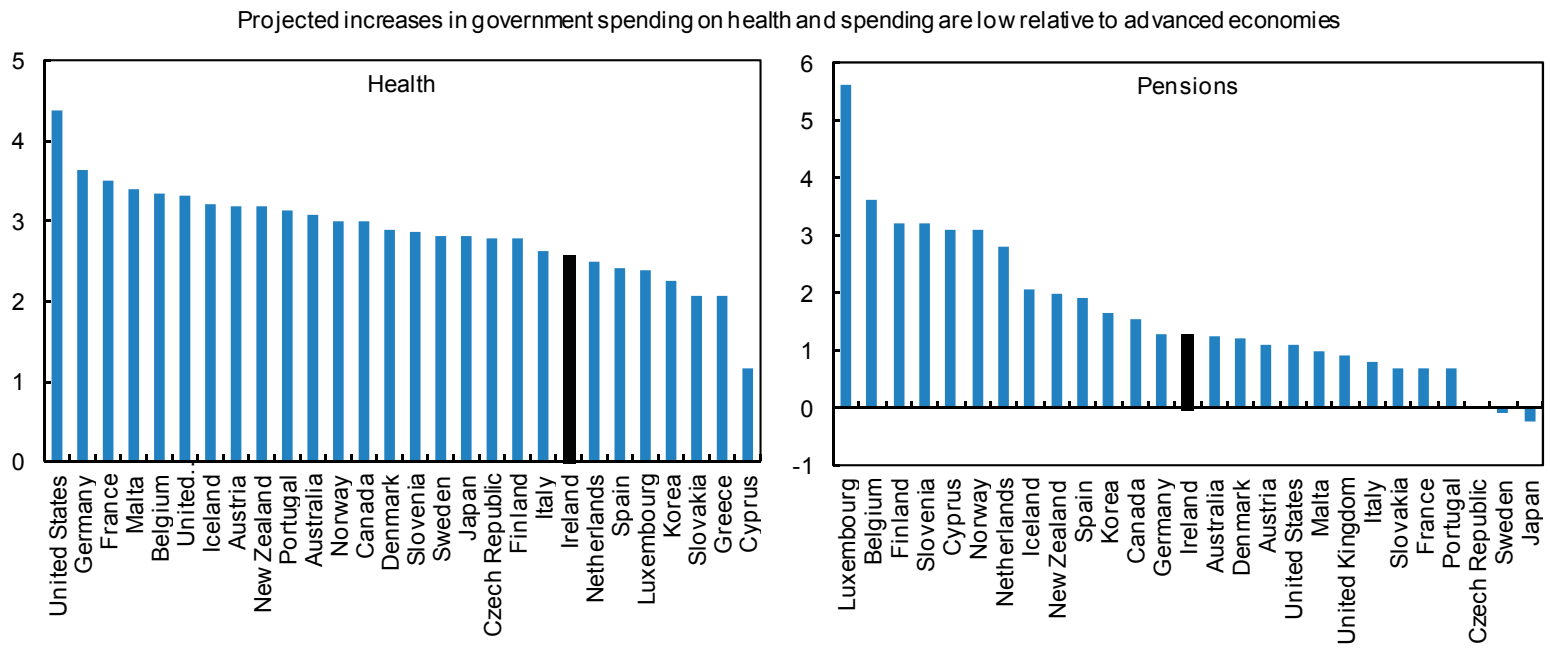

Source: IMF Fiscal Monitor Database.

\section{Structural Reforms to Raise EfFicienCy AND Growth Potential}

37. The key fiscal and financial structural reforms described above are essential to improving the prospects of economic recovery and raise the medium-term growth potential. The financial sector measures - improved banking supervision, a new bank resolution framework, and a new personal insolvency regime - will strengthen the resilience of the financial system and improve its capability to handle the challenges associated with the crisis. The fiscal reforms - medium-term budgetary framework and institutional reformsshould help to strengthen the credibility of public finances.

38. Other reforms will also help the reorientation of the economy and address the large medium-term adjustment needs. Ireland consistently ranks among the top 10 countries for ease of doing business. As such, there are no "low-hanging" fruit for reforms with quick and easy dividends. Nevertheless, the National Recovery Plan includes a strategy 
to remove remaining structural impediments to competitiveness and employment creation. Building on this Plan, the program focuses on measures relating to competition in product and services markets, labor market reform, and the management of government assets and liabilities (Box 6).

\section{Box 6. Reducing Impediments to Competitiveness and Employment Creation}

The government will introduce legislative changes to remove restrictions to trade and competition, especially in sheltered professions. The scope of competition law will be broadened to encompass all sectors; and legislative amendments proposed to enable the imposition of financial and other sanctions in civil law cases relating to competition. An independent ombudsman to promote and oversee competition in sheltered sectors will be established. In addition, for the legal profession, a package of measures will aim to reduce legal costs; and for the medical profession, restrictions on the number of qualifying general practitioners (GPs) and on the number of patients that newly qualified GPs can treat will be removed. For the pharmacy profession, it would be important to fully enforce the recent elimination of the 50 percent mark-up paid on medicines under the State's Drugs Payments Scheme.

Labor market reforms will aim to reduce the unemployment rate. The authorities are considering reforms of unemployment benefits with a view to reducing inactivity and unemployment traps, especially for unskilled workers. In particular, the reforms are likely to seek an adjustment in the replacement ratios facing the long-term unemployed; and an improvement in activation procedures to strengthen job search conditionality. These improvements would occur via better identification of jobseekers' needs, and increased counseling activities at the beginning of the unemployment spell; more effective monitoring of jobseekers' activities with regular evidence-based reports; and a mechanism for credibly sanctioning noncompliant beneficiaries. Concurrently, the authorities also intend to lower by $€ 1$ (to $€ 7.65$ ) the national minimum wage, which remains high by OECD standards, followed by a review of sector-specific minimum wage agreements, with a view to their elimination.

Other reforms aim to support the expansion of domestic businesses and aim for convergence toward cost recovery for public services. The authorities intend to improve efficiency by ensuring that investment is better targeted at key strategic road projects and maintenance which, inter alia, should have cost-reducing knock-on effects on the retail sector. A 15-day payment rule for goods and services received by public administrations will be extended beyond government departments to the wider public sector, which should help small businesses. Among public services: domestic water will be metered and charged by 2014 and the industry overseen by a water regulator; for the energy and gas sectors, the government will undertake an independent assessment (building on the forthcoming report of the Review Group on State Assets \& Liabilities), with a view to enhancing their efficiency, including through possible privatization of state-owned assets. 


\section{Program Modalities}

\section{A. Access and Conditionality}

39. The Irish authorities have requested a sizeable financing package to support their efforts to get their economy back on track. The overall size of the financing package is $€ 85$ billion (about US $\$ 113$ billion). Of this, the European Union and bilateral European lenders have pledged a total of $€ 45$ billion (about US $\$ 60$ billion). The Irish authorities have decided to contribute $€ 17.5$ billion to this effort from the nation's cash reserves and other liquid assets. The Fund's contribution would be through a three-year SDR 19.5 billion (about $€ 22.5$ billion; or US $\$ 30$ billion) arrangement, representing 2,321.8 percent of quota. The European disbursement and repayment terms would be aligned to those under the EFF.

\section{Staff proposes a three-year Extended Arrangement under the}

Extended Fund Facility. Ireland's balance of payments need is medium-term in nature and will not be resolved within the repurchase periods provided for under the credit tranche policies. It will require medium-term structural reforms to complete financial sector restructuring and unwind a private and public sector debt overhang, which would be more appropriately dealt with through the EFF. However, the program would be anchored by a strong fiscal adjustment process, and a sovereign return to market would be expected in due course. If market spreads were to decline faster than envisaged, program assumptions will be reviewed as part of the quarterly reviews. The proposed structural conditionality would focus on measures to safeguard financial stability, ensure an adequate bank restructuring process, and enhance the fiscal framework.

41. Ireland is facing a balance of payments need comprising of: (i) a financial account deficit arising, in particular, from rollovers of external government debt and outflows from Irish banks; (ii) a smaller current account deficit reflecting the legacy of lost competitiveness, which will only gradually be regained; and (iii) the need for the authorities to strengthen their reserve holdings in order to meet the government's external debt obligations as they come due and, through shoring up confidence, improve banks' ability to meet their large external debt rollover needs (by attracting deposits and market funding) and prevent substantial capital outflows.

\section{Conditionality is focused on key vulnerabilities and aimed to shore up} confidence in the short run and strengthen the policy framework in the medium term.

- Quantitative targets. The quantitative conditionality includes a performance criterion on the central government cash primary balance and an indicative target on central government net debt. In line with Fund policies, a continuous performance criterion on the non-accumulation of external payments arrears is also included. These performance criteria are described in Table 1 attached to the MEFP. 
- $\quad$ Structural benchmarks. The structural conditionality is focused on measures to strengthen the fiscal framework, safeguard financial stability, and ensure an adequate bank restructuring process and the design of a comprehensive bank resolution framework. On the fiscal front, the government will introduce a fiscal responsibility law providing for binding multi-annual expenditure ceilings by area, and establish an independent budgetary council. These measures are described in Table 2 attached to the MEFP.

\section{B. Exceptional Access Criteria}

\section{Exceptional access would be required under the program in light of the large} projected financing gap. Staff's assessment is that Ireland meets all four criteria for granting exceptional access, namely:

- Criterion 1: Exceptional balance of payments pressures in the capital account: The member is experiencing or has the potential to experience exceptional balance of payments pressures on the current or capital account resulting in a need for Fund financing that cannot be met within the normal limits. Ireland is experiencing substantial capital account pressures arising from acute liquidity pressures. Heightened market concerns have prompted rating downgrades and sharp increase in sovereign spreads which, in turn, have restricted market access to an extent that would make it impossible to cover financing needs within normal limits. The banking sector's rollover requirements on maturing external obligations and an accelerated deposit outflows could result in further pressures on the capital account. Absent the necessary backstopping of exceptional financing from the euro area and the Fund, the authorities have limited scope to stem additional flights of capital.

- Criterion 2: Sustainable debt position: A rigorous and systemic analysis indicates that there is a high probability that the member's public debt is sustainable in the medium term. However, in instances where there are significant uncertainties that make it difficult to state categorically that there is a high probability that the debt is sustainable over this period, exceptional access would be justified if there is a high risk of international systemic spillovers. Prior to March 2009, Ireland had an AAA rating on its sovereign debt. But the financial crisis exposed vulnerabilities (overstretched private sector balance sheets, outsized banking sector, high dependence on foreign financing) and led to large banks' losses, thereby increasing the need for government support for recapitalization and placing the public debt-toGDP ratio on an unsustainable path. However, the development of a comprehensive bank restructuring strategy, the potential for asset recoveries, and a resolute mediumterm adjustment program, should all help reduce the government debt back to sustainable levels in the medium term. Even though uncertainties around such a debt path make it difficult to state categorically that this is the case with a high probability, Fund support at the proposed level is justified given the high risk of international systemic spillover effects (see also paragraph 4). 
- Criterion 3: Access to private capital markets: The member has prospects of gaining or regaining access to private capital markets within the timeframe when Fund resources are outstanding. Ireland's impaired access to capital markets reflects heightened sustainability concerns linked to acute funding pressures in the banking sector. A broad restructuring strategy for the banking sector should limit the fiscal burden and restore the banking sector to health, while the exceptional financing provided by European partners and the Fund is expected to drastically reduce debt default risks and normalize access to capital markets within the maturity of EFF resources.

- Criterion 4: Strong policy reform program: The policy program of the member country provides a reasonably strong prospect of success, including not only the member's adjustment plans but also its institutional and political capacity to deliver that adjustment. The program risks are substantial, not least because of the sheer scale of the banking crisis and the large uncertainties about its resolution. At this juncture, it is extremely difficult to gauge the potential for further capital outflows. The program is designed to mitigate these risks by concentrating conditionality on the banking sector, while launching an ambitious medium-term program of economic and fiscal reforms. Ireland's sound institutions and consensus-based approach should underpin the proposed program and staff's judgment is that the program has reasonably strong prospects of success.

\section{Capacity to Repay the Fund and Risks to the Program}

44. Ireland's capacity to repay the Fund will remain satisfactory under an Extended Arrangement. Given this is Ireland's first drawing of Fund resources, Fund's cumulative exposure will remain high but manageable by the end of the program. Outstanding credit to the Fund is expected to peak in 2013-14 at about 2,320 percent of quota, and peak debt service to the Fund as a ratio of exports of goods and services will be 2.0 percent in 2017. Government debt could peak at an elevated level (125 percent of GDP) and the combined repayment for Fund/EFSM/EFSF financing will be large. However, fiscal adjustment and the resumption of growth are expected to place the debt on a declining path from 2013 onwards. Lower bank capitalization needs than projected in staff's conservative baseline scenario would also lower the peak debt ratio.

\section{That said, the risks to the program remain high:}

- Growth may be weaker than projected. The gradual recovery of the economy might not materialize as envisaged. Although the debt sustainability analysis indicates that a moderate shock could be accommodated, a prolonged period of deep recession could weaken loan repayment capacity of households and businesses and increase bank losses beyond current projections, leading the economy into a negative spiral. Analogously, wage and price deflation — coupled with contraction in activity — could have a powerful negative effect on debt dynamics. 
- The fiscal outlook might deteriorate, opening a larger financing need. The side effects of the adjustment could make fiscal consolidation more difficult than currently envisaged and lead to sharp reductions in tax revenue.

- $\quad$ Reversing the financial sector deterioration might be difficult. Low growth, deteriorating asset quality, and higher funding costs could all weigh on the banking sector. There is also a real risk of a disorderly disruption of financial pressures, which might delay the expected recovery.

- $\quad$ Political risks are considerable. Adhering to the fiscal targets and restructuring the financial sector require strong political will and public support. Despite the consensus-building approach toward the program, the likely change in government in early 2011 increases the political risks. In this context, the mission met with a range of social partners and political to outline key elements of the program and obtain their views.

- $\quad$ Access to capital markets might take longer than expected. Ireland's access to private capital market might be even more delayed than what has been assumed under the program, particularly under any of the adverse shocks shown in the debt sustainability analysis.

46. In accordance with Fund policy, staff has initiated a safeguards assessment of the Central Bank of Ireland, expected to be completed by the first review. IMF funds will be deposited in the government account at the Central Bank of Ireland (CBI). The CBI publishes its annual financial statements, which are independently audited in accordance with international standards. The most recent audit opinion for 2009 was unqualified.

\section{Staff Appraisal}

47. The program is designed to address deep-rooted structural problems and, concurrently, restore confidence in the Irish economy's future. The critically-weakened banking sector can be returned to health only at a calibrated pace. That is also the case for reversing the structural fiscal problems. While it is essential that the authorities move ahead with continued resolve, too rapid a speed could either undermine the process or create heavy short-term costs. The structural challenges for raising growth are less daunting. But growth is held back by the weakness of the banking sector and public finances. The interacting vulnerabilities create feedback loops that place the economy in a low-growth equilibrium, and hence especially susceptible to domestic and external shocks. By addressing the core structural challenges, the expectation also is that confidence will gradually return - and place the economy on a more dynamic path with better shock-absorbing capacity.

48. A leaner and more robust banking sector is the first major objective of the program. The tools to do so are clear-disposal of noncore assets, further transfer of land and property development loans to NAMA, and sale of asset portfolios (possibly through 
credit enhancements). Also, the banks that are evidently nonviable need to be wound down while transferring their deposits to safer, viable banks. Achieving this objective will require an orderly process - skillful execution will be essential to success.

49. Because this process will be drawn out - and entails short-term risks- the program provides support in the transition through additional capital to banks. The additional capital will be used to raise and maintain higher bank capital-asset ratios. These higher ratios are to be guided by those achieved by peers in other countries, but with an eye to the higher standards under Basel III. These higher standards are being increasingly seen as the norms by financial markets.

\section{The credibility of the banking system will be bolstered by stringent stress and} diagnostic tests. To account for the deterioration of the economy since the last stress tests, new tests will be complemented by a careful diagnostic of the underlying asset values. Bank capitalization based on this analysis should reassure markets that banks are adequately capitalized to deal with the further risks that they face. By thus credibly achieving the capital standards, ahead of the schedule demanded by Basel III, the expectation is that financial markets will acquire greater confidence in those Irish banks that are deemed to be viable. As such, while the program does not directly provide liquidity to banks, the confidence generated should enable over time banks to attract deposits and market funding. Meanwhile, liquidity support from the ECB will be an essential component of the program.

\section{The fiscal strategy is based on the authorities' recently published National}

Recovery Plan. The plan makes a number of pragmatic choices. These should help achieve sustainability of public finances, while paying appropriate regard to a social safety net. The Plan balances the need to press ahead with consolidation but without unduly damaging shortterm economic prospects. It emphasizes expenditure reductions to increase the likelihood that the consolidation is durable; but recognizes the need for tax increases, with a special emphasis on broadening the tax base. These overarching compositional choices are reinforced with efforts to increase expenditure efficiency and support equity considerations.

\section{While there are no "low-hanging" fruit on structural reforms for enhancing} growth, the program incorporates several measures with this objective. The authorities will pursue reduction of restrictions on trade and competition. In addition, several supportive measures are directed at increasing the level of employment. Finally, based on the report of the Review Group of State Assets and Liabilities, an assessment will be made of the scope for increased efficiency of state-owned assets. Following that assessment, the possibilities of asset privatization will be explored, especially in the electricity and gas sectors.

53. The substantial risks to the program will need to be actively managed. The key risk is that implementation will be delayed or faced with unanticipated challenges. This execution risk is particularly salient given the extreme technical delicacy of the many tasks that lie ahead. Execution is also subject to market and political developments. The principal 
risk mitigation strategy is to proceed in an adaptive and deliberate manner with appropriate consultation with the relevant constituencies.

54. In view of Ireland's balance of payments need and the comprehensive package of adjustment measures already taken and proposed by the authorities, the staff supports the authorities request for an Extended Arrangement in an amount equivalent to SDR 19.5 billion. 
Table 1. Ireland: Selected Economic Indicators, 2005-11

(Annual change unless otherwise stated)

\begin{tabular}{|c|c|c|c|c|c|c|c|}
\hline & \multirow[b]{2}{*}{2005} & \multirow[b]{2}{*}{2006} & \multirow[b]{2}{*}{2007} & \multirow[b]{2}{*}{2008} & \multirow[b]{2}{*}{2009} & \multicolumn{2}{|c|}{ Proj. } \\
\hline & & & & & & 2010 & 2011 \\
\hline \multicolumn{8}{|l|}{ National accounts (constant prices) } \\
\hline GNP & 6.0 & 6.5 & 4.5 & -3.5 & -10.7 & -3.0 & -1.5 \\
\hline GDP & 6.0 & 5.3 & 5.6 & -3.5 & -7.6 & -0.2 & 0.9 \\
\hline Domestic demand & 8.8 & 6.4 & 5.4 & -5.1 & -13.9 & -4.1 & -2.2 \\
\hline Private consumption & 6.9 & 6.7 & 6.4 & -1.5 & -7.0 & -1.4 & -1.0 \\
\hline Public consumption & 3.9 & 5.1 & 6.9 & 2.2 & -4.4 & -2.0 & -4.0 \\
\hline Gross fixed investment & 14.9 & 4.6 & 2.8 & -14.3 & -31.0 & -21.1 & -10.4 \\
\hline Net exports $1 /$ & -2.0 & -0.8 & 0.8 & 1.5 & 3.8 & 3.5 & 3.7 \\
\hline Exports of goods and services & 4.8 & 4.8 & 8.2 & -0.8 & -4.1 & 5.8 & 4.5 \\
\hline Imports of goods and services & 8.3 & 6.4 & 7.8 & -2.9 & -9.7 & 2.2 & 0.7 \\
\hline Gross national saving (in percent of GDP) & 23.6 & 24.8 & 21.7 & 16.4 & 11.5 & 10.0 & 10.9 \\
\hline Private & 18.8 & 18.4 & 18.7 & 20.6 & 25.2 & 24.7 & 23.9 \\
\hline Public & 4.8 & 5.9 & 3.0 & -4.2 & -13.8 & -14.8 & -13.0 \\
\hline Gross investment (in percent of GDP) & 27.2 & 28.0 & 27.3 & 22.3 & 14.1 & 11.8 & 11.1 \\
\hline Private & 23.7 & 24.2 & 22.5 & 16.8 & 9.4 & 7.0 & 7.5 \\
\hline Public & 3.5 & 3.8 & 4.8 & 5.5 & 4.7 & 4.7 & 3.6 \\
\hline \multicolumn{8}{|l|}{ Prices, wages and employment } \\
\hline Harmonized Index of Consumer Prices (annual average) & 2.2 & 2.7 & 2.9 & 3.1 & -1.7 & -1.6 & -0.5 \\
\hline Average wages, all economy & 5.1 & 5.5 & 5.2 & 3.5 & -1.0 & -3.7 & -1.1 \\
\hline Output, manufacturing & 4.1 & 3.1 & 5.3 & -2.1 & -7.2 & -0.2 & 0.9 \\
\hline GNP/employment & 1.0 & 2.1 & 0.8 & -2.4 & -2.7 & 1.5 & -1.0 \\
\hline Employment & 4.9 & 4.4 & 3.6 & -1.1 & -8.1 & -4.5 & -0.5 \\
\hline Unemployment rate (in percent) & 4.4 & 4.4 & 4.6 & 6.3 & 11.8 & 13.5 & 13.5 \\
\hline \multicolumn{8}{|l|}{ Money and credit (end-period) } \\
\hline Irish contribution to euro area money supply: M3 & 22.1 & 28.5 & 9.6 & -1.9 & -1.5 & $\ldots$ & $\ldots$ \\
\hline Irish resident private sector credit $2 /$ & 28.8 & 25.9 & 17.0 & 7.3 & -7.6 & $\ldots$ & $\ldots$ \\
\hline \multicolumn{8}{|l|}{ Financial and asset markets (end-period) } \\
\hline Three-month interbank rate & 2.5 & 3.7 & 4.6 & 3.0 & 0.6 & $\ldots$ & $\ldots$ \\
\hline 10-year government bond & 3.3 & 4.0 & 4.5 & 4.4 & 4.9 & $\ldots$ & $\ldots$ \\
\hline ISEQ index & 16.8 & 27.8 & -26.3 & -66.2 & 27.0 & $\ldots$ & $\ldots$ \\
\hline House prices (permanent tsb index/ESRI) & 9.3 & 11.8 & -7.3 & -9.1 & -18.5 & $\ldots$ & ... \\
\hline \multicolumn{8}{|l|}{ Public finance (in percent of GDP) } \\
\hline General government balance & 1.6 & 2.9 & 0.1 & -7.3 & -14.4 & -32.0 & -10.5 \\
\hline Primary balance & 2.7 & 3.8 & 0.9 & -6.3 & -12.3 & -29.0 & -6.9 \\
\hline General government debt & 27.2 & 24.8 & 25.0 & 44.4 & 65.6 & 98.9 & 112.8 \\
\hline \multicolumn{8}{|l|}{ External trade and balance of payments } \\
\hline Balance of goods and services (percent of GDP) & 11.7 & 10.3 & 9.9 & 9.0 & 15.0 & 19.0 & 22.4 \\
\hline Current account (percent of GDP) & -3.5 & -3.6 & -5.3 & -5.6 & -3.0 & -2.4 & -1.2 \\
\hline \multicolumn{8}{|l|}{ Effective exchange rates (1999:Q1=100, annual average) } \\
\hline Nominal & 104.1 & 104.4 & 107.4 & 113.0 & 112.5 & $\ldots$ & $\ldots$ \\
\hline Real (CPI based) & 115.4 & 116.0 & 120.1 & 125.6 & 121.9 & $\cdots$ & ... \\
\hline \multicolumn{8}{|l|}{ Memorandum items: } \\
\hline Population (in millions) & 4.1 & 4.2 & 4.3 & 4.4 & 4.5 & 4.5 & 4.5 \\
\hline GDP per capita (in euros) & 39,265 & 41,828 & 43,645 & 40,702 & 35,801 & 35,014 & 35,589 \\
\hline
\end{tabular}

Sources: Department of Finance; Central Bank of Ireland; IFS; Bloomberg; and Fund staff calculations.

1/ Contribution to growth. However, the data for exports and imports of goods and services are annual growth rates. 2/ Adjusted change, which includes the effects of transactions between credit institutions and non-bank international financial companies and valuation effects arising from exchange rate movements. 
Table 2. Ireland: Medium-Term Scenario, 2007-15 (Percentage change, unless otherwise indicated)

\begin{tabular}{|c|c|c|c|c|c|c|c|c|c|}
\hline & 2007 & 2008 & 2009 & 2010 & 2011 & 2012 & 2013 & 2014 & 2015 \\
\hline Real GNP & 4.5 & -3.5 & -10.7 & -3.0 & -1.5 & 0.8 & 1.4 & 2.3 & 3.4 \\
\hline Real GDP & 5.6 & -3.5 & -7.6 & -0.2 & 0.9 & 1.9 & 2.4 & 3.0 & 3.4 \\
\hline Real domestic demand & 5.4 & -5.1 & -13.9 & -4.1 & -2.2 & 0.5 & 1.2 & 1.9 & 2.9 \\
\hline Real final domestic demand & 5.5 & -4.3 & -12.4 & -5.3 & -3.1 & 0.5 & 1.3 & 2.0 & 2.9 \\
\hline Private consumption & 6.4 & -1.5 & -7.0 & -1.4 & -1.0 & 0.5 & 1.2 & 1.5 & 2.2 \\
\hline Public consumption & 6.9 & 2.2 & -4.4 & -2.0 & -4.0 & -1.8 & -1.5 & -1.5 & 0.0 \\
\hline Fixed investment & 2.8 & -14.3 & -31.0 & -21.1 & -10.4 & 3.5 & 5.0 & 8.0 & 9.0 \\
\hline Change in stocks $1 /$ & 0.0 & -0.8 & -1.4 & 1.1 & 0.8 & 0.0 & 0.0 & 0.0 & 0.0 \\
\hline Net exports $1 /$ & 0.8 & 1.5 & 3.8 & 3.5 & 3.7 & 1.5 & 1.5 & 1.5 & 1.2 \\
\hline Exports & 8.2 & -0.8 & -4.1 & 5.8 & 4.5 & 4.5 & 4.6 & 4.7 & 4.7 \\
\hline Imports & 7.8 & -2.9 & -9.7 & 2.2 & 0.7 & 3.7 & 4.0 & 4.1 & 4.6 \\
\hline Current account $2 /$ & -5.3 & -5.6 & -3.0 & -2.4 & -1.2 & -0.2 & -0.4 & -0.5 & -0.5 \\
\hline Gross national saving $2 /$ & 21.7 & 16.4 & 11.5 & 10.0 & 10.9 & 11.3 & 11.3 & 11.7 & 12.3 \\
\hline Private & 18.7 & 20.6 & 25.2 & 24.7 & 23.9 & 21.8 & 20.6 & 17.4 & 17.5 \\
\hline Public & 3.0 & -4.2 & -13.8 & -14.8 & -13.0 & -10.5 & -9.3 & -5.6 & -5.2 \\
\hline Gross investment 2/ & 27.3 & 22.3 & 14.1 & 11.8 & 11.1 & 11.2 & 11.5 & 12.0 & 12.6 \\
\hline Private & 22.5 & 16.8 & 9.4 & 7.0 & 7.5 & 7.9 & 8.4 & 9.0 & 9.6 \\
\hline Public & 4.8 & 5.5 & 4.7 & 4.7 & 3.6 & 3.3 & 3.1 & 3.0 & 3.0 \\
\hline \multicolumn{10}{|l|}{ Prices } \\
\hline Consumer prices & 2.9 & 3.1 & -1.7 & -1.6 & -0.5 & 0.2 & 1.3 & 1.3 & 1.7 \\
\hline Wages & 5.2 & 3.5 & -1.0 & -3.7 & -1.1 & 0.4 & 1.1 & 1.7 & 1.8 \\
\hline \multicolumn{10}{|l|}{ Labor market } \\
\hline Employment & 3.6 & -1.1 & -8.1 & -4.5 & -0.5 & 0.8 & 1.2 & 1.5 & 1.9 \\
\hline Average unemployment rate & 4.6 & 6.3 & 11.8 & 13.5 & 13.5 & 12.8 & 12.3 & 11.5 & 10.7 \\
\hline \multicolumn{10}{|l|}{ Public finance } \\
\hline General government balance 2/ & 0.1 & -7.3 & -14.4 & -32.0 & -10.5 & -8.6 & -7.5 & -5.1 & -4.8 \\
\hline General government structural balance 3/ & -7.3 & -11.3 & -9.6 & -8.8 & -6.1 & -4.8 & -4.3 & -3.5 & -3.5 \\
\hline General government gross debt 2/ & 25.0 & 44.4 & 65.6 & 98.9 & 112.8 & 120.0 & 124.5 & 124.1 & 123.0 \\
\hline Output gap $3 /$ & 6.5 & 2.2 & -6.0 & -6.3 & -5.9 & -4.9 & -3.8 & -2.1 & -0.8 \\
\hline
\end{tabular}

Sources: CSO; Department of Finance; and IMF staff calculations.

$1 /$ Contributions to growth.

2/ In percent of GDP.

$3 /$ In percent of potential output. 
Table 3. Ireland: General Government Finances 2006-15 1/ (In percent of GDP)

\begin{tabular}{|c|c|c|c|c|c|c|c|c|c|c|}
\hline & \multicolumn{3}{|c|}{ Actual } & \multirow[b]{2}{*}{2009} & \multicolumn{5}{|c|}{ Staff Projections } & \multirow[b]{2}{*}{2015} \\
\hline & 2006 & 2007 & 2008 & & 2010 & 2011 & 2012 & 2013 & 2014 & \\
\hline Current balance & 6.5 & 4.7 & -1.2 & -7.6 & -8.3 & -7.3 & -5.8 & -5.1 & -2.8 & -2.5 \\
\hline Current revenue, of which: & 35.2 & 34.6 & 33.3 & 33.1 & 33.4 & 34.0 & 34.5 & 34.9 & 35.4 & 35.6 \\
\hline Tax revenue (including taxes on capital) & 27.1 & 26.3 & 23.9 & 22.0 & 21.3 & 22.1 & 22.8 & 23.4 & 23.9 & 24.2 \\
\hline Income tax & 7.0 & 7.2 & 7.3 & 7.4 & 7.2 & 8.4 & 8.8 & 9.3 & 9.5 & 9.7 \\
\hline Corporate tax & 3.8 & 3.4 & 2.8 & 2.4 & 2.5 & 2.5 & 2.6 & 2.6 & 2.6 & 2.6 \\
\hline VAT & 7.6 & 7.5 & 7.5 & 6.7 & 6.3 & 6.0 & 6.0 & 6.2 & 6.2 & 6.3 \\
\hline Excise duty & 3.2 & 3.2 & 3.0 & 2.9 & 2.8 & 2.6 & 2.7 & 2.7 & 2.7 & 2.7 \\
\hline Capital taxes & 1.9 & 1.8 & 1.0 & 0.5 & 0.5 & 0.4 & 0.5 & 0.5 & 0.5 & 0.5 \\
\hline Stamp duty & 2.0 & 1.7 & 0.9 & 0.6 & 0.5 & 0.5 & 0.5 & 0.5 & 0.6 & 0.6 \\
\hline Other taxes & 1.5 & 1.5 & 1.4 & 1.4 & 1.4 & 1.5 & 1.6 & 1.7 & 1.8 & 1.8 \\
\hline Social security receipts & 4.6 & 4.8 & 5.2 & 5.6 & 5.8 & 5.8 & 5.9 & 5.9 & 5.9 & 5.9 \\
\hline Miscellaneous & 3.5 & 3.6 & 4.2 & 5.6 & 6.3 & 6.1 & 5.9 & 5.5 & 5.5 & 5.5 \\
\hline Current expenditure, of which: & 28.7 & 29.9 & 34.4 & 40.8 & 41.7 & 41.3 & 40.3 & 40.0 & 38.2 & 38.1 \\
\hline Interest payments & 0.9 & 0.8 & 1.0 & 2.2 & 3.0 & 3.8 & 4.4 & 6.1 & 6.3 & 6.3 \\
\hline Goods and services & 5.3 & 5.6 & 5.9 & 6.2 & 5.9 & 5.6 & 5.0 & 4.5 & 3.9 & 3.9 \\
\hline Compensation of employees & 9.3 & 9.5 & 11.2 & 12.4 & 11.7 & 10.8 & 10.1 & 9.5 & 9.0 & 9.0 \\
\hline Current transfers & 12.3 & 13.1 & 15.3 & 18.7 & 19.4 & 19.3 & 18.8 & 17.8 & 16.7 & 16.6 \\
\hline Depreciation & 0.9 & 0.9 & 1.1 & 1.4 & 1.6 & 1.8 & 1.9 & 2.1 & 2.2 & 2.2 \\
\hline Primary current expenditure & 27.8 & 29.1 & 33.4 & 38.6 & 38.7 & 37.5 & 35.9 & 33.9 & 31.9 & 31.8 \\
\hline Capital balance & -3.6 & -4.7 & -6.2 & -6.8 & -23.8 & -3.2 & -2.8 & -2.5 & -2.3 & -2.3 \\
\hline Capital receipts (excluding taxes on capital) & 1.1 & 1.2 & 1.0 & 1.1 & 1.2 & 1.4 & 1.5 & 1.4 & 1.4 & 1.4 \\
\hline Gross capital formation & 3.8 & 4.8 & 5.5 & 4.7 & 4.7 & 3.6 & 3.3 & 3.1 & 3.0 & 3.0 \\
\hline Capital transfers & 0.9 & 1.1 & 1.8 & 3.2 & 20.3 & 1.0 & 1.0 & 0.8 & 0.7 & 0.8 \\
\hline General government balance & 2.9 & 0.1 & -7.3 & -14.4 & -32.0 & -10.5 & -8.6 & -7.5 & -5.1 & -4.8 \\
\hline Primary balance & 3.8 & 0.9 & -6.3 & -12.3 & -29.0 & -6.7 & -4.1 & -1.4 & 1.2 & 1.5 \\
\hline Primary balance excl. bank support measures & 3.8 & 0.9 & -6.3 & -9.7 & -9.6 & -6.7 & -4.1 & -1.4 & 1.2 & 1.5 \\
\hline \multicolumn{11}{|l|}{ Memorandum items: } \\
\hline Structural government balance & -4.0 & -7.2 & -11.2 & -9.6 & -8.8 & -6.1 & -4.8 & -4.3 & -3.5 & -3.5 \\
\hline General government gross debt (as percent of GDP) & 24.8 & 25.0 & 44.4 & 65.6 & 98.9 & 112.8 & 120.0 & 124.5 & 124.1 & 123.0 \\
\hline Central government net debt (as percent of GDP) 2/ & 10.1 & 9.5 & 19.8 & 39.0 & 49.9 & .. & .. & .. & .. & .. \\
\hline Exchequer primary balance (as percent of GDP) & 2.3 & 0.0 & -6.2 & -13.8 & -9.6 & .. & .. & .. & .. & .. \\
\hline Output gap & 2.8 & 6.5 & 2.2 & -6.0 & -6.3 & -5.9 & -4.9 & -3.8 & -2.1 & -0.8 \\
\hline Growth in nominal GDP & 9.3 & 6.8 & -5.0 & -11.3 & -1.9 & 1.3 & 2.7 & 3.8 & 4.6 & 5.0 \\
\hline
\end{tabular}

Sources: Department of Finance; and staff estimates.

1/ The general government numbers incorporate the full amount of prospective IMF/EU financing.

2/ Central government net debt is defined as National Debt -- the conventional measure of net debt -- less liquid assets of the NPRF.

These are defined as the sum of cash, listed equities and bonds. The figure for 2010 is the end-November provisional figure. 
Table 4. Ireland: Indicators of External and Financial Vulnerability, 2003-10

\begin{tabular}{|c|c|c|c|c|c|c|c|c|}
\hline & 2003 & 2004 & 2005 & 2006 & 2007 & 2008 & 2009 & 2010 \\
\hline \multicolumn{9}{|l|}{ External indicators } \\
\hline Exports (annual percent change, value in euros) & -4.5 & 6.9 & 5.9 & 6.2 & 8.3 & -1.4 & -3.6 & 6.4 \\
\hline Imports (annual percent change, value in euros) & -5.5 & 8.6 & 10.3 & 8.9 & 9.5 & -1.1 & -10.1 & 2.7 \\
\hline Terms of trade (goods, annual percent change) & -0.5 & -1.4 & 1.2 & -4.6 & -3.3 & -4.7 & 3.3 & \\
\hline Current account balance (in percent of GDP) & 0.0 & -0.6 & -3.5 & -3.6 & -5.3 & -5.6 & -3.0 & -2.4 \\
\hline Capital and financial account balance (in percent of GDP) & -0.9 & 2.7 & -0.1 & 2.8 & 6.4 & 9.0 & -2.9 & -8.8 \\
\hline \multicolumn{9}{|l|}{ Of which: } \\
\hline Inward portfolio investment & 74.8 & 100.0 & 106.9 & 124.9 & 86.4 & -10.2 & 5.7 & 19.7 \\
\hline Inward foreign direct investment & 14.4 & -5.7 & -15.7 & -2.5 & 9.5 & -6.2 & 11.1 & 2.5 \\
\hline Other investment liabilities & 57.1 & 39.7 & 57.7 & 74.5 & 92.1 & 85.4 & -55.2 & 18.5 \\
\hline U.S. dollar per euro (period average) & 1.13 & 1.24 & 1.25 & 1.26 & 1.37 & 1.47 & 1.39 & 1.31 \\
\hline U.K. pound per euro (period average) & 0.69 & 0.68 & 0.68 & 0.68 & 0.68 & 0.79 & 0.89 & 0.85 \\
\hline \multicolumn{9}{|l|}{ Financial markets indicators } \\
\hline General government debt (in percent of GDP) & 30.9 & 29.4 & 27.2 & 24.8 & 25.0 & 44.4 & 65.6 & 98.9 \\
\hline Government bond yield (in percent, 10 -year, end-period) $1 /$ & 4.3 & 3.5 & 3.3 & 4.0 & 4.5 & 4.4 & 4.9 & 6.6 \\
\hline Spread of government bond yield with Germany (in percent, end of period) $1 /$ & -0.3 & 0.4 & 0.1 & -0.3 & 0.0 & 1.3 & 1.3 & 4.3 \\
\hline Real government bond yield (in percent, 10-year, period average, based on HICP) 1/ & 0.1 & 1.9 & 1.2 & 1.0 & 1.6 & 1.5 & 6.6 & 8.2 \\
\hline Annual change in ISEQ index (in percent, end of period) $1 /$ & 12.2 & 26.8 & 16.8 & 27.8 & -26.3 & -66.2 & 27.0 & 17.6 \\
\hline Personal lending interest rate (in percent) $2 /$ & 9.9 & 9.9 & 10.1 & 11.2 & 11.7 & 11.9 & 11.1 & 11.3 \\
\hline Standard variable mortgage interest rate (in percent) $2 /$ & 3.5 & 3.5 & 3.6 & 4.8 & 5.4 & 4.8 & 3.3 & 3.4 \\
\hline \multicolumn{9}{|l|}{ Financial sector risk indicators } \\
\hline Annual credit growth rates (to Irish resident private sector, in percent) $3 /$ & 17.9 & 26.6 & 28.8 & 25.9 & 17.0 & 7.3 & -7.6 & 1.7 \\
\hline & \multicolumn{7}{|c|}{ Of which: } & 36.7 \\
\hline House mortgage finance $1 /$ & 34.2 & 36.7 & 36.5 & 34.9 & 32.8 & 29.0 & 30.1 & 32.2 \\
\hline Other housing finance $1 /$ & 0.3 & 0.3 & 0.2 & 0.4 & 0.3 & 0.3 & 0.2 & 0.2 \\
\hline Other personal lending $1 /$ & 8.3 & 8.7 & 7.9 & 7.0 & 6.5 & 5.9 & 5.3 & 4.4 \\
\hline Irish resident household mortgage debt annual growth rates (in percent) 4 / & 25.5 & 26.5 & 27.1 & 24.2 & 13.4 & 5.9 & -0.3 & -2.0 \\
\hline \multicolumn{9}{|l|}{ Commercial property lending as a percent of total loans } \\
\hline Foreign-currency denominated assets (in percent of total assets) $1 /$ & 32.5 & 29.4 & 33.9 & 33.7 & 36.5 & 31.7 & 34.3 & 34.0 \\
\hline Foreign-currency denominated liabilities (in percent of total liabilities) $1 /$ & 34.2 & 32.2 & 35.9 & 36.9 & 41.1 & 35.5 & 31.1 & 28.4 \\
\hline Contingent and off-balance sheet accounts (in percent of total assets) $1 / 6$ / & 538 & 662 & 879 & 1133 & $\ldots$ & $\ldots$ & $\ldots$ & $\ldots$ \\
\hline Non-performing loans (in percent of total loans) $1 / 7$ I & 0.9 & 0.8 & 0.7 & 0.7 & 0.8 & 2.6 & 9.0 & 12.9 \\
\hline Total provisions for loan losses (in percent of total loans) $1 /$ & 0.9 & 0.7 & 0.5 & 0.4 & 0.4 & 1.3 & 4.0 & 5.7 \\
\hline Regulatory capital to risk-weighted assets of domestic banks (in percent) $1 /$ & 13.9 & 12.6 & 12.0 & 10.9 & 10.7 & 10.6 & 10.9 & 11.1 \\
\hline Bank return on assets (before tax, in percent) & 0.9 & 1.1 & 0.8 & 0.8 & 0.7 & $\ldots$ & $\ldots$ & $\cdots$ \\
\hline Bank return on equity (before tax, in percent) & 17.8 & 20.7 & 19.6 & 19.1 & 16.4 & $\ldots$ & $\ldots$ & $\ldots$ \\
\hline Liquid assets of all banks to total assets (liquid asset ratio, in percent) & 33.6 & 33.0 & 34.2 & 32.7 & 28.4 & $\ldots$ & $\ldots$ & $\ldots$ \\
\hline Liquid assets of all banks to short-term liabilities (in percent) & 41.2 & 40.0 & 40.2 & 38.4 & 34.4 & $\ldots$ & $\ldots$ & \\
\hline Deposits to $\mathrm{M} 3$ ratio $1 / 8$ / & 1.5 & 1.4 & 1.4 & 1.3 & 1.4 & 1.3 & 1.4 & 1.4 \\
\hline Loan-to-deposit ratio vis-à-vis Irish residents 1/ 9 / & 1.5 & 1.6 & 1.8 & 1.9 & 2.1 & 2.2 & 2.1 & 2.1 \\
\hline vis-à-vis total $1 / 9 /$ & 1.6 & 1.7 & 1.8 & 1.9 & 2.1 & 2.2 & 2.2 & 2.2 \\
\hline \multicolumn{9}{|l|}{ Concentration ratios in the banking sector } \\
\hline No. of banks accounting for 25 percent of total assets & 2.0 & 2.0 & 2.0 & 3.0 & 3.0 & 2.0 & 2.0 & 2.0 \\
\hline No. of banks accounting for 75 percent of total assets & 18.0 & 17.0 & 16.0 & 17.0 & 15.0 & 14.0 & 13.0 & 12.0 \\
\hline Share of state-owned banks in total assets (in percent) & 0.0 & 0.0 & 0.0 & 0.0 & 0.0 & 0.0 & 6.0 & 7.0 \\
\hline Share of foreign-owned banks in total assets (in percent) & 31.0 & 34.0 & 32.3 & 36.3 & 32.2 & 62.0 & 65.0 & 62.0 \\
\hline
\end{tabular}

Sources: Data provided by the authorities; Central Bank of Ireland; International Financial Statistics; Bloomberg; and Fund staff estimates.

1/ Data for 2010 refers to end-September 2010.

2/ Data for 2010 refers to end-June 2010.

3/ Data for 2010 refers to end-March 2010.

4 / Including securitisations.

$5 /$ Includes lending for construction and real estate activities.

6/ Credit equivalent values.

7/ Owing to differences in classification, international comparisons of nonperforming loans are indicative only.

8/ Non-government deposits vis-à-vis Irish and nonresidents. The M3 compiliation methodology has been amended in line with Eurosystem requirements.

9/ Nongovernment credit/nongovernment deposits ratio. 
Table 5. Ireland: Summary of Balance of Payments, 2008-15 (In billions of euros)

\begin{tabular}{|c|c|c|c|c|c|c|c|c|}
\hline & 2008 & 2009 & 2010 & 2011 & 2012 & 2013 & 2014 & 2015 \\
\hline & & & \multicolumn{6}{|c|}{ Projections } \\
\hline Current account balance & -10.2 & -4.9 & -3.8 & -1.9 & -0.2 & -0.7 & -0.8 & -0.9 \\
\hline Balance of goods and services & 16.1 & 24.0 & 29.8 & 35.6 & 38.8 & 41.8 & 45.2 & 48.1 \\
\hline Goods balance & 23.8 & 32.4 & 35.8 & 34.5 & 36.7 & 38.8 & 40.3 & 41.5 \\
\hline Exports & 81.0 & 77.0 & 82.7 & 81.2 & 85.5 & 89.7 & 94.0 & 98.6 \\
\hline Imports & -57.2 & -44.7 & -46.9 & -46.6 & -48.8 & -50.8 & -53.7 & -57.0 \\
\hline Services balance & 7.7 & 8.4 & 5.9 & -1.0 & -2.1 & -2.9 & -4.9 & -6.6 \\
\hline Credit & 67.9 & 66.6 & 69.9 & 80.3 & 85.6 & 91.5 & 98.1 & 105.1 \\
\hline Debit & -75.6 & -75.0 & -75.8 & -79.2 & -83.4 & -88.6 & -93.1 & -98.5 \\
\hline Income balance & -25.2 & -27.9 & -31.8 & -36.2 & -37.7 & -41.0 & -44.6 & -47.5 \\
\hline Credit & 84.0 & 54.5 & 63.3 & 75.2 & 68.7 & 63.9 & 59.8 & 56.6 \\
\hline Debit & 109.2 & 82.4 & 95.1 & 111.4 & 106.4 & 105.0 & 104.3 & 104.1 \\
\hline Current transfers (net) & -1.2 & -0.9 & -1.8 & -1.2 & -1.3 & -1.4 & -1.5 & -1.6 \\
\hline Capital and financial account balance & 16.2 & -4.6 & -2.2 & -35.2 & -19.4 & -4.3 & 0.8 & 0.9 \\
\hline Capital account balance & 0.0 & -1.3 & 0.0 & -0.1 & 0.0 & 0.0 & 0.0 & 0.0 \\
\hline Financial account & 16.1 & -3.3 & -2.2 & -35.2 & -19.4 & -4.2 & 0.9 & 1.0 \\
\hline Direct investment & -24.2 & 0.5 & -2.8 & -3.4 & -3.3 & -1.6 & 0.2 & 0.1 \\
\hline Portfolio investment & -45.7 & 18.8 & -1.6 & -9.3 & -3.8 & -1.1 & 0.1 & 0.0 \\
\hline Other investment & 86.1 & -22.6 & 2.8 & -13.8 & -2.8 & -1.3 & 0.1 & 0.0 \\
\hline Reserve assets (increase $=-$ ) $1 /$ & -0.1 & 0.1 & -0.6 & -8.6 & -9.5 & -0.2 & 0.5 & 0.8 \\
\hline Net errors and omissions & -6.0 & 9.4 & 0.3 & 0.0 & 0.0 & 0.0 & 0.0 & 0.0 \\
\hline \multirow[t]{2}{*}{ Financing gap } & 0.0 & 0.0 & 5.8 & 37.1 & 19.7 & 5.0 & 0.0 & 0.0 \\
\hline & \multicolumn{8}{|c|}{ (In percent of GDP) } \\
\hline Current account balance & -5.7 & -3.0 & -2.4 & -1.2 & -0.2 & -0.4 & -0.5 & -0.5 \\
\hline Balance on goods and services & 9.0 & 15.0 & 19.0 & 22.4 & 23.8 & 24.7 & 25.5 & 25.9 \\
\hline Goods balance & 13.2 & 20.3 & 22.8 & 21.8 & 22.5 & 22.9 & 22.8 & 22.3 \\
\hline Services balance & 4.3 & 5.3 & 3.8 & -0.6 & -1.3 & -1.7 & -2.8 & -3.5 \\
\hline Income balance & -14.0 & -17.5 & -20.3 & -22.8 & -23.1 & -24.2 & -25.2 & -25.5 \\
\hline Current transfers & -0.6 & -0.6 & -1.2 & -0.8 & -0.8 & -0.8 & -0.9 & -0.9 \\
\hline Capital and financial account balance & 9.0 & -2.9 & -1.4 & -22.2 & -11.9 & -2.5 & 0.5 & 0.5 \\
\hline Capital account balance & 0.0 & -0.8 & 0.0 & 0.0 & 0.0 & 0.0 & 0.0 & 0.0 \\
\hline Financial account & 9.0 & -2.1 & -1.4 & -22.2 & -11.9 & -2.5 & 0.5 & 0.5 \\
\hline Direct investment & -13.4 & 0.3 & -1.8 & -2.1 & -2.0 & -1.0 & 0.1 & 0.1 \\
\hline Portfolio investment & -25.4 & 11.8 & -1.0 & -5.9 & -2.3 & -0.7 & 0.0 & 0.0 \\
\hline Other investment & 47.9 & -14.2 & 1.8 & -8.7 & -1.7 & -0.8 & 0.0 & 0.0 \\
\hline Reserve assets (increase $=-$ ) $1 /$ & 0.0 & 0.0 & -0.4 & -5.4 & -5.8 & -0.1 & 0.3 & 0.4 \\
\hline Net errors and omissions & -3.3 & 5.9 & 0.2 & 0.0 & 0.0 & 0.0 & 0.0 & 0.0 \\
\hline Financing gap & 0.0 & 0.0 & 3.7 & 23.4 & 12.1 & 2.9 & 0.0 & 0.0 \\
\hline \multicolumn{9}{|l|}{ Memorandum items: } \\
\hline \multicolumn{9}{|c|}{ Potential sources to fill the gap (billions of euro) } \\
\hline EU/Bilateral loans & $\ldots$ & $\ldots$ & 0.0 & 28.6 & 13.1 & 3.3 & $\ldots$ & $\ldots$ \\
\hline IMF & $\cdots$ & $\cdots$ & 5.8 & 8.5 & 6.6 & 1.7 & $\ldots$ & $\ldots$ \\
\hline External debt (percent of GDP) & 940.4 & 1036.9 & 1084.9 & 1096.5 & 1086.6 & 1059.1 & 1016.3 & 971.7 \\
\hline Public sector & 56.8 & 80.6 & 125.5 & 139.1 & 149.1 & 154.0 & 152.7 & 150.9 \\
\hline Private sector & 883.6 & 956.3 & 959.5 & 957.4 & 937.4 & 905.0 & 863.7 & 820.8 \\
\hline
\end{tabular}

Sources: National authorities, and staff estimates and projections.

1 / The increase in reserves includes unused amounts of program disbursements in the government's account at the central bank, including in euros. 
Table 6. Ireland: External Financing Requirements and Sources, 2008-15 (In billions of euros)

\begin{tabular}{|c|c|c|c|c|c|c|c|c|}
\hline & 2008 & 2009 & 2010 & 2011 & 2012 & 2013 & 2014 & 2015 \\
\hline & & & \multicolumn{6}{|c|}{ Projections } \\
\hline Gross Financing Requirements & 682.0 & 805.5 & 731.4 & 743.9 & 753.5 & 761.5 & 764.7 & 745.5 \\
\hline Current account deficit & 10.2 & 4.9 & 3.8 & 1.8 & 0.3 & 0.7 & 0.8 & 0.9 \\
\hline Medium- and long-term debt amortization 1/ & 56.6 & 60.2 & 79.0 & 71.0 & 66.0 & 59.8 & 56.3 & 37.9 \\
\hline Public sector 2/ & 11.3 & 23.9 & 17.7 & 25.9 & 24.3 & 23.5 & 20.3 & 11.5 \\
\hline Banks & 40.9 & 30.1 & 55.2 & 34.8 & 35.6 & 28.5 & 27.1 & 23.4 \\
\hline Corporates & 4.4 & 6.2 & 6.1 & 10.3 & 6.1 & 7.8 & 8.9 & 3.0 \\
\hline Short-term debt amortization & 615.2 & 740.4 & 648.5 & 671.0 & 687.2 & 701.0 & 707.5 & 706.6 \\
\hline Public sector \& Central Bank of Ireland & 1.4 & 63.4 & 69.0 & 109.4 & 104.7 & 106.0 & 108.9 & 111.0 \\
\hline Central Bank of Ireland 3/ & 0.6 & 44.4 & 53.5 & 102.0 & 102.0 & 102.0 & 102.0 & 102.0 \\
\hline Public sector 4/ & 0.8 & 19.0 & 15.5 & 7.4 & 2.7 & 4.0 & 6.9 & 9.0 \\
\hline Banks & 500.0 & 566.3 & 493.2 & 468.5 & 494.1 & 506.6 & 510.2 & 498.4 \\
\hline Corporates & 113.7 & 110.7 & 86.4 & 93.1 & 88.4 & 88.4 & 88.4 & 97.3 \\
\hline Sources of Financing & 682.0 & 805.5 & 725.6 & 706.8 & 733.8 & 756.6 & 764.7 & 745.5 \\
\hline Capital account (net) & 0.0 & -1.3 & 0.0 & -0.1 & 0.0 & 0.0 & 0.0 & 0.0 \\
\hline Foreign direct investment (net) & -24.2 & 0.5 & -2.8 & -3.4 & -3.3 & -1.6 & 0.2 & 0.1 \\
\hline Outward & -12.9 & -17.2 & -6.7 & -3.3 & -3.3 & -1.7 & 0.2 & 0.1 \\
\hline Inward & -11.2 & 17.7 & 3.9 & 0.0 & 0.0 & 0.0 & 0.0 & 0.0 \\
\hline Equities (net) & 15.1 & 8.7 & 11.7 & 5.0 & -6.6 & 3.3 & -0.2 & -0.1 \\
\hline by nonresidents & -7.6 & 19.0 & 12.8 & 7.2 & -3.2 & 0.8 & 0.0 & 0.0 \\
\hline Assets drawdown (- increase) & -117.9 & 85.6 & -26.7 & -25.7 & -1.3 & -7.0 & 0.9 & 0.9 \\
\hline New borrowing and debt rollover & 808.9 & 711.9 & 749.1 & 730.9 & 745.0 & 761.9 & 763.8 & 744.5 \\
\hline Medium and long-term borrowing & 67.6 & 63.4 & 72.6 & 40.6 & 41.1 & 54.4 & 57.2 & 38.2 \\
\hline Public sector & 20.7 & 44.9 & 17.4 & 0.0 & 3.0 & 18.0 & 20.3 & 11.5 \\
\hline Banks & -35.3 & -3.4 & 49.7 & 31.3 & 32.0 & 28.5 & 27.1 & 23.4 \\
\hline Corporates & 82.2 & 22.0 & 5.5 & 9.3 & 6.1 & 7.8 & 9.8 & 3.3 \\
\hline Short-term borrowing & 741.3 & 648.5 & 676.6 & 690.3 & 704.0 & 707.5 & 706.6 & 706.3 \\
\hline Public sector \& Central Bank of Ireland & 63.4 & 69.0 & 115.0 & 107.8 & 109.0 & 108.9 & 111.0 & 113.6 \\
\hline Central Bank of Ireland 3/ & 44.4 & 53.5 & 102.0 & 102.0 & 102.0 & 102.0 & 102.0 & 102.0 \\
\hline Public sector 4/ & 19.0 & 15.5 & 13.0 & 5.8 & 7.0 & 6.9 & 9.0 & 11.6 \\
\hline Banks & 566.3 & 493.2 & 468.5 & 494.1 & 506.6 & 510.2 & 498.4 & 485.6 \\
\hline Corporates & 111.6 & 86.4 & 93.1 & 88.4 & 88.4 & 88.4 & 97.3 & 107.0 \\
\hline Financing Gap & 0.0 & 0.0 & 5.8 & 37.1 & 19.7 & 5.0 & 0.0 & 0.0 \\
\hline EU/Bilateral loans & $\ldots$ & $\ldots$ & 0.0 & 28.6 & 13.1 & 3.3 & $\ldots$ & $\ldots$ \\
\hline IMF & $\ldots$ & $\ldots$ & 5.8 & 8.5 & 6.6 & 1.7 & $\ldots$ & $\ldots$ \\
\hline in percent of quota & $\ldots$ & $\ldots$ & 598 & 877 & 676 & 170 & $\ldots$ & $\ldots$ \\
\hline
\end{tabular}

Sources: National authorities, and staff estimates and projections.

$1 /$ No official data on external debt amortization is currently available, as the majority of the data is collected from respondents on a net basis (debt issuances minus debt redemption).

2/ Includes budget deficit financing.

3/ Includes liabilities to Eurosystem related to TARGET (e.g. ECB repo transactions).

4/ Includes market instruments and trade credits. 
Table 7. Ireland: Monetary Survey, 2005-10

\begin{tabular}{|c|c|c|c|c|c|c|}
\hline & 2005 & 2006 & 2007 & 2008 & \multicolumn{2}{|c|}{20092010 (Oct.) } \\
\hline Assets & 941.9 & $1,178.1$ & $1,337.4$ & $1,412.2$ & $1,323.6$ & $1,246.6$ \\
\hline Domestic credit & 349.6 & 450.8 & 481.8 & 532.6 & 505.3 & 472.6 \\
\hline Credit to the private sector & 250.5 & 306.6 & 363.7 & 358.1 & 328.6 & 279.9 \\
\hline Credit to the government & 1.0 & 1.1 & 1.0 & 1.3 & 1.3 & 22.8 \\
\hline Credit to other financial institutio & 98.2 & 143.2 & 117.0 & 173.1 & 175.4 & 169.9 \\
\hline Credit to nonresidents & 241.2 & 298.2 & 334.9 & 362.5 & 339.0 & 395.5 \\
\hline Euro area & 91.8 & 102.6 & 109.0 & 111.0 & 84.7 & 159.9 \\
\hline Rest of world & 149.4 & 195.7 & 225.9 & 251.5 & 254.2 & 235.6 \\
\hline Other assets & 351.0 & 429.1 & 520.6 & 517.1 & 479.4 & 378.5 \\
\hline Liabilities & 941.9 & $1,178.1$ & $1,337.4$ & $1,412.2$ & $1,323.6$ & $1,246.6$ \\
\hline Domestic deposits & 246.0 & 314.8 & 302.7 & 351.1 & 358.3 & 340.8 \\
\hline Deposits from non-residents & 251.1 & 317.4 & 386.3 & 398.9 & 384.1 & 329.6 \\
\hline Euro area & 218.9 & 277.3 & 341.4 & 356.9 & 324.9 & 272.5 \\
\hline Rest of world & 32.3 & 40.1 & 45.0 & 42.0 & 59.2 & 57.1 \\
\hline Other liabilities & 391.3 & 483.3 & 574.0 & 588.6 & 491.1 & 489.7 \\
\hline Capital and reserves & 53.5 & 62.5 & 74.4 & 73.7 & 90.0 & 86.4 \\
\hline Resident & 32.3 & 40.1 & 45.0 & 42.0 & 59.2 & 57.1 \\
\hline \multirow[t]{2}{*}{ Non-Resident } & 21.2 & 22.5 & 29.4 & 31.7 & 30.8 & 29.3 \\
\hline & \multicolumn{6}{|c|}{ (Percent of GDP) } \\
\hline Domestic credit & 215.4 & 254.2 & 254.4 & 295.9 & 316.5 & 301.8 \\
\hline o.w. Credit to the private sector & 154.3 & 172.9 & 192.1 & 199.0 & 205.8 & 178.7 \\
\hline Domestic deposits & 151.6 & 177.5 & 159.8 & 195.0 & 224.4 & 217.6 \\
\hline Memorandum items: & \multicolumn{6}{|c|}{ (Percent) } \\
\hline Capital to assets (In percent) & 5.7 & 5.3 & 5.6 & 5.2 & 6.8 & 6.9 \\
\hline
\end{tabular}

Source: Central Bank of Ireland. 
Table 8. Ireland: Schedule of Reviews and Purchases

\begin{tabular}{|c|c|c|c|c|}
\hline \multirow[t]{2}{*}{ Review } & \multirow[t]{2}{*}{ Availability Date } & \multirow[t]{2}{*}{ Action } & \multicolumn{2}{|c|}{ Purchase } \\
\hline & & & SDRs & Percent of Quota \\
\hline & December 10, 2010 & Board approval of arrangement & $5,012,425,200$ & 597.9 \\
\hline First Review & March 15, 2011 & Observance of end-December 2010 performance criteria, completion of First Review & $1,839,127,000$ & 219.4 \\
\hline Second Review & June 15, 2011 & Observance of end-March 2011 performance criteria, completion of Second Review & $1,839,127,000$ & 219.4 \\
\hline Third Review & September 15, 2011 & Observance of end-June 2011 performance criteria, completion of Third Review & $1,839,127,000$ & 219.4 \\
\hline Fourth Review & December 15, 2011 & Observance of end-September 2011 performance criteria, completion of Fourth Review & $1,839,127,000$ & 219.4 \\
\hline Fifth Review & March 15, 2012 & Observance of end-December 2011 performance criteria, completion of Fifth Review & $1,417,209,700$ & 169.0 \\
\hline Sixth Review & June 15, 2012 & Observance of end-March 2012 performance criteria, completion of Sixth Review & $1,417,209,700$ & 169.0 \\
\hline Seventh Review & September 15, 2012 & Observance of end-June 2012 performance criteria, completion of Seventh Review & $1,417,209,700$ & 169.0 \\
\hline Eight Review & December 15, 2012 & Observance of end-September 2012 performance criteria, completion of Eight Review & $1,417,209,700$ & 169.0 \\
\hline Ninth Review & March 15, 2013 & Observance of end-December 2012 performance criteria, completion of Ninth Review & $357,007,000$ & 42.6 \\
\hline Tenth Review & June 15, 2013 & Observance of end-March 2013 performance criteria, completion of Tenth Review & $357,007,000$ & 42.6 \\
\hline Eleventh Review & September 15, 2013 & Observance of end-June 2013 performance criteria, completion of Eleventh Review & $357,007,000$ & 42.6 \\
\hline Twelth Review & November 15, 2013 & Observance of end-September 2013 performance criteria, completion of Twelth Review & $357,007,000$ & 42.6 \\
\hline Total & & & $19,465,800,000$ & 2321.8 \\
\hline
\end{tabular}

Source: IMF staff projections. 
Table 9. Ireland. Indicators of Fund Credit, 2010-24 1/

(In millions of SDR)

\begin{tabular}{|c|c|c|c|c|c|c|c|c|c|c|c|c|c|c|c|}
\hline & 2010 & 2011 & 2012 & 2013 & 2014 & 2015 & 2016 & 2017 & 2018 & 2019 & 2020 & 2021 & 2022 & 2023 & 2024 \\
\hline \multicolumn{16}{|l|}{ Prospective Fund credit } \\
\hline Disbursement & 5,012 & 7,356 & 5,669 & 1,428 & - & - & - & - & - & - & - & - & - & - & - \\
\hline Stock 2/ & 5,012 & 12,369 & 18,038 & 19,466 & 19,466 & 18,324 & 16,026 & 12,960 & 9,716 & 6,472 & 3,227 & 1,125 & 179 & - & - \\
\hline Obligations & 25 & 214 & 443 & 574 & 758 & 1,911 & 3,005 & 3,662 & 3,704 & 3,562 & 3,420 & 2,152 & 959 & 180 & 0 \\
\hline Repurchase & - & - & - & - & - & 1,142 & 2,298 & 3,066 & 3,244 & 3,244 & 3,244 & 2,102 & 947 & 179 & - \\
\hline Charges & 25 & 214 & 443 & 574 & 758 & 769 & 707 & 596 & 460 & 318 & 176 & 49 & 12 & 2 & 0 \\
\hline \multicolumn{16}{|l|}{ Stock of prospective Fund credit } \\
\hline In percent of quota & 598 & 1,475 & 2,151 & 2,322 & 2,322 & 2,186 & 1,912 & 1,546 & 1,159 & 772 & 385 & 134 & 21 & - & - \\
\hline In percent of GDP & 3.7 & 9.0 & 12.8 & 13.3 & 12.7 & 11.4 & 9.5 & 7.3 & 5.2 & 3.3 & 1.6 & 0.5 & 0.1 & - & - \\
\hline In percent of exports of goods and services & 3.8 & 8.8 & 12.0 & 12.3 & 11.6 & 10.3 & 8.5 & 6.6 & 4.7 & 3.0 & 1.4 & 0.5 & 0.1 & - & - \\
\hline \multicolumn{16}{|l|}{ Obligations to the Fund from prospective EFF } \\
\hline In percent of quota & 3 & 26 & 53 & 69 & 90 & 228 & 358 & 437 & 442 & 425 & 408 & 257 & 114 & 22 & 0 \\
\hline In percent of GDP & 0.0 & 0.2 & 0.3 & 0.4 & 0.5 & 1.2 & 1.8 & 2.1 & 2.0 & 1.8 & 1.7 & 1.0 & 0.4 & 0.1 & 0 \\
\hline In percent of exports of goods and services & 0.0 & 0.2 & 0.3 & 0.4 & 0.5 & 1.1 & 1.6 & 1.9 & 1.8 & 1.6 & 1.5 & 0.9 & 0.4 & 0.1 & 0 \\
\hline
\end{tabular}

1/ Calculated based on full disbursements of the available amounts under the proposed extended arrangement under the Extended Fund Facility. 2/ End of period. 


\section{Appendix I. Debt Sustainability Analysis}

\section{Public sector debt}

Starting from a low level, general government debt has increased rapidly during the crisis. At the onset of the crisis, in 2007, the fiscal position was in surplus and general government debt was only 25 percent of GDP. Following a sharp contraction in GDP, deterioration in the fiscal position, and large bank support outlays, the debt ratio is expected to reach 99 percent by end- 2010 .

In the baseline scenario, debt is expected to peak at 125 percent of GDP in 2013. The combination of low growth and inflation, a high fiscal deficit, and additional bank support will continue to weigh on public indebtedness in the medium term.

- Growth is expected to average $2 \frac{1 / 4}{4}$ percent over $2011-14$, and inflation is expected to remain below other euro area countries.

- With the fiscal consolidation laid out in the authorities' National Recovery Plan for 2011-14, the primary balance is expected to improve from a deficit of $9 \frac{1}{2}$ percent in 2010 (excluding bank support), to a 11/2 percent of GDP surplus in 2015.

The debt dynamics will depend on the amounts drawn down for bank recapitalization. Although it is anticipated that the notional amount designated for bank support under the program ( $€ 35$ billion) will not be used, the baseline scenario incorporates the cautious assumption that $€ 17.5$ billion available to the authorities under the overall EU-IMF program is drawn for this purpose (with the other half provided from the authorities own resources). The baseline thus defines the most conservative debt trajectory. Debt dynamics would improve if the stress tests (and diagnostics) or liability management lower the financing needs for bank recapitalization. Thus, if $€ 25$ billion were used, debt would peak at 119 percent of GDP in 2013, and if only the initial $€ 10$ billion were used, debt would peak at 109 percent of GDP. Each of these scenarios assumes notionally that one half is financed by the authorities' liquid assets, and the remainder from the resources available under the overall EU-IMF financial package. The implication also is that if the amounts needed for recapitalization are smaller, the government can use its liquid assets to cover the budgetary financing need or repay debt.

Economic recovery and fiscal consolidation would put the debt ratio on a downward path after 2013, but risks remain. However, risks to the baseline scenario are substantial, as illustrated by alternative scenarios and bound tests:

- With a standardized permanent shock to growth the debt ratio would reach 155 percent of GDP by 2015 and not stabilize. The calibration of the shock is severe $(1 / 2$ historical 
standard deviation $-2 \frac{1}{2}$ percentage points lower growth than in the baseline scenario), given the large output volatility in Ireland.

- In the absence of fiscal consolidation, debt would continue to increase. In a standardized scenario with the primary balance at its 2010 level (excluding bank support), the debt ratio would reach 159 percent of GDP by 2015 .

- The debt trajectory furthermore remains vulnerable to interest rate developments. Should interest rates be $1 \frac{1}{2}$ percentage points higher, the debt ratio would stabilize at 132 percent.

\section{External debt}

Ireland gross external liabilities are very large in relation to GDP, but these are mostly offset by external assets. Ireland's gross non-resident liabilities are large at 1,057 percent of GDP (as of end-March 2010). But this due mainly to the presence of a large international financial services (IFSC) industry, which also possesses sizeable external assets. Indeed, a more comprehensive measure of Irish external liabilities is the International Investment Position (IIP). ${ }^{1}$ According to this measure, when holdings of foreign assets are taken into consideration, the Irish external position is a net liability of circa 90 percent of GDP.

External public sector liabilities have increased. Since end-September 2008, gross external liabilities of credit institutions (both IFSC and non-IFSC) and money market fundsprimarily with a short-term maturity - have been declining. In contrast, the public sector (including general government and monetary authority) has been accumulating external liabilities. In particular, the gross external debt of the Central Bank of Ireland - related to liabilities to the European System of Central Banks (ESCB)—reached $€ 38.1$ billion as of end-March 2010. While public gross external debt at about 120 percent of GDP is just over 10 percent of all external debt, IIP data indicate that public sector is now responsible for 55 percent of total net external liabilities.

\section{Under the baseline scenario, gross external debt is expected to peak at 1,096 percent of GDP in 2011, but decline to 972 percent of GDP by end-2015. The baseline scenario incorporates the assumption that the full amount of the EU-IMF financing will be drawn, partly contributing to a buildup in Irish foreign assets (about $€ 19$ billion). Under the baseline projections, public sector external liabilities will continue to increase, while deleveraging will lower private sector liabilities. Public sector external debt is expected to peak at 154 percent of GDP in 2013, two years later than total external debt.}

\footnotetext{
${ }^{1}$ International Investment Position accounts cover all external liabilities, including those arising from transactions in equity and derivate contracts.
} 
As illustrated by alternative scenarios and bound tests, risks to the baseline scenario are non-negligible even though external debt sustainability does not appear to be jeopardized:

- With a permanent shock to growth, the external debt ratio would reach 1,116 percent of GDP by 2015 and peak two years later than under the baseline scenario. The external debt-to-GDP ratio will still stabilize, in spite of the severity of the shock $\left(-2 \frac{1}{2}\right.$ percentage points lower growth than in the baseline scenario).

- $\quad$ The debt trajectory remains particularly vulnerable to exchange rate developments. Should the real exchange rate depreciate by 30 percent in 2010 , debt would reach 1,546 percent of GDP by 2011, to decline to 1,370 percent by 2015 . 
Gross external liabilities are large, but mostly offset by external assets

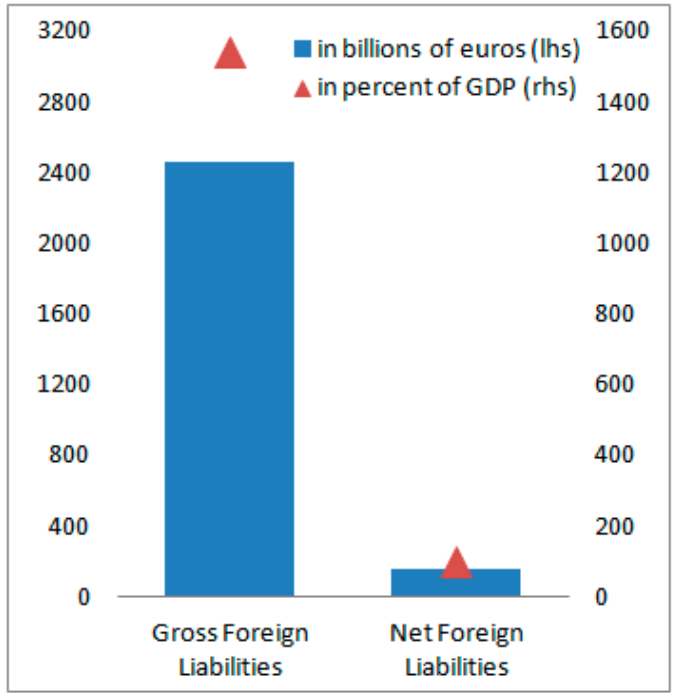

Private sector external debt accounts for over 90 percent of total external liabilities

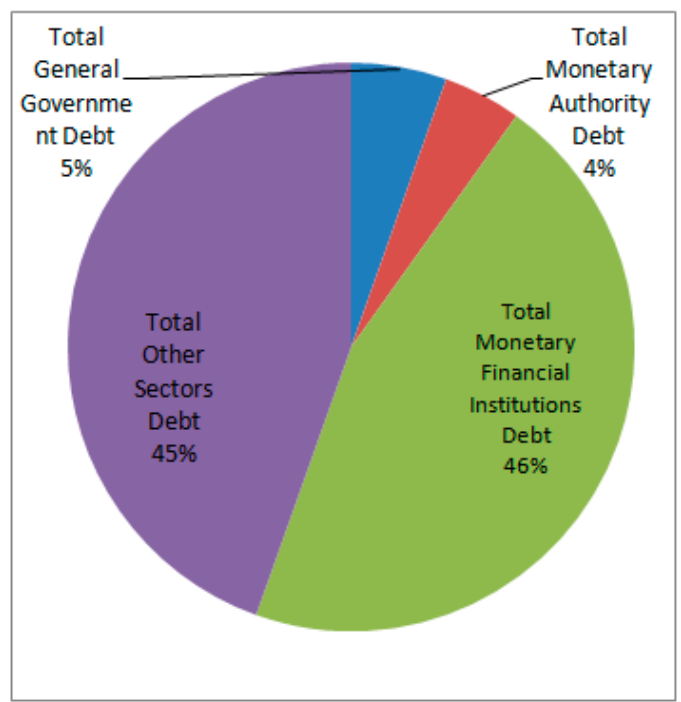

Source: National authorities and staff calculations.
IIP data show that foreign liabilities are mostly due to the presence of international financial services

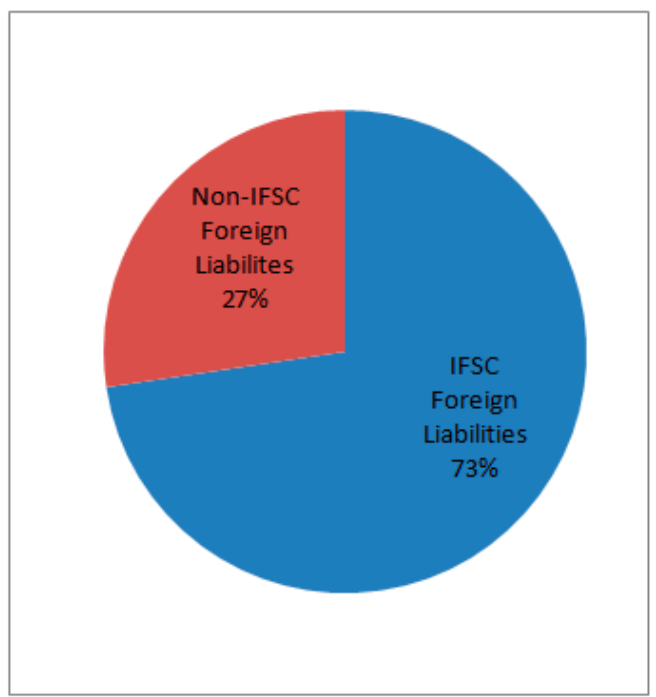

The majority of external liabilities are of short-term maturity

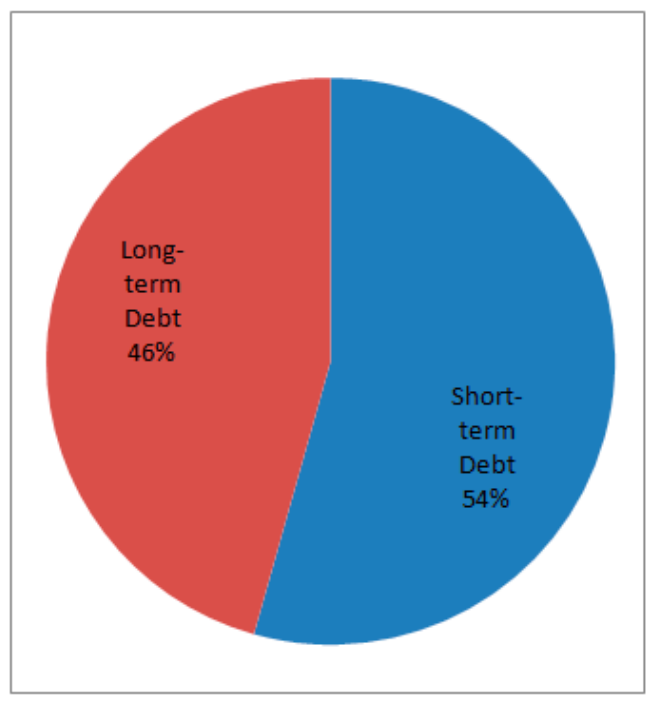


Appendix Table 1. Ireland: Public Sector Debt Sustainability Framework, 2005-2015 (In percent of GDP, unless otherwise indicated)

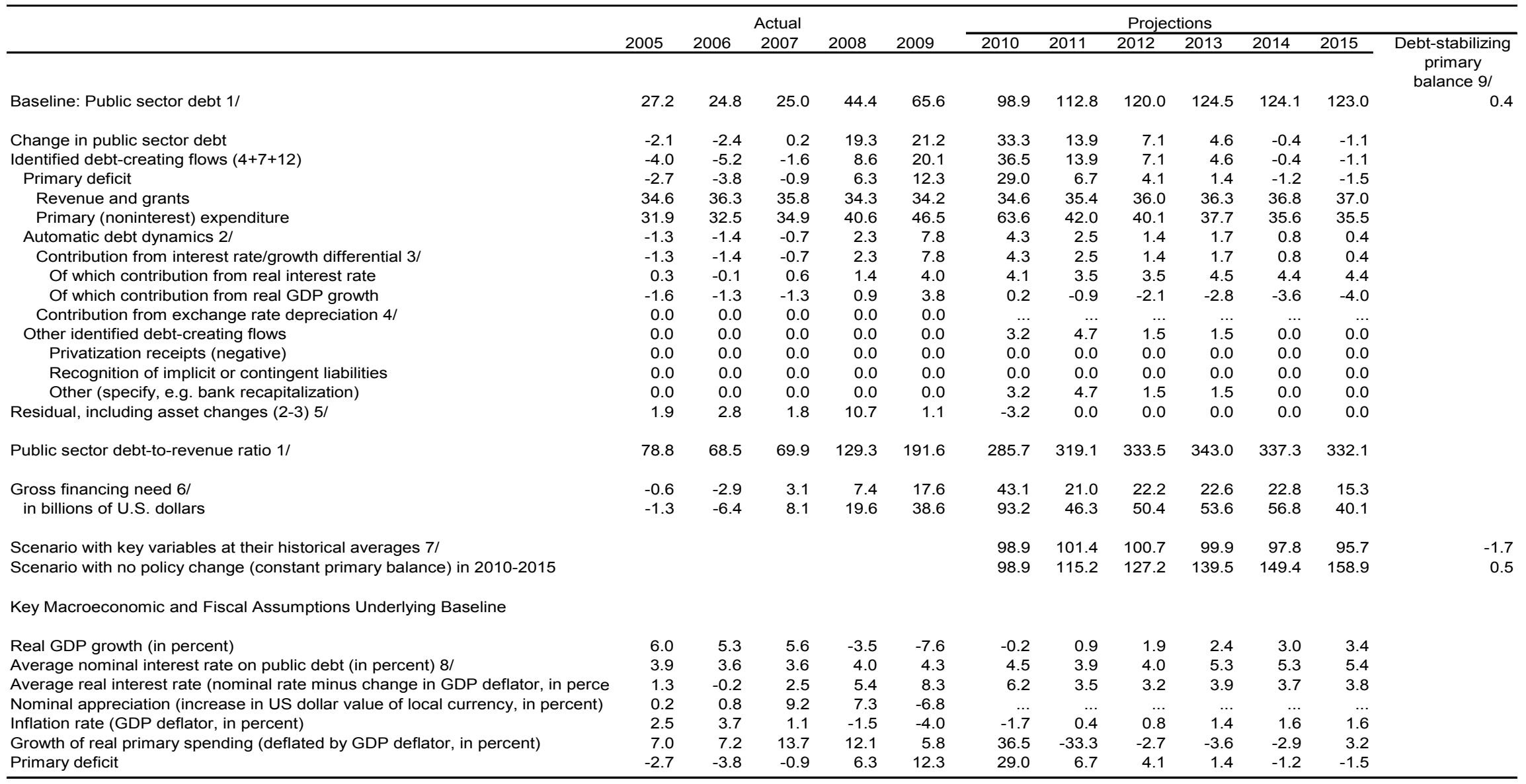

Sources: WEO; and staff estimates.

1/ General government gross debt. The projections include Fund and EU disbursements. Government-guaranteed NAMA bonds are excluded, based on Eurostat guidance.

For 2015, no policy change is assumed.

2/ Derived as $[(r-\pi(1+g)-g+\alpha \varepsilon(1+r)] /(1+g+\pi+g \pi))$ times previous period debt ratio, with $r=$ interest rate; $\pi=$ growth rate of GDP deflator; $g=$ real GDP growth rate; $\alpha=$ share of foreign-currency denominated debt; and $\varepsilon=$ nominal exchange rate depreciation (measured by increase in local currency value of U.S. dollar).

$3 /$ The real interest rate contribution is derived from the denominator in footnote $2 /$ as $r-\pi(1+g)$ and the real growth contribution as $-\mathrm{g}$.

$4 /$ The exchange rate contribution is derived from the numerator in footnote $2 /$ as $\alpha \varepsilon(1+r)$.

5/ For projections, this line includes exchange rate changes.

6/ Defined as public sector deficit, plus amortization of medium and long-term public sector debt, plus short-term debt at end of previous period.

7/ The key variables include real GDP growth; real interest rate; and primary balance in percent of GDP.

8/ Derived as nominal interest expenditure divided by previous period debt stock.

9/ Assumes that key variables (real GDP growth, real interest rate, and other identified debt-creating flows) remain at the level of the last projection year. 


\section{Appendix Figure 1. Ireland: Public Debt Sustainability: Bound Tests 1/ (Public debt in percent of GDP)}

Baseline and historical scenarios

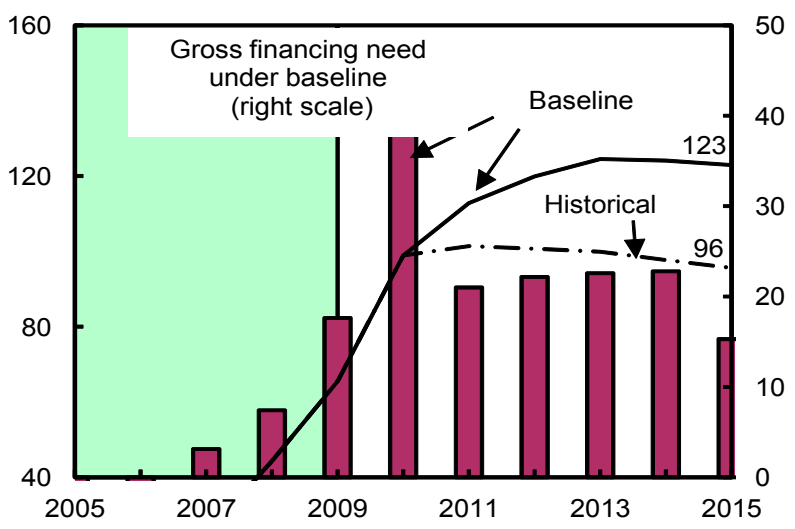

Growth shock (in percent per year)

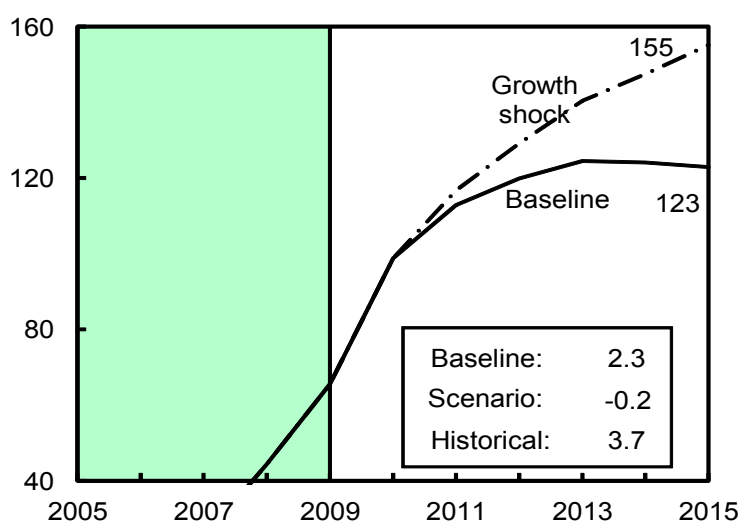

Combined shock 2/

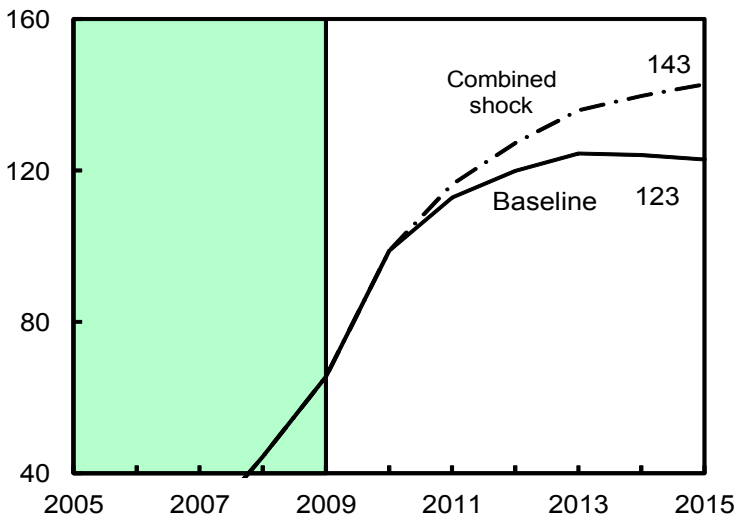

Interest rate shock (in percent)

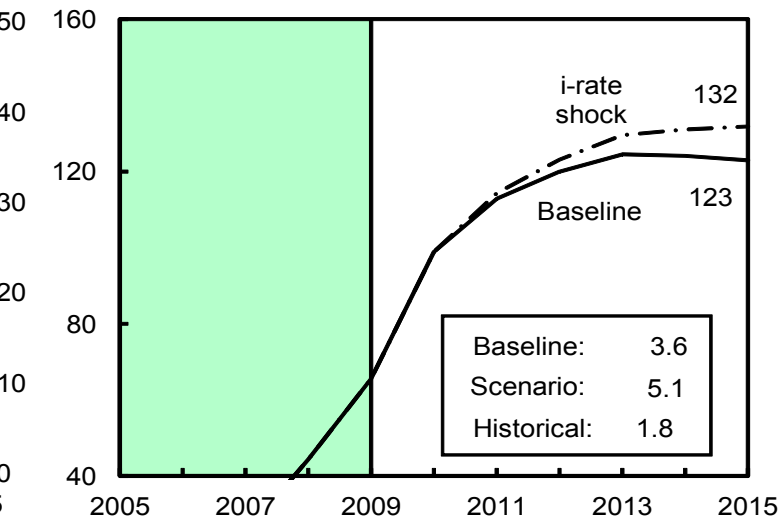

Primary balance shock and no policy change scenario (constant primary balance)

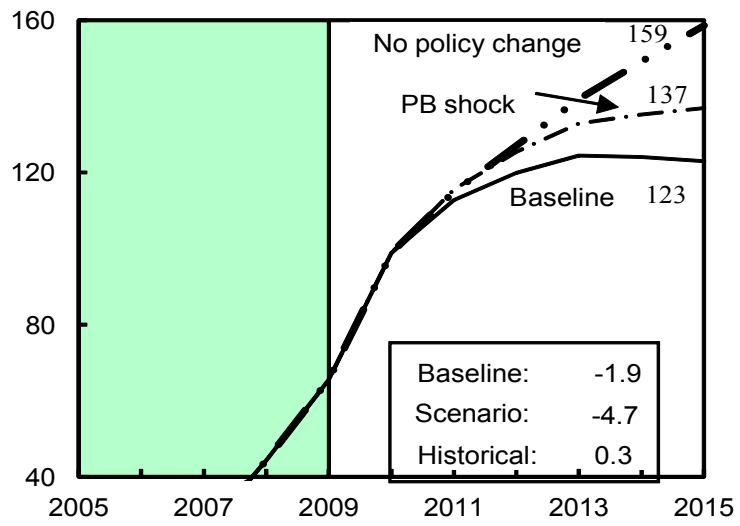

Real depreciation and contingent liabilities shocks 3/

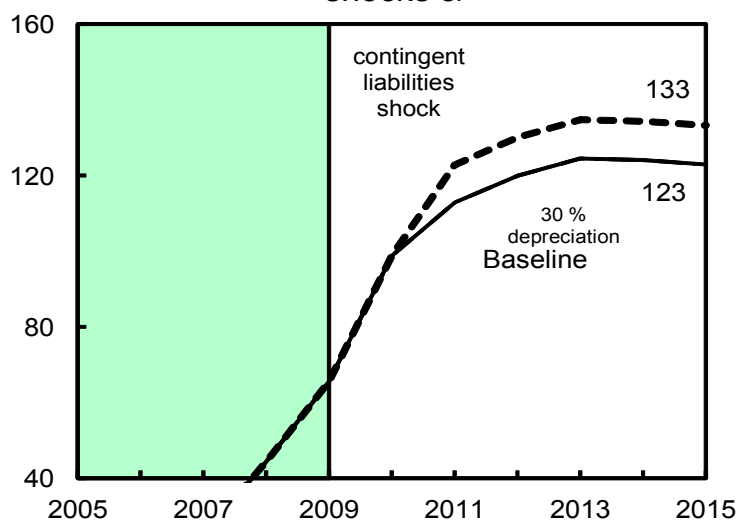

Sources: International Monetary Fund, country desk data, and staff estimates.

1 / Shaded areas represent actual data. Individual shocks are permanent one-half standard deviation shocks. Figures in the boxes represent average projections for the respective variables in the baseline and scenario being presented. Ten-year historical average for the variable is also shown.

$2 /$ Permanent $1 / 4$ standard deviation shocks applied to real interest rate, growth rate, and primary balance.

$3 /$ One-time real depreciation of 30 percent and 10 percent of GDP shock to contingent liabilities occur in 2010, with real depreciation defined as nominal depreciation (measured by percentage fall in dollar value of local currency) minus domestic inflation (based on GDP deflator). 
Appendix Table 2. Ireland: External Debt Sustainability Framework, 2005-2015 (In percent of GDP, unless otherwise indicated)

\begin{tabular}{|c|c|c|c|c|c|c|c|c|c|c|c|c|}
\hline & \multicolumn{5}{|c|}{ Actual } & \multicolumn{6}{|c|}{ Projections } & \multirow{2}{*}{$\begin{array}{l}\text { Debt- } \\
\text { stabilizing non- } \\
\text { interest current } \\
\text { account }\end{array}$} \\
\hline & 2005 & 2006 & 2007 & 2008 & 2009 & 2010 & 2011 & 2012 & 2013 & 2014 & 2015 & \\
\hline Baseline: External debt & 697.8 & 754.9 & 813.3 & 940.4 & 1036.9 & 1084.9 & 1096.5 & 1086.6 & 1059.1 & 1016.3 & 971.7 & -17.1 \\
\hline Change in external debt & 152.5 & 57.1 & 58.4 & 127.1 & 96.5 & 48.0 & 11.6 & -9.9 & -27.5 & -42.7 & -44.6 & \\
\hline Identified external debt-creating flows $(4+8+9)$ & -58.2 & -90.5 & -140.6 & -14.8 & 172.2 & -2.8 & -11.2 & -15.4 & -26.7 & -30.3 & -32.7 & \\
\hline Current account deficit, excluding interest payments & -12.5 & -20.5 & -24.3 & -28.2 & -21.0 & -25.9 & -31.7 & -30.4 & -28.6 & -27.1 & -25.7 & \\
\hline Deficit in balance of goods and services & -11.7 & -10.3 & -9.9 & -9.0 & -15.0 & -19.0 & -22.4 & -23.8 & -24.7 & -25.5 & -25.9 & \\
\hline Exports & 80.6 & 79.1 & 80.3 & 82.8 & 90.0 & 97.4 & 101.8 & 105.0 & 107.0 & 108.5 & 109.5 & \\
\hline Imports & 69.0 & 68.8 & 70.4 & 73.8 & 75.0 & 78.3 & 79.3 & 81.2 & 82.4 & 82.9 & 83.6 & \\
\hline Net non-debt creating capital inflows (negative) & -17.1 & -29.9 & -38.6 & -4.1 & -10.7 & -8.0 & -2.2 & 4.9 & -1.5 & 0.1 & 0.0 & \\
\hline Automatic debt dynamics $1 /$ & -28.6 & -40.1 & -77.7 & 17.5 & 203.9 & 31.1 & 22.6 & 10.0 & 3.4 & -3.3 & -7.0 & \\
\hline Contribution from nominal interest rate & 16.0 & 24.1 & 29.6 & 33.8 & 24.0 & 28.4 & 32.8 & 30.5 & 29.0 & 27.6 & 26.2 & \\
\hline Contribution from real GDP growth & -30.1 & -33.7 & -36.4 & 28.3 & 84.9 & 2.8 & -10.2 & -20.5 & -25.6 & -30.9 & -33.2 & \\
\hline Contribution from price and exchange rate changes $2 /$ & -14.4 & -30.4 & -70.8 & -44.6 & 95.0 & & & & & & & \\
\hline Residual, incl. change in gross foreign assets (2-3) $3 /$ & 210.6 & 147.6 & 199.0 & 141.9 & -75.7 & 50.8 & 22.8 & 5.5 & -0.8 & -12.4 & -11.9 & \\
\hline External debt-to-exports ratio (in percent) & 865.2 & 954.2 & 1013.1 & 1136.1 & 1152.3 & 1114.0 & 1077.6 & 1035.2 & 989.4 & 937.0 & 887.4 & \\
\hline $\begin{array}{l}\text { Gross external financing need (in billions of US dollars) } 4 \text { / } \\
\text { in percent of GDP }\end{array}$ & $\begin{array}{l}524.2 \\
259.3\end{array}$ & $\begin{array}{l}689.7 \\
309.7\end{array}$ & $\begin{array}{l}777.2 \\
299.4\end{array}$ & $\begin{array}{l}941.5 \\
355.4\end{array}$ & $\begin{array}{r}1180.3 \\
530.8\end{array}$ & $\begin{array}{r}1037.4 \\
506.6\end{array}$ & $\begin{array}{r}1002.5 \\
492.1\end{array}$ & $\begin{array}{r}1001.8 \\
481.2\end{array}$ & $\begin{array}{r}1010.9 \\
470.1\end{array}$ & $\begin{array}{r}1009.8 \\
450.9\end{array}$ & $\begin{array}{l}979.1 \\
418.2\end{array}$ & \\
\hline Scenario with key variables at their historical averages $5 /$ & & & & & & 1084.9 & 995.3 & 911.4 & 830.9 & 746.9 & 667.3 & -53.6 \\
\hline \multicolumn{13}{|l|}{ Key Macroeconomic Assumptions Underlying Baseline } \\
\hline Real GDP growth (in percent) & 6.0 & 5.3 & 5.6 & -3.5 & -7.6 & -0.2 & 0.9 & 1.9 & 2.4 & 3.0 & 3.4 & \\
\hline GDP deflator in US dollars (change in percent) & 2.7 & 4.6 & 10.4 & 5.8 & -9.2 & -7.7 & -1.4 & 0.3 & 0.8 & 1.1 & 1.1 & \\
\hline Nominal external interest rate (in percent) & 3.2 & 3.8 & 4.6 & 4.2 & 2.1 & 2.5 & 3.0 & 2.8 & 2.8 & 2.7 & 2.7 & \\
\hline Growth of exports (US dollar terms, in percent) & 6.7 & 8.0 & 18.3 & 5.2 & -8.7 & -0.3 & 3.9 & 5.4 & 5.3 & 5.5 & 5.5 & \\
\hline Growth of imports (US dollar terms, in percent) & 10.3 & 9.9 & 19.2 & 7.0 & -14.7 & -3.8 & 0.7 & 4.5 & 4.9 & 4.8 & 5.4 & \\
\hline Current account balance, excluding interest payments & 12.5 & 20.5 & 24.3 & 28.2 & 21.0 & 25.9 & 31.7 & 30.4 & 28.6 & 27.1 & 25.7 & \\
\hline Net non-debt creating capital inflows & 17.1 & 29.9 & 38.6 & 4.1 & 10.7 & 8.0 & 2.2 & -4.9 & 1.5 & -0.1 & 0.0 & \\
\hline
\end{tabular}

$1 /$ Derived as $[r-g-r(1+g)+e a(1+r)] /(1+g+r+g r)$ times previous period debt stock, with $r=$ nominal effective interest rate on external debt; $r=$ change in domestic GDP deflator in US dollar terms, $\mathrm{g}=$ real GDP growth rate, $\mathrm{e}=$ nominal appreciation (increase in dollar value of domestic currency), and $\mathrm{a}=$ share of domestic-currency denominated debt in total external debt.

2/ The contribution from price and exchange rate changes is defined as $[-\mathrm{r}(1+\mathrm{g})+\mathrm{ea}(1+\mathrm{r})] /(1+\mathrm{g}+\mathrm{r}+\mathrm{gr})$ times previous period debt stock. $\mathrm{r}$ increases with an appreciating domestic currency $(\mathrm{e}>0)$ and rising inflation (based on GDP deflator).

$3 /$ For projection, line includes the impact of price and exchange rate changes.

4/ Defined as current account defict, plus amortization on medium- and long-term debt, plus short-term debt at end of previous period.

5/ The key variables include real GDP growth; nominal interest rate; dollar deflator growth; and both non-interest current account and non-debt inflows in percent of GDP. 
Appendix Figure 2. Ireland: External Debt Sustainability: Bound Tests 1/

(Gross external debt in percent of GDP, unless otherwise specified)

Baseline and historical scenarios

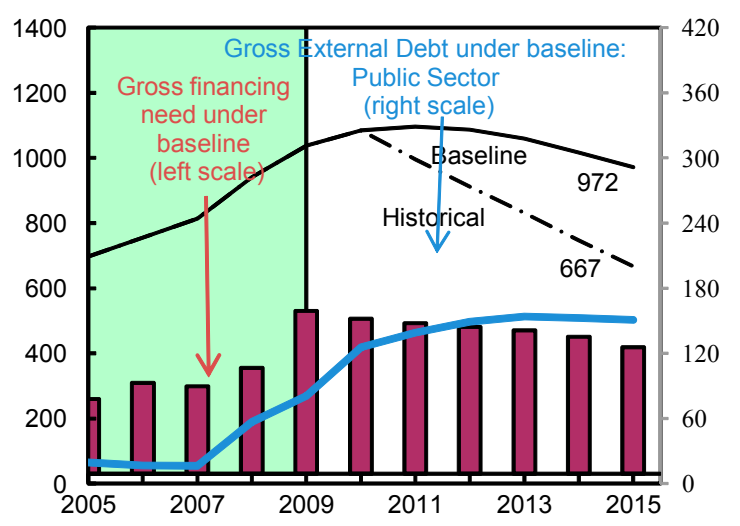

Growth shock (in percent per year)

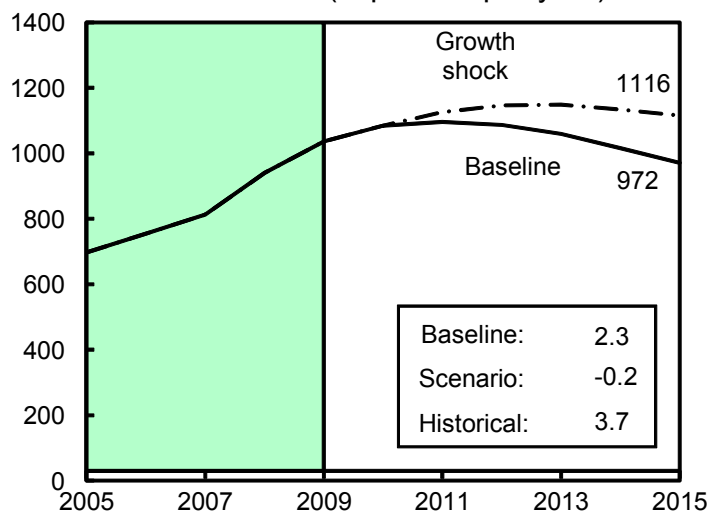

Combined shock 2/

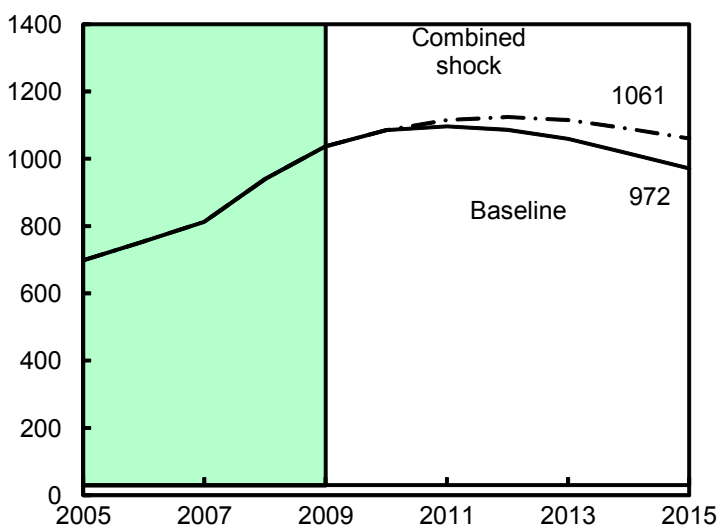

Interest rate shock (in percent)

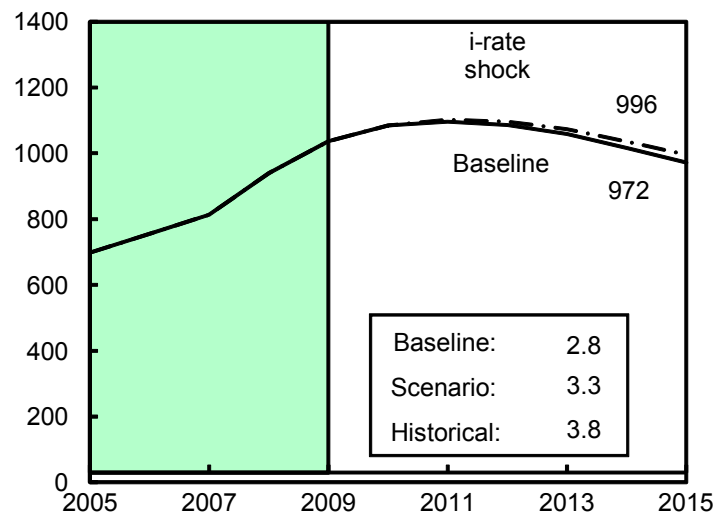

Non-interest current account shock (in percent of GDP)

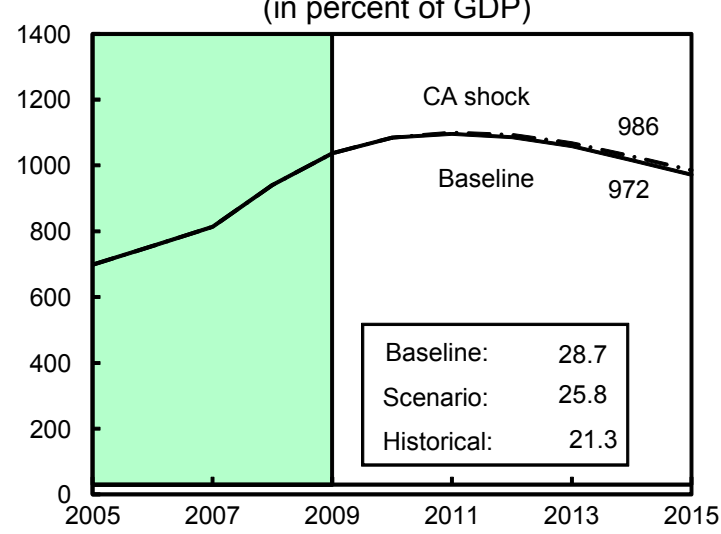

Real depreciation shock $3 /$

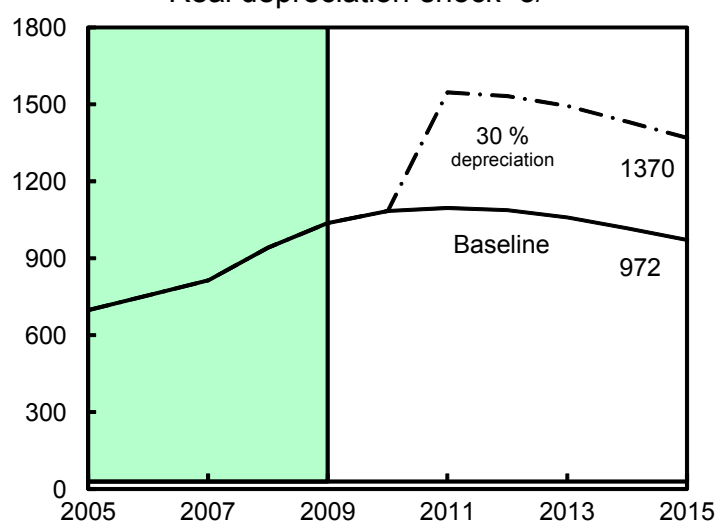

Sources: International Monetary Fund, Country desk data, and staff estimates.

$1 /$ Shaded areas represent actual data. Individual shocks are permanent one-half standard deviation shocks. Figures in the boxes represent average projections for the respective variables in the baseline and scenario being presented. Ten-year historical average for the variable is also shown.

2/ Permanent 1/4 standard deviation shocks applied to real interest rate, growth rate, and current account balance.

3/ One-time real depreciation of 30 percent occurs in 2010. 
Dublin, December 3, 2010

Mr. Dominique Strauss-Kahn

Managing Director

International Monetary Fund

Washington, DC 20431

Dear Mr. Strauss-Kahn:

1. Ireland faces an economic crisis without parallel in its recent history. The problems of low growth, doubts about fiscal sustainability, and a fragile banking sector are now feeding on each other, undermining confidence. To break this vicious circle, we are proposing a strong, wide-ranging, reform programme, backed by a substantial international financing package, to restore confidence and return the economy to a path of sustained growth and job creation.

2. At the root of the problem is a domestic banking system, which at its peak was five times the size of the economy, and now is under severe pressure. The Irish owned banks were much larger than the size of the economy. The fragility of the banking sector is undermining Ireland's hard-earned economic credibility and adding a severe burden to acute public finance challenges. Decisive actions to restore the strength of the financial sector and reestablish fiscal credibility are needed now.

3. The Irish authorities have already undertaken major steps to address these challenges. For the financial sector, these include measures to facilitate funding of banks, separate good assets from bad, asset disposals, and bank recapitalisation. On the fiscal side, we have pursued a large consolidation programme since 2008 and have announced a National Recovery Plan that accelerates the process of putting public finances on a sound footing.

4. But we recognise that more needs to be done. A fundamental downsizing and reorganisation of our banking system is essential. We are immediately undertaking several bold measures to achieve a robust, smaller, and better capitalised banking system that will effectively serve the needs of the economy. Restoring the banks to viability will also help insulate public finances from further pressures. We are mindful that the transition to a healthy banking sector will need to be actively managed to avoid fire sales of assets and reduce market uncertainty. We are, therefore, expeditiously raising capital standards, stepping up efforts that will ensure that banks losses are promptly recognised, and creating a mechanism to inject needed capital into the banks. We are also strengthening the banking resolution framework to promote financial stability. 
5. In addition, we are also pressing ahead with our commitment to achieving a sustainable budget position. The National Recovery Plan lays out our strategy for staying the course of needed reform in a way that is socially fair and protects the most vulnerable. Recognising that Ireland already has put in place a business-friendly environment, our Plan also lays out a range of structural reforms that will be implemented to underpin economic stability, and enhance growth and job creation.

6. We are turning to our international partners for support as we implement these farreaching objectives. Our estimate is that the financing need would be up to $€ 85$ billion until the end of 2013. We therefore request that the Fund support our policy programme through an arrangement under the Extended Fund Facility which can be drawn over a period of 36 months in the amount of SDR 19.4658 billion ( $€ 22.5$ billion). This arrangement, along with support of $€ 45$ billion from the European Financial Stability Mechanism/European Financial Stability Facility including bilateral loans from the United Kingdom, Sweden and Denmark, and the judicious use of our own resources ( $€ 17.5$ billion), will help ensure financial stability as we restore market confidence and return to durable growth.

7. The attached Memorandum of Economic and Financial Policies outlines the economic and financial policies that the Irish authorities will implement during the remainder of 2010 and the period 2011-13. We are confident that the policies set forth in this memorandum are adequate to achieve the objectives under the programme. We stand ready to take any corrective actions that may become appropriate for this purpose as circumstances change. As is standard under Fund-supported programmes, we will consult with the Fund on the adoption of such actions in advance of necessary revision of policies contained in this letter.

8. This letter is being copied to Messrs. Juncker, Reynders, Rehn, and Trichet.

Sincerely,

/s/

Brian Lenihan
Minister for Finance /s/

Patrick Honohan

Governor of the Central Bank of Ireland 


\section{Attachment I. Memorandum of Economic and Financial Policies}

1. We have concluded that Ireland expeditiously requires a strong programme to restore domestic and external confidence and, thus, snap the pernicious feedback loops between the growth, fiscal, and financial crises.

2. We propose that such a programme comprise of four key elements:

- A fundamental downsizing and reorganisation of the banking sector-complemented by the availability of capital to underpin solvency - is required to restore confidence. Addressing market perceptions of weak bank capitalisation, overhauling the banks' funding structure, and immediately beginning a process of downsizing the banking system will be required.

- $\quad$ An ambitious fiscal consolidation building, on the progress already made.

- $\quad$ Renewing growth through a multi-pronged effort.

- A substantial external financial assistance will support the achievement of our policy objectives.

\section{Recent Economic Developments and Outlook}

3. After two years of sharp declines in output, the Irish economy is expected to broadly stabilise this year before expanding during 2011-14. As domestic imbalances from the boom years are being repaired, the recovery will, at least initially, be primarily export-driven. We project that GDP growth will increase over time as export performance filters through to investment and consumption, consumer confidence returns, and labour market conditions improve. We recognise that the risks in the short term are tilted to the downside, and, in particular, the headwinds from fiscal consolidation on domestic demand could be larger than anticipated. Over the longer haul also, continued private and public sector balance sheet adjustments, coupled with a weak banking sector, could delay the recovery.

4. Inflation is expected to remain low, reflecting the large output gap and modest external price pressures. Although the inflation rate will likely increase over time, it is expected to remain lower than in trading partner countries. This will have the benefit of improving competitiveness but the low rates of inflation would unavoidably keep real debt burdens high and dampen domestic demand.

5. The current account balance is projected to continue to improve gradually over the medium term, reflecting export expansion and the contraction in domestic demand. However, profit repatriation from multinationals and large interest payments to foreign holders of Irish debt are expected to limit the improvement over the programme period. 


\section{Restoring Financial Sector Viability}

6. With its large size relative to the economy, its heavy reliance on wholesale funding, and its large exposures to the real estate sector, much of the domestic Irish banking system is in a stressed state. The Government has intervened heavily to safeguard financial stability. In late 2009, we established the National Asset Management Agency (NAMA) to take over certain vulnerable commercial and property development assets of banks. In addition, major efforts have been made to boost banks' capital.

7. Although the Government has made strong efforts to contain the fallout from the sector's vulnerabilities, a continued lack of market access and the loss of deposits have created significant funding pressures, alleviated largely by an increase in recourse to Eurosystem financing facilities and Emergency Liquidity Assistance by the Central Bank. Moreover, capital injections in the banks have placed a heavy burden on public finances.

8. Our proposed programme will take decisive steps to ensure the viability and health of the financial system. We intend to lay the foundations of this process very quickly, if we are to reassure the markets that banks will return to viability and will have the ability to operate without further state support in a reasonable period of time.

9. The key component of our efforts is an overhaul of the financial sector with the objective of substantial downsizing, isolating the non-viable parts of the system and returning the sector to healthy functionality. It will be important to support this process through capital injections into viable financial institutions. In addition, structural measures - a special resolution scheme for deposit-taking institutions and a further strengthening of the supervisory system - will impart greater stability to the system. It is our goal that the leaner and more robust system that emerges from these efforts will not be dependent on state support, will have a more stable funding base, and will provide the credit required to foster growth.

10. The plan to overhaul the banking system has several elements. First, banks will be required to run down non-core assets. Second, land and development property loans that have not yet been transferred to NAMA will also be transferred. Third, banks will be required to promptly and fully provide for all non-performing assets as needed. Fourth, the banks will be required to securitise and/or sell asset portfolios or divisions with credit enhancement if needed, once the market normalises. And finally, swift and decisive action will be taken to resolve the position of Anglo Irish Bank (Anglo) and Irish Nationwide Building Society (INBS) in a way that protects depositors and strengthens the banking system. To this end, by end-January 2011, we will submit to the European Commission a revised proposal developed in collaboration with IMF to resolve Anglo and INBS. Each of these initiatives will require technical or legislative measures, most of which we believe can be expeditiously instituted.

11. To achieve the above goals, banks will be required to submit deleveraging plans to the national authorities by end-February 2011. The plans will be prepared on the basis of clear periodic targets defined by the Central Bank, taking into consideration the Prudential 
Liquidity Assessment Review (PLAR) to be conducted in consultation with the EC, ECB and IMF. By end-March 2011, the Central Bank with assistance from an internationally recognised consulting firm, will complete the assessment of the banks' restructuring plans (structural benchmark). The deleveraging plans will be a component of the restructuring plans to be submitted to the European Commission for approval under EU competition rules.

12. This reorganisation and downsizing of the banks will be bolstered by raising capital standards. While we expect that, in a restructured system, banks will be able to raise capital in the market, we recognise that the higher standards may imply that, in the short run, public provision of capital will be needed for banks that are deemed to be viable. To support this process - and to render it credible - we will undertake a review of the capital needs of banks on the basis of a diagnostic of current asset valuations and stringent stress tests (PCAR 2011).

- As an immediate step, to enhance confidence in the solvency of the banking system, the Central Bank will direct Allied Irish Bank (AIB), Bank of Ireland (BoI), and EBS to achieve a capital ratio of 12 percent core tier 1 by end-February 2011 (structural benchmark) and Irish Life \& Permanent by end-May 2011 (structural benchmark). This would imply an injection of fresh equity capital of $€ 7 \mathrm{bn}$ into these four banks and provide an additional buffer for a potential increase in expected losses. This action, along with early measures to support deleveraging and taking account of haircuts on the additional loans to be transferred to NAMA(see 910$)$ would result in an injection of $€ 10 \mathrm{bn}$ of fresh capital into the banking system, above and beyond the already committed capital injection of $€ 6.6 \mathrm{bn}$ for AIB previously announced by the Irish authorities.

- $\quad$ By end-December 2010, in consultation with EC, ECB, and IMF staff, we will define the criteria to run stringent stress test scenarios (structural benchmark). We will also agree with EC, ECB, and IMF staff, by end-December 2010, on draft terms of reference for the due diligence of bank assets by internationally recognised consulting firms (structural benchmark). We intend to complete the diagnostic evaluation of banks' assets by end-March 2011 and the stress tests (PCAR 2011) by endMarch 2011 (both structural benchmarks), and transparently communicate our findings.

- $\quad$ Based on these assessments, starting end-April 2011, banks will be required to maintain a core tier 1 capital ratio of 10.5 percent. Banks will report their capital adequacy ratios to the Central Bank on a quarterly basis. The Central Bank's assessment of banks' capital adequacy ratio will be made public at least semiannually.

13. The question of whether burden should be imposed on bank sub debt is influenced by two factors: the quantum of capital the State has committed to support the institution and the perceived viability of the bank in the absence of receiving such capital. Forced burden sharing through legislation is possible and legislation is currently being prepared in this 
regard. Alternatively, in certain cases, a very deeply discounted liquidity management exercise might also be an appropriate option.

14. In addition, we will finalise proposals to strengthen the legal framework for dealing with distressed deposit-taking institutions in line with recent EU developments (including EU competition rules) and international sound practices. Such a special resolution regime will broaden the available resolution tools with the aim of promoting financial stability and protecting depositors. In particular, the draft legislation will (i) provide for the appointment of a special manager where, in the opinion of the Central Bank, an institution's financial condition has severely deteriorated; (ii) grant powers to the Central Bank for the transfer of assets and liabilities to other institutions; and (iii) create a framework for the establishment of bridge banks. We seek to submit draft legislation including the above mentioned elements to Dáil Éireann by end-February 2011 (structural benchmark).

15. Moreover, we will continue the efforts to strengthen banking supervision by ensuring higher staffing levels and budget allocations in line with OECD best practices. We will enhance the risk assessment framework and raise the corporate governance standards. By end-September 2011, a report by an independent assessor on our compliance with Basel core principles for effective banking supervision will be made public.

16. We will also reform the personal insolvency regime for financially responsible individuals (including sole traders), which will balance the interests of both creditors and debtors. The objectives will be to lower the cost and increase the speed and efficiency of proceedings, while at the same time mitigating moral hazard and maintaining credit discipline. The new legal framework will include a non-judicial debt settlement and enforcement mechanism as an alternative to court-supervised proceedings.

17. We will continue to provide means-tested financial assistance to limit the economic and social fallout of the crisis. The existing mortgage interest supplement scheme is crucial for providing temporary assistance to distressed mortgage holders. The scheme's administration will be centralised to ensure a more consistent application focusing on households that are most in need, and further modification will be introduced in the 2011 Social Welfare Act.

18. Our strategy for the credit union sector is based on three components. First, we will complete a full assessment of their loan portfolios by end-April 2011 (structural benchmark). Second, by end-April 2011, we will have ready a comprehensive strategy to enhance the viability of the sector. And third, by end-December 2011 we will submit legislation to Dáil Éireann to assist the credit unions with a strengthened regulatory framework including effective governance and stabilisation requirements.

19. We will continue efforts to ensure the flow of credit to viable businesses, building on actions already taken under previous recapitalisations and NAMA legislation. Allied Irish Banks and Bank of Ireland have agreed, in connection with recapitalisation last March, to make available not less than $€ 3$ billion each for targeted lending for new or increased credit 
facilities to small and medium-sized enterprises in both 2010 and 2011 as well as funds for seed and venture capital and for Environmental lending. The lending policies and decisions of both banks are subject to review by the Credit Review Office, which enables businesses who have had credit refused or withdrawn, to apply for an independent review of the bank's decision.

20. NAMA is subject to an extensive range of statutory Governance and Accountability arrangements and these will be fully adhered to. Members of the NAMA Board must have relevant experience and expertise, and the work of the Board is supported by audit and other sub-committees. NAMA operations are also subject to statutory codes of practice. NAMA is required to prepare various reports, including quarterly reports of its activities, and these are subject to scrutiny by Oireachtas committees. The Comptroller and Auditor General audit the annual accounts and prepare reports on NAMA for review by the Public Accounts committee.

\section{Safeguarding Public Finances}

21. To continue with the programme of fiscal consolidation, a comprehensive National Recovery Plan 2011-14 was approved by the Government and published on 24 November 2010. This Plan forms the basis for the 2011 budget consistent with fiscal consolidation measures amounting to $€ 15$ billion, a 9 percent of GDP budgetary correction over the period 2011-14. Having stabilised the deficit, albeit at a high level, the steps announced in the Plan will place the budget deficit-to-GDP ratio on a firm downward path. While the debt-to-GDP ratio will remain at high levels for the next few years, it is projected to decline thereafter, underpinning debt sustainability. We also propose to keep under review progress towards meeting the Stability and Growth Pact targets.

22. Budget 2011 which will include adjustment measures of $€ 6$ billion, will be submitted to the Dáil Éireann for passage on 7 December (prior action). As set out in the National Recovery Plan, most of this adjustment will come from the expenditure side. The capital budget will be reduced, partly through greater value for money in our infrastructure procurements. On current expenditures, we are pursuing public service numbers reductions through natural attrition and voluntary schemes, adjustments in public service pensions, and further savings on social transfers (from reductions in working age payments, reductions in universal child benefit payments and other reforms). Protecting the socially vulnerable at a time of difficult economic adjustment remains a central policy goal. Current savings will also be realised from streamlining government programmes and through administrative efficiencies. Should these savings or the expected numbers reductions not materialise, we reserve the option to take further measures.

23. An income tax-led revenue package - sized at over $€ 2$ billion in a full year-will supplement the above expenditure measures in 2011. Over the past decade, the proportion of citizens exempt from income tax has risen to 45 percent and tax credits have doubled, 
resulting in a comparatively low burden of tax on ordinary incomes. This is no longer sustainable. Accordingly, we are widening the tax base, by lowering income tax bands and credits by 10 percent, and by reducing various pension-related tax reliefs. We are also taking action on other tax expenditures, and distortions arising from the existence of multiple levies.

24. To secure our fiscal targets, a number of fiscal measures have been identified for 2012-14. We will continue to rely on expenditure savings ( $€ 6.1$ billion), led by current spending ( $€ 4.9$ billion), as outlined in the National Recovery Plan. We are targeting further reductions in public sector numbers, social benefits and programme spending, and have anchored the prospective savings by publishing multi-year expenditure ceilings by Vote Group through 2014. We are also planning to move towards full cost-recovery in the provision of water services and ensuring a greater student contribution towards tertiary education, while ensuring that lower-income groups remain supported. In addition, we will accelerate the process of placing the pension systems on a path consistent with long-term sustainability of public finances. On the tax side, we will build on the base-broadening measures outlined above and establish a sound basis for sub-national finances through a new residential-property based site value tax. The Finance Bill 2012 will contain necessary provisions to bring into effect the already signalled VAT increases in 2013 and 2014.

25. We are preparing institutional reform of the budget system taking into account anticipated reforms of economic governance at the EU level. A reformed Budget Formation Process will be put in place. Furthermore, we will introduce a Fiscal Responsibility Law which will include provision for a medium-term expenditure framework with binding multiannual ceilings on expenditure in each area by end-July 2011 (structural benchmark). A Budget Advisory Council, to provide an independent assessment of the Government's budgetary position and forecasts will also be introduced by end-June 2011 (structural benchmark). These important reforms will enhance fiscal credibility and anchor long-term debt sustainability.

\section{Raising the Growth Potential}

26. We recognise the need to restore strong sustainable growth. The structural changes to the financial and fiscal sectors, described above, are critical for improving the prospects of economic recovery and raise the medium-term growth potential. Although, as is widely recognised, Ireland is a global leader in providing a business-friendly environment, the National Recovery Plan includes a strategy to remove remaining structural impediments to competitiveness and employment creation. It also details appropriate sectoral policies to encourage exports and a recovery of domestic demand, which will also support growth and promote jobs.

27. Specifically, we will continue to press ahead with other structural reform as set out in the Memorandum of Understanding on specific economic policy conditionality:

- We will promote service sector growth through vigorous action to remove remaining restrictions on trade and competition, and will propose amendments to legislation to 
enable the imposition of financial and other sanctions in civil law cases relating to competition.

- $\quad$ Building on the forthcoming report of the Review Group on State Assets \& Liabilities the government will undertake an independent assessment of the electricity and gas sectors with a view to enhancing their efficiency. State authorities will consult with the Commission Services on the results of this assessment with a view to setting appropriate targets for the possible privatisation of state-owned assets.

- $\quad$ To reduce long-term unemployment and to facilitate re-adjustment in the labour market, we will reform the benefits system and legislate to reform the national minimum wage. Specifically, changes will be introduced to create greater incentives to take up employment.

\section{Programme Financing}

28. Ireland is facing large and medium-term balance of payments needs that arise from (i) substantial pressures on the capital account that need to be relieved, and (ii) the need to build-up reserves to improve banks' ability to meet their large external debt rollover needs. The programme's success is dependent on substantive external financial assistance. This external financing will serve as a bridge during the implementation of the critical reforms to fundamentally restructure the banking system and restore fiscal sustainability. It is our view that, given Ireland's medium-term structural adjustment needs, an arrangement under the Extended Fund Facility (EFF) would be appropriate. Such an arrangement would also have the added benefit of a more realistic repayment schedule for Ireland.

29. Notwithstanding the large fiscal adjustment, we estimate the financing need to be up to $€ 85$ billion until the end of 2013. This includes a contingency element for bank recapitalisation. An amount of $€ 17.5$ billion will be covered by an Irish contribution through the Treasury cash buffer and investments of the National Pension Reserve Fund. We expect commitments from the IMF under the Extended Arrangement to amount to $€ 22.5$ billion and EU financial support from the European Financial Stability Mechanism/European Financial Stability Facility and bilateral arrangements to amount to $€ 45$ billion. Ireland will draw on these resources in parallel throughout the programme period. While the envelope of resources to be provided to Ireland is a source of reassurance to the authorities and to financial markets, we plan to draw pari passu on IMF and EU financial support on an as needed basis. Moreover, if market access is restored on a sustainable basis, we would anticipate paying down the drawings made on an advanced schedule.

30. We are confident that the implementation of the fiscal and banking sector reforms will help the economy recover. 


\section{Programme Monitoring}

31. Progress in the implementation of the policies under the programme will be monitored through quarterly and continuous performance criteria, indicative targets, structural benchmarks, and quarterly programme reviews and compliance with requirements under the Excessive Deficit Procedure (EDP). The attached Technical Memorandum of Understanding (TMU) defines the quantitative performance criteria and indicative targets under the programme. The Government's targets for the exchequer balance (central government cash balance) excluding interest payments will be monitored through quarterly performance criteria and net central government debt will be an indicative target (Table 1). As is standard in IMF arrangements, there will be a continuous performance criterion on the non-accumulation of external payment arrears. Progress on implementing structural reforms will be monitored through structural benchmarks (Table 2). A joint EC-ECB Memorandum of Understanding specifies, notably, the structural policies recommended in the MEFP, and sets a precise time frame for their implementation.

32. As is standard in all Fund arrangements, a safeguards assessment of the Central Bank of Ireland will be completed by the first review of the arrangement. In this regard, the Central Bank will receive a safeguards mission from the Fund and provide the information required to complete the assessment by the first review. As a related matter, and given that financing from the IMF will be used to provide direct budget support, a framework agreement will be established between the government and the Central Bank of Ireland on their respective responsibilities for servicing financial obligations to the IMF. As part of these arrangements, Fund disbursements will be deposited into the government's account at the Central Bank.

33. We authorise the IMF and the European Commission to publish the Letter of Intent and its attachments, and the related staff report. 
Table 1. Ireland: Quantitative Performance Criteria and Indicative Targets under the Economic Programme for 2010-11

\begin{tabular}{|c|c|c|c|c|c|}
\hline & December 31, 2010 & March 31, 2011 & June 30, 2011 & September 30, 2011 & December 31, 2011 \\
\hline & \multicolumn{5}{|c|}{ (In billions of Euros) } \\
\hline & $\begin{array}{l}\text { Performance } \\
\text { Criterion }\end{array}$ & $\begin{array}{l}\text { Performance } \\
\text { Criterion }\end{array}$ & $\begin{array}{l}\text { Indicative } \\
\text { Target }\end{array}$ & Indicative Target & Indicative Target \\
\hline $\begin{array}{l}\text { 1. Cumulative exchequer primary } \\
\text { balance } 1 /\end{array}$ & -15.3 & -7.8 & -11 & -14.3 & -14.6 \\
\hline \multirow{2}{*}{$\begin{array}{l}\text { 2. Ceiling on the accumulation of } \\
\text { new external payments arrears on } \\
\text { external debt contracted or } \\
\text { guaranteed by the central } \\
\text { government } 2 /\end{array}$} & 0 & 0 & 0 & 0 & 0 \\
\hline & Indicative Target & Indicative Target & $\begin{array}{l}\text { Indicative } \\
\text { Target }\end{array}$ & Indicative Target & Indicative Target \\
\hline $\begin{array}{l}\text { 3. Ceiling on the stock of central } \\
\text { government net debt }\end{array}$ & 83.1 & 91.6 & 96.5 & 100 & 102.2 \\
\hline
\end{tabular}

1/ Measured by the exchequer balance excluding interest payments. Cumulative from the start of the relevant calendar year. 2/ Applies on a continuous basis. 
Table 2. Prior Action and Structural Benchmarks Under the Economic Programme for 2010-11

\section{Measure}

Submit the 2011 Budget to Dáil Éireann (MEFP, \22).

Define the criteria to run stringent stress tests scenarios (MEFP $\mathbb{1 1 2}$ ).

Agree on terms of reference for the due diligence of bank assets by internationally recognised consulting firms (MEFP, $\mathbb{\Upsilon 1} 12$ ).

The Central Bank will direct the recapitalisation of the principal banks (AIB, Bol and EBS) to achieve a capital ratio of 12 percent core tier 1 (MEFP, \$12).

Submit to Dáil Éireann the draft legislation on a special resolution regime (MEFP, \14).

The Central Bank to complete the assessment of the banks' restructuring plans (MEFP, \11).

Complete the diagnostic evaluation of banks' assets (MEFP, ๆ12).

Complete stress tests (PCAR 2011) (MEFP, \12).

Complete a full assessment of credit unions' loan portfolios (MEFP, $\mathbb{\Upsilon 1 8}$ ).

The Central Bank will direct the recapitalisation of ILP to achieve a capital ratio of 12 percent core tier 1 (MEFP, \12).

Establish a Budget Advisory Council. (MEFP, \25).

Introduce a medium-term expenditure framework with binding multi-annual ceilings on expenditure in each area (MEFP, \25).
7 December 2010

End-December 2010

Structural Benchmark

End-December 2010

Structural Benchmark

End-February 2011 Structural Benchmark

End-February 2011 Structural Benchmark

End-March $2011 \quad$ Structural Benchmark

End-March 2011

Structural Benchmark

End-March 2011

Structural Benchmark

End-April 2011

Structural Benchmark

End-May 2011

Structural Benchmark

End-June 2011

Structural Benchmark

End-July 2011

Structural Benchmark 


\title{
AtTaChment II. TeChnical Memorandum OF Understanding (TMU)
}

\author{
December 1, 2010
}

1. This Technical Memorandum of Understanding (TMU) sets out the understandings regarding the definitions of the indicators subject to performance criteria and indicative targets under the arrangement supported by the Extended Fund Facility (EFF). These performance criteria and indicative targets are reported in Table 1 attached to the Memorandum of Economic and Financial Policies (MEFP). This TMU also describes the methods to be used in assessing the programme performance and the information requirements to ensure adequate monitoring of the targets.

2. For programme purposes, all foreign currency-related assets, liabilities, and flows will be evaluated at "programme exchange rates", with the exception of the items affecting the government fiscal balances, which will be measured at current exchange rates. The programme exchange rates are those that prevailed on November 24, as shown on the European Central bank web-page, in particular, $€ 1=1.3339$ U.S. dollar and $€ 1=0.86547$ SDR.

\section{Quantitative Performance Criteria And Indicative Targets}

\section{A. Floor on the Exchequer Primary Balance}

3. The exchequer balance is the traditional domestic budgetary aggregate which measures the net surplus or net deficit position of the Exchequer Account. The Exchequer Account is the single bank account of the Central Fund and is held at the Central Bank of Ireland. The annual audited accounts of the Exchequer Account produced by the Department of Finance are known as the Finance Accounts. An unaudited summary known as the Exchequer Statement is produced at the end of each month. Under the Irish Constitution, all Government receipts are paid in to the Central Fund and all Government expenditure is funded from it, unless provided otherwise by law. ${ }^{1}$ The Exchequer balance is the difference between total receipts into, and total expenditure out of, the Exchequer Account. It measures the sum of the current and capital balances. The current balance is defined as current receipts (tax and non-tax revenue) minus current expenditure (voted expenditure and non-voted expenditure charged directly on the Central Fund, including the Sinking Fund). The capital balance is defined as capital receipts (Sinking Fund and other capital receipts) minus capital

\footnotetext{
${ }^{1}$ Receipts of the Central Fund comprise Exchequer tax revenues, non-tax revenues, receipts from the European Union and other capital receipts. Charges on the Central Fund include the expenditure of Government departments and offices, payments related to the servicing of the national debt, payments to the European Union Budget, the salaries, pensions and allowances of the President, judiciary, and Comptroller \& Auditor General and the running costs of the Houses of the Oireachtas (Parliament). Extra-budgetary funds (including the National Pensions Reserve Fund), the Social Insurance Fund, semi-state bodies and local governments are not part of the Exchequer system.
} 
expenditure (voted and non-voted expenditure). The Sinking Fund provision is a transfer from the current account to the capital account to reduce national debt and has no effect on the overall exchequer balance.

4. The performance criteria are set on the exchequer primary balance (the exchequer balance excluding net debt interest payments in the service of the National Debt $)^{2}$.

5. For the purposes of the programme, the floor on the exchequer primary balance (quantitative performance criterion) will be adjusted downward by payments for bank restructuring carried out under the programme's banking sector support and restructuring strategy. Such payments may include, inter alia, loans to banks, investments in their equity (requited recapitalisation), unrequited recapitalisation, and purchases of troubled assets, which are carried out in line with programme objectives. Any other financial operation by Government to support banks, including the issuance of guarantees or provision of liquidity, will be reported to IMF staff.

6. The floor on the exchequer primary balance (quantitative performance criterion) in each year will be measured cumulatively from the start of that calendar year.

\begin{tabular}{cc}
\hline Cumulative Exchequer primary balance & (In billions of Euros) \\
\hline From January 1, 2010: & -15.3 \\
End-December 2010 (performance criterion) & -7.8 \\
From January 1, 2011: & -11.0 \\
End-March 2011 (performance criterion) & -14.3 \\
End-June 2011 (indicative target) & -14.6 \\
End-September 2011 (indicative target) & \\
End-December 2011 (indicative target)
\end{tabular}

7. The performance criterion on the exchequer primary balance (floor) for end-March 2011 and thereafter, will be adjusted upward (downward) for the full amount of any over-performance (under-performance) in Exchequer tax revenues, pay-related social insurance contributions (PRSI), health levy and national training fund contributions against the current projection which is listed below ${ }^{3}$ :

\begin{tabular}{lc}
\hline $\begin{array}{l}\text { Cumulative Exchequer tax revenue \& other receipts (as } \\
\text { outlined in 7. above) }\end{array}$ & (In billions of Euros) \\
\hline End-March 2011 (projection) & 9.7 \\
End-June 2011 (projection) & 19.4 \\
End-September 2011 (projection) & 29.7 \\
End-December 2011 (projection) & 41.9 \\
\hline
\end{tabular}

8. Any policy changes, including in tax administration and enforcement, which impact the above revenue projection will lead to a reassessment of the adjustor in the context of program reviews.

\footnotetext{
${ }^{2}$ Net debt interest payments are as per the end-month Exchequer Statements.

${ }^{3}$ Exchequer tax receipts are comprised of income tax, value added tax (VAT), corporation tax, excise duties, stamp duties, capital gains tax, capital acquisitions tax and customs duties.
} 


\section{B. Ceiling on the Stock of Central Government Net Debt}

9. The stock of central government net debt, for the purposes of the programme, is defined as the National Debt, less liquid assets of the National Pensions Reserve Fund (NPRF). The National Debt is defined as the total outstanding amount of principal borrowed by central government and not repaid to date, less liquid assets available for redemption of those liabilities at the same date. These liquid assets comprise the Exchequer cash balances (including cash in the Capital Services Redemption Account), Exchequer deposits with commercial banks and other institutions, investments in investment grade sovereign bills. For the purposes of the programme, NPRF liquid assets include the asset classes listed above, and also all marketable securities such as equities, government bonds and other listed investments. NPRF shares in domestic Irish banks are excluded from the definition of liquid assets.

10. For the purposes of the programme, the ceiling on the central government net debt (indicative target) will be adjusted upward by debt arising from payments for bank restructuring carried out under the programme's banking sector support and restructuring strategy. These payments may include, inter alia, loans to banks, investments in their equity (requited recapitalisation); unrequited recapitalisation; and purchases of troubled assets, which are carried out in line with programme objectives. The programme exchange rates will apply to all non-euro denominated debt.

11. The ceiling on the outstanding stock of central government net debt will be adjusted upward (downward) by the amount of any final upward (downward) revision to the stock of end-October 2010 central government net debt.

\begin{tabular}{lc}
\hline Central government net debt & (In billions of Euros) \\
\hline Outstanding stock: & 78.6 \\
End-October 2010 (provisional) & 83.1 \\
End-December 2010 (indicative target) & 91.6 \\
End-March 2011 (indicative target) & 96.5 \\
End-June 2011 (indicative target) & 100.0 \\
End-September 2011 (indicative target) & 102.2 \\
End-December 2011 (indicative target) & \\
\hline
\end{tabular}

\section{Non-accumulation of External Payments Arrears by Central Government}

12. The central government will accumulate no external payments arrears during the programme period. For the purposes of this performance criterion, an external payment arrear will be defined as a payment by the central government on its contracted or guaranteed external debt that has not been made within five business days after falling due. The performance criterion will apply on a continuous basis.

13. The stock of external payments arrears of the central government will be calculated based on the schedule of external payments obligations reported by the National Treasury 
Management Agency. This performance criterion does not cover arrears with regard to trade credits.

\section{REPORTING REQUIREMENTS}

14. Performance criteria under the programme will be monitored using data supplied to the IMF. The Irish authorities will transmit promptly any data revisions in a timely manner.

- The Department of Finance will report the Exchequer balance to the IMF staff, with a lag of no more than seven days after the test date.

- The National Treasury Management Agency will provide provisional figures on the outstanding stock of net government debt with a lag of no more than seven days after the test date. The revised figures will be provided within three months of the test date.

- The National Treasury Management Agency will provide the final stock of the central government system external payments arrears to the IMF staff, with a lag of not more than seven days after the arrears arise in accordance with the definition of external payments arrears as set forth in paragraph 12 of this memorandum. 
Dublin, 3 December, 2010

Mr Jean-Claude Juncker

President

Eurogroup

Mr Didier Reynders

European Union Presidency

Mr Olli Rehn

Commissioner

European Commission

Mr Jean-Claude Trichet

President

European Central Bank

Dear Messrs. Juncker, Reynders, Rehn and Trichet,

1. Ireland faces an economic crisis without parallel in its recent history. The problems of low growth, doubts about fiscal sustainability, and a fragile banking sector are now feeding on each other, undermining confidence. To break this vicious circle, we are proposing a strong, wide-ranging, reform programme, backed by a substantial international financing package, to restore confidence and return the economy to a path of sustained growth and job creation.

2. At the root of the problem is a domestic banking system, which at its peak was five times the size of the economy, and now is under severe pressure. The Irish owned banks were much larger than the size of the economy. The fragility of the banking sector is undermining Ireland's hard-earned economic credibility and adding a severe burden to acute public finance challenges. Decisive actions to restore the strength of the financial sector and re-establish fiscal credibility are needed now.

3. The Irish authorities have already undertaken major steps to address these challenges. For the financial sector, these include measures to facilitate funding of banks, separate good assets from bad, asset disposals, and bank recapitalisation. On the fiscal side, we have pursued a large consolidation programme since 2008 and have announced a National Recovery Plan that accelerates the process of putting public finances on a sound footing.

4. But we recognize that more needs to be done. A fundamental downsizing and reorganisation of our banking system is essential. We are immediately undertaking several bold measures to achieve a robust, smaller, and better capitalised banking system that will effectively serve the needs of the economy. Restoring the banks to 
viability will also help insulate public finances from further pressures. We are mindful that the transition to a healthy banking sector will need to be actively managed to avoid fire sales of assets and reduce market uncertainty. We are, therefore, expeditiously raising capital standards, stepping up efforts that will ensure that banks losses are promptly recognised, and creating a mechanism to inject needed capital into the banks.

5. In addition, we are also pressing ahead with our commitment to achieving a sustainable budget position. The National Recovery Plan lays out our strategy for staying the course of needed reform in a way that is socially fair and protects the most vulnerable. Recognising that Ireland already has put in place a business-friendly environment, our Plan also lays out a range of structural reforms that will be implemented to underpin economic stability, and enhance growth and job creation.

6. We turn to our European and international partners for support as we implement these far-reaching objectives. We therefore request support from the European Financial Stability Mechanism/European Financial Stability Facility which can be drawn down over a period of 36 months as well as bilateral loans from the United Kingdom, Sweden and Denmark; the overall total of this support will be $€ 45$ billion. We also send a parallel request for financial assistance to the IMF for a total amount of $€ 22.5$ billion. The judicious use of our own existing financial resources ( $€ 17.5$ billion) will also help ensure financial stability as we restore market confidence and return to durable growth.

7. The attached Memorandum of Economic and Financial Policies outlines the economic and financial policies that the Irish Government and the Central Bank will implement during the remainder of 2010 and the period 2011-13 to strengthen Ireland's banking sector and fiscal position. An annexed Memorandum of Understanding (MoU) specifies detailed economic policy measures that will serve as benchmarks for assessing policy performance in the context of the quarterly reviews under the financial assistance programmme. We are confident that the policies set forth in these memoranda are adequate to achieve the objectives under the programme. We stand ready to take any corrective actions that may become appropriate for this purpose as circumstances change.

8. The implementation of our programme will be monitored through quantitative performance criteria and structural benchmarks as described in the attached MEFP, and through the detailed and specific economic policy criteria in the MoU. There will be quarterly reviews of the arrangement, in coordination with the IMF. The reviews will assess progress in implementing the programme and reach understandings on any additional measures that may be needed to achieve its objectives.

9. The programme is designed such that it best reflects the interest of Ireland and the international community. We have explored options for the provision of collateral for support under the EFSF and found legal and economic constraints that would risk 
undermining the goals of the programme. The conditionality under the programme provides substantial comfort that the programme will be delivered and that the support will be repaid. We will ensure that the financial assistance in the context of the EFSM and EFSF and bilateral lenders to be provided to Ireland will be subject to the loan terms and conditions that will protect the EU's and the euro-area and EU Member States' financial and legal interests in a non discriminatory way as compared to the assistance provided by the EU to other Member States under its Balance of Payments facility and for the EFSF adapted to take into account its structure and credit enhancement mechanism.

10. The Irish authorities believe that the policies set forth in the attached memorandum are adequate to achieve the objectives of our economic programme, but stand ready to take any further measures that may become necessary for this purpose. The authorities will stay in close contact and consult with the European Commission, the ECB and the IMF on the adoption of these measures and in advance of revisions to the policies contained in the MEFP and the MoU. All available information requested by the European Commission, the ECB and the IMF to assess implementation of the programme will be provided.

We are copying this letter to Mr. Strauss-Kahn, Managing Director of the IMF. Sincerely,

$/ \mathrm{s} /$

Brian Lenihan

Minister for Finance /s/

Patrick Honohan

Governor of the Central Bank of Ireland 


\title{
Ireland \\ Memorandum of Understanding \\ on
}

\section{SPECIFIC ECONOMIC POLICY CONDITIONALITY}

November 28, 2010

\begin{abstract}
The quarterly disbursement of financial assistance from the European Financial Stabilisation Mechanism (EFSM), the European Financial Stability Facility (EFSF) and bilateral loans by UK, Sweden and Denmark will be subject to quarterly reviews of conditionality for the duration of the programme. Release of the instalments will be based on observance of quantitative performance criteria, respect for EU Council Decisions and Recommendations in the context of the excessive deficit procedure, and a positive evaluation of progress made with respect to policy criteria in the Memorandum of Economic and Financial Policies (MEFP) and in this Memorandum of Understanding on specific economic policy conditionality (MoU), which specifies the detailed criteria that will be assessed for the successive reviews up to the end of 2013. If targets are (expected to be) missed, additional action will be taken.

The authorities commit to consult with the European Commission, the ECB and the IMF on the adoption of policies that are not consistent with this Memorandum. They will also provide the European Commission, the ECB and the IMF with all information requested that is available to monitor progress during programme implementation and to track the economic and financial situation. Prior to the release of the instalments, the authorities shall provide a compliance report on the fulfilment of the conditionality.
\end{abstract}

The release of the first instalments will be conditional on the successful adoption of Budget 2011 as described in the MEFP and this MoU.

\section{Actions for the first review (actions to be completed by end Q1-2011)}

\section{i. Fiscal consolidation}

Government submits the draft budget for 2011 for Dáil approval. The budget provides information and prudent projections on the entire general government sector and targets a further reduction of the general government deficit in line with the MEFP. It includes a detailed presentation of fiscal consolidation adjustments for 2011 of $€ 6$ billion.

The budget includes the following measures (in exceptional circumstances, measures yielding comparable savings could be considered in close consultation with European Commission, IMF and ECB staffs); 
- Revenue measures to raise at least $€ 1,400 \mathrm{~m}$ in 2011 and an extra $€ 620 \mathrm{~m}$ in a full year will be introduced to the Houses of the Oireachtas, including:

- A lowering of personal income tax bands and credits or equivalent measures to yield $€ 945 \mathrm{~m}$ in 2011 and an extra $€ 300 \mathrm{~m}$ in a full year.

- A reduction in pension tax relief and pension related deductions to yield $€ 155 \mathrm{~m}$ in 2011 , and an extra $€ 105 \mathrm{~m}$ in a full year.

- A reduction in general tax expenditures to yield $€ 220 \mathrm{~m}$ in 2011, and an extra $€ 185 \mathrm{~m}$ in a full year.

- Excise and miscellaneous tax measures to raise $€ 80 \mathrm{~m}$ in 2011 and a further $€ 30 \mathrm{~m}$ in a full year will be introduced.

- The government will outline methods to raise at least $€ 700 \mathrm{~m}$ in one-off and other measures in 2011.

- A reduction of current expenditure in 2011 of at least $€ 2,090 \mathrm{~m}$ will be implemented including;

- Social Protection expenditure reductions.

- Reduction of public service employment numbers in 2011.

- A reduction of existing public service pensions on a progressive basis averaging over $4 \%$ will be introduced.

- Other expenditure savings of $€ 1,030 \mathrm{~m}$ including savings on goods and services.

- A reduction of at least $€ 1,800 \mathrm{~m}$ in public capital expenditure against existing plans for 2011 will be introduced.

Government will rigorously implement the budget for 2011 and the fiscal consolidation measures announced afterwards, consistent with the requirements of the excessive deficit procedure. Progress is assessed against the (cumulative) quarterly primary deficit ceilings in the Memorandum of Economic and Financial Polices (MEFP) including the Technical Memorandum of Understanding (TMU).

The Department of Finance will continue to ensure tight supervision of expenditure commitments by the line departments, and effective tax collection, to make certain that the primary deficit target in cash (see Table 1 of MEFP) and the general government nominal budget deficit on ESA95 basis as set out in the EU Council Recommendation on excessive deficit procedures are achieved. 


\section{ii. Financial sector reforms}

\section{Recapitalisation measures}

- The measures proposed for the recapitalisation of Irish banks in the government statement of 30 September 2010 will be implemented, taking into account any changes in strategy for the future of the banking sector agreed under the programme.

- Further deleveraging of the banks will be achieved by the extension of the NAMA programme to include approximately $€ 16$ bn of land and development loans in AIB and Bank of Ireland, which had previously been excluded as they were below a value threshold of $€ 20 \mathrm{~m}$. NAMA will categorise sub-€20m AIB and BOI land and development and associated loans (roughly estimated to number 10,000) by reference to asset type and region. NAMA will then apply different discounts to each category based on NAMA's loan valuation experience up to the point of valuation. On this basis it is expected that all loans will be transferred by end-March 2011. NAMA will issue bonds in return for the assets transferred. NAMA will build on the existing outsourcing arrangements with the banks for the management of these smaller loans and performance will be incentivised as appropriate. The NAMA legislation will be amended to underpin the valuation and acquisition of these assets on a portfolio basis. The additional capital requirement will be met by the programme and is included in the figure below. These measures will be notified to the European Commission in accordance with EU competition rules.

- Prudential Capital Assessment Review (PCAR) minimum capital requirement for the Irish banks (AIB, BOI, EBS and ILP) will be set at $10.5 \%$ core tier 1 ;

- In addition the Irish authorities will ensure that AIB, BOI and EBS are initially recapitalised to a level of $12 \%$ core tier 1 capital, which will take account of haircuts on the additional loans to be transferred to NAMA and will fund early deleveraging by making available EUR 10 billion in the system; the recapitalisation will take the form of equity shares (or equivalent instruments for EBS);

- The PCAR exercise will be enhanced to provide a comprehensive evaluation of the underlying assets of the banks, taking into account future expected losses.

- The PCAR for 2011 will be completed based on comprehensive Terms of Reference for its design and implementation, which will have been previously agreed between the Central Bank, the European Commission, IMF and ECB staff. The methodology used will be published in detail. The Commission, IMF and ECB shall be involved in the validation of the PCAR process. In particular, key data and information that relates to the PCAR exercise will be available to the Commission, IMF and ECB upon request.

\section{Deleveraging measures}

- The Central Bank will complete a Prudential Liquidity Assessment Plan (PLAR) for 2011, outlining measures to be implemented with a view to steadily deleveraging the banking system and reducing the banks' reliance on short term funding by the end of the programme period. Ambitious target loan to deposit ratios, to be achieved by end 2013, will be established for each bank by the Irish authorities in consultation with the ECB, EC and the IMF by end Dec 2010. These targets will be designed to ensure that convergence to Basel III standards can be readily met by the relevant dates. To this end, 
the PLAR will establish target funding ratios for 2013 for each of the banks, identify non core assets and set an adjustment path to these targets based on specified non public annual benchmarks. Banks will be informed of necessary actions to be taken so as to comply with the respective funding targets and adjustment paths. The design and implementation of the PLAR will be agreed with the European Commission, the ECB and the IMF. Compliance with the PLAR benchmarks will be monitored and enforced by the Central Bank taking account of prevailing market conditions. The PLAR will be updated on an annual basis.

\section{Reorganisation of banking sector}

- The strategy for the future structure, functioning and viability of Irish credit institutions will be developed in detail and agreed with the European Commission, the ECB and the IMF. Within the context of a comprehensive reorganisation and downsizing of the banking sector the strategy will identify the appropriate path to ensure that the banking system will operate without the need of further State support. The Irish authorities are committed to divest the participations in the banks acquired during the crisis within the shortest timeframe possible which is compatible with financial stability and public finance considerations. Building on restructuring undertaken to date, further restructuring and viability plans for the institutions concerned will be submitted in accordance with EU competition rules; these plans will also be made available to the IMF and ECB. Commitments undertaken by the Irish authorities in the context of EU competition decisions will be maintained.

- In the context of the above strategy, a specific plan for the resolution of Anglo Irish Bank and Irish Nationwide Building Society will be established and submitted to the European Commission in accordance with EU competition rules. Any related legal procedures will be set in motion under a precise timetable. This plan will seek to minimise capital losses arising from the working out of these non-viable credit institutions. The Government will ensure that these credit institutions adhere to the requisite capital ratios.

- Legislation on improved procedures for early intervention in distressed banks and special bank resolution regime (SRR) will be introduced. The SRR should include a robust set of powers and tools to ensure the competent authorities can promptly and effectively resolve distressed banks e.g. when they pose a risk to financial stability. The legislation will be consistent with the EU Treaty rules and will be consistent with similar initiatives ongoing at EU level.

- Central Bank staffing in relation to the PCAR and PLAR exercises will be reviewed and augmented as necessary to guarantee that both exercises can be conducted on a timely and efficient basis.

\section{Burden sharing by holders of subordinated debt}

- Consistent with EU State aid rules, burden sharing will be achieved with holders of subordinated debt in relevant credit institutions over the period of the programme. This will be based on the quantum of capital and other financial assistance the State commits to support specific credit institutions and the financial viability of those institutions in the absence of such support. Resolution and restructuring legislation which will address the 
issue of burden sharing by subordinated bondholders will be submitted to the Oireachtas by end-2010. Where it is appropriate in line with the above criteria, the process of implementing liability management exercises similar to that which is currently being undertaken in relation to holders of subordinated debt in Anglo Irish Bank will be commenced by end-Q1 2011.

\section{iii. Structural reforms}

\section{To facilitate adjustment in the labour market}

The government will introduce legislation to reform the minimum wage in such a way as to foster job creation notably for categories at higher risk of unemployment and prevent distortions of wage conditions across sectors associated with the presence of sectoral minimum wages in addition to the national minimum wage. Measures will be as follows:

- Reduce by $€ 1.00$ per hour the nominal level of the current national minimum wage.

- Enlarge the scope of the "inability to pay clause" permitting firms to invoke this clause more than once;

These measures should come into effect by May 2011.

An independent review of the Framework REA and ERO arrangements will be initiated by the end of Q1 2011. Terms of Reference and follow up actions will be agreed with European Commission Services.

\section{To reduce the risk of long-term unemployment}

The government will reform the unemployment benefit system in such a way as to provide incentives for an early exit from unemployment. This reform of unemployment and social assistance benefits will be part of overall reforms in the welfare system designed to reach budgetary savings of $€ 750 \mathrm{~m}$ in 2011.

Legislative measures will be enacted with a view to:

Taking steps to tackle unemployment and poverty traps including through reducing replacement rates for individuals receiving more than one type of benefit (including housing allowance).

The government reforming the system of activation policies in such a way as to adapt it to the reform in benefits and make it more effective. Legislative and other measures will be introduced with a view to: 
- improving the efficiency of the administration of unemployment benefits, social assistance and active labour market policies, by exploiting synergies and reducing the overlapping of competencies across different departments;

- enhancing conditionality on work and training availability;

- strengthening activation measures via:

i. the introduction of instruments to better identify of job seekers' needs ("profiling") and increased engagement;

ii. a more effective monitoring of jobseekers' activities with regular evidence-based reports;

iii. the application of sanction mechanisms for beneficiaries not complying with jobsearch conditionality and recommendations for participation in labour market programmes set in such a way as to imply an effective loss of income without being perceived as excessively penalising so that it could credibly be used whenever lack of compliance is ascertained.

At each subsequent review of the programme, the government will submit reports containing an assessment (including by means of quantitative indicators) of the management of activation policies and on the outcome of job seekers' search activities and participation in labour market programmes.

Legislative measures should come into effect by May 2011.

An in-depth review of the personal debt regime will be published shortly. Work will commence on reform of legislation which will balance the interests of both creditors and debtors.

\section{Actions for the second review (actions to be completed by end Q2- 2011)}

\section{i. Fiscal consolidation}

Government will rigorously implement the budget for 2011 and the fiscal consolidation measures announced afterwards, consistent with the requirements of the excessive deficit procedure. Progress will be assessed against the (cumulative) quarterly primary deficit ceilings in the Memorandum of Economic and Financial Polices (MEFP) including the Technical Memorandum of Understanding (TMU).

The Department of Finance will continue to ensure tight supervision of expenditure commitments by the line departments, and effective tax collection, to make certain that the primary deficit target in cash (see Table 1 of MEFP) and the general government nominal 
budget deficit on ESA95 basis as set out in the EU Council Recommendation on excessive deficit procedures are achieved.

The government will submit a timetable for implementing the recommendations of the Memorandum. Upon consideration by the European Commission, IMF and ECB staffs the measures in this timetable shall become the performance benchmarks for future reviews.

\section{ii. Financial sector reforms}

- The results of the PCAR for 2011 will be assessed by the authorities, together with the European Commission, the ECB and the IMF. The results will be published in detail and on a bank-by-bank basis.

- Depending on the results of the PCAR 2011, the Government will ensure that the banks are recapitalised in the form of equity, if needed, so as to ensure that the minimum capital requirement of $10.5 \%$ will be maintained.

- Introduce legislation for the enhancement of financial regulation, expanding the supervisory and enforcement powers of the Central Bank.

- The Irish authorities will ensure that ILP is recapitalised to a level of $12 \%$ core tier 1 capital.

- Progress in implementation of the strategy for the reorganisation of Irish credit institutions will be assessed by the authorities, together with the European Commission, the ECB and the IMF.

\section{iii. Structural reforms}

\section{To enhance long-term fiscal sustainability}

- The Authorities undertake to introduce legislation to increase the state pension age. Under the Government's National Pension Framework the age at which people will qualify for the State Pension will be increased to 66 years in 2014, 67 in 2021 and 68 in 2028.

\section{iv. Structural fiscal reforms}

\section{To reinforce a credible budgetary strategy}

- The government will continue to ensure the reliability and the regular availability of budgetary data for both the whole of the general government sector and its breakdown into government layers. Specifically, reporting will comply with the provisions included in annex 1 of the MoU.

- Under the period of this financial assistance programme, any additional unplanned revenues must be allocated to debt reduction. 
- In accordance with the proposal set out in the National Recovery Plan 2011-2014, the government will establish a budgetary advisory council to provide an independent assessment of the Government's budgetary position and forecasts.

- Government extends the voluntary 15 day rule relating to prompt payments to the health service executive, local authorities and state agencies.

\section{Actions for the third review (actions to be completed by end Q3-2011)}

\section{i. Fiscal consolidation}

Government will rigorously implement the budget for 2011 and the fiscal consolidation measures announced afterwards, consistent with the requirements of the excessive deficit procedure. Progress is assessed against the (cumulative) quarterly primary deficit ceilings in the Memorandum of Economic and Financial Polices (MEFP) including the Technical Memorandum of Understanding (TMU).

Government will consider an appropriate adjustment, including to the overall public service wage bill, to compensate for potential shortfalls in the projected savings arising from administrative efficiencies and public service numbers reductions.

The Department of Finance will continue to ensure tight supervision of expenditure commitments by the line departments, and effective tax collection, to make certain that the primary deficit target in cash (see Table 1 of MEFP) and the general government nominal budget deficit on ESA95 basis as set out in the EU Council Recommendation on excessive deficit procedures are achieved.

\section{ii. Financial sector reforms}

- Interim review of progress under PLAR 2011 and any related actions will be assessed, together with the European Commission, the ECB and the IMF.

- Progress in implementing the strategy for the reorganisation of Irish credit institutions will be assessed by the authorities, together with the European Commission, the ECB and the IMF.

- Review progress against PCAR requirements.

\section{iii. Structural reforms}

\section{To increase growth in the domestic services sector}

Government will introduce legislative changes to remove restrictions to trade and competition in sheltered sectors including:

- the legal profession, establishing an independent regulator for the profession and implementing the recommendations of the Legal Costs Working Group and outstanding Competition Authority recommendations to reduce legal costs. 
- medical services, eliminating restrictions on the number of GPs qualifying and removing restrictions on GPs wishing to treat public patients as well as restrictions on advertising.

- the pharmacy profession, ensuring that the recent elimination of the 50\% mark-up paid for medicines under the State's Drugs Payments Scheme is enforced.

To enhance competition in open markets

- Government should introduce reforms to legislation to (1) empower judges to impose fines and other sanctions in competition cases in order to generate more credible deterrence and (2) require the competition authorities to list restrictions in competition law which exclude certain sectors from its scope and to identify processes to address those exclusions.

To encourage growth in the retail sector

- The government will conduct a study on the economic impact of eliminating the cap on the size of retail premises with a view to enhancing competition and lowering prices for consumers and discuss implementation of its policy implications with the Commission services.

\section{v. Structural fiscal reforms}

To put the public service pension system on a more sustainable basis

- Pension entitlements for new entrants to the public service will be reformed with effect from 2011. This will include a review of accelerated retirement for certain categories of public servants and an indexation of pensions to consumer prices. Pensions will be based on career average earnings. New public service entrants will also see a $10 \%$ pay reduction. New entrants' retirement age will also be linked to the state pension retirement age.

To ensure a more credible fiscal framework

- Assessment of work in progress related to the fiscal governance requirements considered in the previous quarters.

\section{To facilitate better government at a local level}

- Government will ensure that effective measures are in place to cap the contribution of the local government sector to general government borrowing at an acceptable level. The mechanisms in place to underpin this position will be kept under close review, in consultation with the Commission services. The review will also consider how to provide data on the financial position including assets and liabilities of the sector on a timelier basis. 


\section{Actions for the fourth review (actions to be completed by end Q4- 2011)}

\section{i. Fiscal consolidation}

Government will rigorously implement the budget for 2011 and the fiscal consolidation measures announced afterwards, consistent with the requirements of the excessive deficit procedure. Progress is assessed against the (cumulative) quarterly primary deficit ceilings in the Memorandum of Economic and Financial Polices (MEFP) including the Technical Memorandum of Understanding (TMU).

The government will provide a draft budget for 2012 aiming to further reduce the general government deficit in line with the National Recovery Plan and the programme and including the detailed presentation of consolidation measures amounting to at least $€ 3$.6bn.

- Revenue measures to yield $€ 1,500 \mathrm{~m}^{4}$ in a full year will be adopted, including:

- A lowering of personal income tax bands and credits.

- A reduction in private pension tax reliefs.

- A reduction in general tax expenditures.

- A property tax.

- A reform of capital gains tax and acquisitions tax.

- An increase in the carbon tax.

- The budget will provide for a reduction of expenditure in 2012 of $€ 2,100 \mathrm{~m}$ including:

- Social expenditure reductions.

- Reduction of public service numbers and public service pension adjustments.

- Other programme expenditure, and reductions in capital expenditure.

The Authorities will adopt measures to ensure that the deficit reduction targets as set out in the National Recovery Plan are achieved.

The Department of Finance will continue to ensure tight supervision of expenditure commitments by the line departments, and effective tax collection, to make certain that the primary deficit target in cash (see Table 1 of MEFP) and the general government nominal budget deficit on ESA95 basis as set out in the EU Council Recommendation on excessive deficit procedures are achieved.

\footnotetext{
${ }^{4}$ Inclusive of 2011 carryover
} 


\section{ii. Financial sector reforms}

- Progress in implementing of the strategy for the reorganisation of Irish credit institutions will be assessed by the authorities, together with the European Commission, the ECB and the IMF.

\section{iii. Structural reforms}

To assist in financing need and to increase competition

- Building on the forthcoming report of the Review Group on State Assets \& Liabilities the government will undertake an independent assessment of the electricity and gas sectors. State authorities will consult with the Commission Services on the results of this assessment with a view to setting appropriate targets.

In advance of the introduction of water charges

- The government will have undertaken an independent assessment of transfer of responsibility for water services provision from local authorities to a water utility, and prepare proposals for implementation, as appropriate with a view to start charging in 2012/2013.

\section{iv. Structural fiscal reforms}

To reinforce the credibility of the budgetary process

- Assessment of work in progress related to the fiscal governance requirements considered in the previous quarters.

- The Government will introduce a Fiscal Responsibility Law which will include provision for a medium-term expenditure framework with binding multi-annual ceilings on expenditure in each area by Q4 2011. This will take into account any revised economic governance reforms at $\mathrm{EU}$ level and will build on reforms already in place.

\section{Actions for the fifth review (actions to be completed by end Q1-2012)}

\section{i. Fiscal consolidation}

Government will rigorously implement the budget for 2012 and the fiscal consolidation measures announced afterwards, consistent with the requirements of the excessive deficit procedure. Progress is assessed against the (cumulative) quarterly primary deficit ceilings in the Memorandum of Economic and Financial Polices (MEFP) including the Technical Memorandum of Understanding (TMU). Finance Bill 2012 will contain necessary provisions to bring into effect the already signalled VAT increases in 2013 and 2014.

The Department of Finance will continue to ensure tight supervision of expenditure commitments by the line departments, and effective tax collection, to make certain that the 
primary deficit target in cash (see Table 1 of MEFP) and the general government nominal budget deficit on ESA95 basis as set out in the EU Council Recommendation on excessive deficit procedures are achieved.

\section{ii. Financial sector reforms}

- PCAR for 2012 will be completed. The methodology used will be published in detail. The Government will ensure that the banks adhere to the requisite capital ratios.

- PLAR 2012 will be completed and any related actions will be assessed, together with the European Commission, the ECB and the IMF.

- Progress in implementing of the strategy for the reorganisation of Irish credit institutions will be assessed by the authorities, together with the European Commission, the ECB and the IMF

- Legislation to reform the bankruptcy regime to be presented to the Houses of the Oireachtas.

\section{iii. Structural reforms}

To boost the integrity of the fiscal framework

- Assessment of work in progress related to the fiscal governance requirements considered in the previous quarters.

- Legislation to reform personal debt regime submitted to the Houses of the Oireachtas.

\section{Actions for the sixth review (actions to be completed by end Q2-2012)}

\section{i. Fiscal Consolidation}

The Department of Finance will continue to ensure tight supervision of expenditure commitments by the line departments, and effective tax collection, to make certain that the primary deficit target in cash (see Table lof MEFP) and the general government nominal budget deficit on ESA95 basis as set out in the EU Council Recommendation on excessive deficit procedures are achieved.

\section{ii. Financial sector reforms}

- The results of the PCAR for 2012 will be assessed, together with European Commission, the ECB and the IMF. The results will then be published in detail and on a bank-by-bank basis.

- Depending on the results of the PCAR 2012, the Government will ensure that the minimum capital requirement of $10.5 \%$ will be maintained. 
- Progress in implementation of the strategy for the restructuring of the Irish credit institutions banking system will be assessed by the authorities, together with the European Commission, the ECB and the IMF.

\section{iii. Structural fiscal reforms}

To further enhance the credibility of the fiscal framework

- Assessment of work in progress related to the fiscal governance requirements considered in the previous quarters.

\section{Actions for the seventh review (actions to be completed by end Q3- 2012)}

\section{i. Fiscal Consolidation}

The Department of Finance will continue to ensure tight supervision of expenditure commitments by the line departments, and effective tax collection, to make certain that the primary deficit target in cash (see Table 1 of MEFP) and the general government nominal budget deficit on ESA95 basis as set out in the EU Council Recommendation on excessive deficit procedures are achieved.

\section{ii. Financial sector reforms}

- Interim review of progress under PLAR 2011 and any related actions will be assessed, together with the European Commission, the ECB and the IMF.

- Progress in implementing of the strategy for restructuring of the Irish credit institutions will be assessed by the authorities, together with the European Commission, the ECB and the IMF.

- Review progress against PCAR requirements.

\section{Actions for the eighth review (actions to be completed by end Q4-2012)}

\section{i. Fiscal consolidation}

The government will provide a draft budget for 2013 aiming at a further reduction of the general government deficit in line with the 4-year plan and the programme and including the detailed presentation of consolidation measures amounting to at least $€ 3,100 \mathrm{~m}$.

- Revenue measures to raise at least $€ 1,100 \mathrm{~m}^{5}$ in the full year will be introduced, including:

- A lowering of personal income tax bands and credits.

\footnotetext{
${ }^{5}$ Inclusive of carryover from 2012
} 
- A reduction in private pension tax relief.

- A reduction in general tax expenditures.

- An increase in property tax.

- The budget will provide for a reduction in expenditure in 2013 of no less than $€ 2,000 \mathrm{~m}$, including:

- Social expenditure reductions.

- Reduction of public service numbers and public service pension adjustments.

- Other programme expenditure, and reductions in capital expenditure.

The Department of Finance will continue to ensure tight supervision of expenditure commitments by the line departments, and effective tax collection, to make certain that the primary deficit target in cash (see Table 1 of MEFP) and the general government nominal budget deficit on ESA95 basis as set out in the EU Council Recommendation on excessive deficit procedures are achieved.

\section{ii. Financial sector reforms}

- Progress in implementation of the strategy for the reorganisation of Irish credit institutions will be assessed by the authorities, together with the European Commission, the ECB and the IMF.

- Implementing of the plan for restructuring and strengthening the balance sheets of the credit union sector will be completed.

- Legislation to reform the bankruptcy regime to be presented to the Houses of the Oireachtas.

\section{Actions for the ninth review (actions to be completed by end Q1-2013)}

\section{i. Fiscal consolidation}

Government will rigorously implement the budget for 2013 and the fiscal consolidation measures announced afterwards, consistent with the requirements of the excessive deficit procedure. Progress is assessed against the (cumulative) quarterly primary deficit ceilings in the Memorandum of Economic and Financial Polices (MEFP) including the Technical Memorandum of Understanding (TMU).

The Department of Finance will continue to ensure tight supervision of expenditure commitments by the line departments, and effective tax collection, to make certain that the primary deficit target in cash (see Table 1 of MEFP) and the general government nominal budget deficit on ESA95 basis as set out in the EU Council Recommendation on excessive deficit procedures are achieved. 


\section{ii. Financial sector reforms}

- PCAR for 2013 will be completed. The methodology used will be published in detail.

- PLAR 2012 will be completed and any related actions will be assessed, together with the European Commission, the ECB and the IMF.

- Progress in implementing of the strategy for the reorganisation of Irish credit institutions will be assessed by the authorities, together with the European Commission, the ECB and the IMF.

\section{iii. Structural fiscal reforms}

- Assessment of work in progress related to the fiscal reforms considered in the previous quarters.

- The nominal value of the State pension should not rise over the period of the programme.

\section{Actions for the tenth review (actions to be completed by end Q2-2013)}

\section{i. Fiscal Consolidation}

The Department of Finance will continue to ensure tight supervision of expenditure commitments by the line departments, and effective tax collection, to make certain that the primary deficit target in cash (see Table 1 of MEFP) and the general government nominal budget deficit on ESA95 basis as set out in the EU Council Recommendation on excessive deficit procedures are achieved.

\section{ii. Financial sector reforms}

- The results of the PCAR for 2013 will be assessed, together the European Commission, the ECB and the IMF. The results will then be published in detail and on a bank-by-bank basis.

- Depending on the results of the PCAR 2013, the Government will ensure that the minimum capital requirement of $10.5 \%$ will be maintained.

- The PLAR for 2013 will be completed.

- Progress in implementation of the strategy for the restructuring the banking system will be assessed by the authorities, together with the European Commission, the ECB and the IMF. 


\section{Actions for the eleventh review (actions to be completed by end Q3- 2013)}

\section{i. Fiscal Consolidation}

The Department of Finance will continue to ensure tight supervision of expenditure commitments by the line departments, and effective tax collection, to make certain that the primary deficit target in cash (see Table 1of MEFP) and the general government nominal budget deficit on ESA95 basis as set out in the EU Council Recommendation on excessive deficit procedures are achieved.

\section{ii. Financial sector reforms}

- Interim review of progress under PLAR 2011 and any related actions will be assessed, together with the European Commission, the ECB and the IMF.

- Progress in implementing of the strategy for the reorganisation of Irish credit institutions will be assessed by the authorities, together with the European Commission, the ECB and the IMF.

- Review progress against PCAR requirements

\section{Actions for the twelfth review (actions to be completed by end Q4- 2013)}

\section{i. Fiscal Consolidation}

The Department of Finance will continue to ensure tight supervision of expenditure commitments by the line departments, and effective tax collection, to make certain that the primary deficit target in cash (see Table 1 of MEFP) and the general government nominal budget deficit on ESA95 basis as set out in the EU Council Recommendation on excessive deficit procedures are achieved.

\section{ii. Financial sector reforms}

- Progress in implementing of the strategy for the reorganisation of Irish credit institutions will be assessed by the authorities, together with the European Commission, the ECB and the IMF. 


\section{Annex 1. Provision of data}

During the programme, the following indicators and reports shall be made available to the European Commission, the ECB and the IMF staffs by the authorities on a regular basis.

\section{To be provided by the Department of Finance}

Monthly data on adherence to budget targets (Exchequer statement, details on Exchequer revenues and expenditure with information on Social Insurance Fund to follow as soon as practicable).

Updated monthly report on the central government's budget execution and prospects for the remainder of the year.

Quarterly data on main revenue and expenditure items of local government.

Updated annual plans for the general government balance showing transition from the Exchequer balance to the general government balance (using presentation in Table 1 and Table 2A of the EDP notification).

Quarterly data on the public service wage bill, number of employees and average wage (using the presentation of the Pay and Pension Bill with further details on pay and pension costs of local authorities).

Information on the main Government spending and receipt items

Quarterly data on general government accounts, and general government debt as per the relevant EU regulations on statistics.

Updated annual plans of the general government balance and its breakdown into revenue and expenditure components for the current year and the following four years, using presentation in the stability programme's standard table on general government budgetary prospects.

\section{To be provided by the NTMA}

Weekly information on the Government's cash position with indication of sources as well of number of days covered

Data on below-the-line financing for the general government.

Data on public debt, new guarantees and other instruments issued by the general government to public enterprises, banks and the private sector.

Data on short-, medium- and long-term debt falling due (all instruments) over the next 36 months for the general government (interest and amortisation) and for central government and local authorities

Data on short-, medium- and long-term debt falling due (all instruments) over the next 36 months for State-guaranteed enterprises (interest and amortisation) (or Dept of Finance)

Updated estimates of financial sources (bonds issuance, other financing sources) for the banking and government sectors in the next 12 months
Monthly, 10 days after the end of each month

Monthly, 30 days after the end of each month

Quarterly, 90 days after the end of each quarter

Monthly, 30 days after the end of each month

Quarterly, 30 days after the end of each quarter

Weekly on Friday, reporting on the previous Thursday

Quarterly accrual data, 90 days after the end of each quarter

Together with EDP notification

Weekly on Friday, reporting on the previous Thursday

Monthly, no later than 15 days after the end of each month

Monthly, 30 days after the end of each month

Monthly, 30 days after the end of each month

Quarterly, 30 days after the end of each quarter

Monthly, 30 days after the end of each month 


\section{To be provided by the Central Bank}

Assets and liabilities of the Central Bank

Assets and liabilities of the Irish banking system - aggregate monetary balance sheet of credit institutions

Short-, medium- and long-term debt falling due (by type of instrument) over the next 36 months for domestic banks of systemic importance (interest and amortisation).

Weekly individual operational balance sheets of commercial banks (of systemic importance), including detailed information on deposits (by maturity and type of depositor) and loans provided to the public and the private sector (households and corporates)

Public debt and new guarantees issued by the general government to banks.

Financial stability indicators (IMF core set: deposits, non-performing loans, capital adequacy ratios)) for systemic domestic banks

Estimates of domestic banks' capital needs in the next 12 months

Estimates of funding sources for the banking sector for the next 12 months
Weekly, next working day

Monthly, 30 days after the end of each month

Monthly, 30 days after the end of each month

Weekly, next working day

Monthly, 30 days after the end of each month

Monthly, 30 days after the end of each month

Monthly, 30 days after the end of each month

Monthly, 30 days after the end of each month 


\section{INTERNATIONAL MONETARY FUND}

\section{Ireland-Assessment of the Risks to the Fund and the Fund's Liquidity Position}

Prepared by the Finance and Strategy, Policy, and Review Departments

(In consultation with other Departments)

Approved by Andrew Tweedie and Martin Mühleisen

December 8, 2010

1. This note assesses the risks to the Fund arising from the proposed arrangement under the Extended Fund Facility (EFF) for Ireland and its effects on the Fund's liquidity, in accordance with the policy on exceptional access. ${ }^{1}$ The authorities are requesting a three-year extended arrangement with access of SDR 19.5 billion (2,322 percent of quota or 564 percent of proposed $14^{\text {th }}$ General Review quota). The arrangement would have a frontloaded purchase schedule with a first purchase of SDR 5 billion (598 percent of quota) upon approval, followed by twelve purchases as shown in Table 1. Access during the first year would reach almost 1,500 percent of quota and the last purchase under the arrangement would be available in November 2013. Ireland has not had any arrangements with the Fund.

Table 1. Ireland: Proposed EFF-Access and Phasing

\begin{tabular}{clrrr}
\hline \multirow{2}{*}{ Availability } & & \multicolumn{2}{c}{ Percent of quota } \\
\cline { 4 - 5 } 2010 & Date 1/ & SDR mn & Purchase & Cumulative \\
\hline \multirow{2}{*}{2011} & March & $5,012.4$ & 597.9 & 597.9 \\
& June & $1,839.1$ & 219.4 & 817.2 \\
& September & $1,839.1$ & 219.4 & $1,036.6$ \\
& December & $1,839.1$ & 219.4 & $1,255.9$ \\
& March & $1,839.1$ & 219.4 & $1,475.3$ \\
& June & $1,417.2$ & 169.0 & $1,644.3$ \\
& September & $1,417.2$ & 169.0 & $1,813.4$ \\
& December & $1,417.2$ & 169.0 & $1,982.4$ \\
& March & $1,417.2$ & 169.0 & $2,151.4$ \\
& June & 357.0 & 42.6 & $2,194.0$ \\
& September & 357.0 & 42.6 & $2,236.6$ \\
& November & 357.0 & 42.6 & $2,279.2$ \\
& Total & 357.0 & 42.6 & $2,321.8$ \\
& Total) & $19,465.8$ & $2,321.8$ & $2,321.8$ \\
\hline
\end{tabular}

Source: Finance Department.

1/ Starting March 2011 purchases will be condition on the completion of a review.

\footnotetext{
${ }^{1}$ Decision No. 14064-(08/18), February 22, 2008, as amended by Decision No. 14184-(08/93), October 29, 2008, and Decision No. 14284-(09/29), March 24, 2009.
} 


\section{BACKGROUND}

\section{Ireland's external debt is the highest of recent exceptional access cases, with} private sector debt accounting for the largest share. Ireland's total external debt is projected at over 1000 percent of GDP at end-2010 (Table 2 and Figure 1). While a substantial portion of gross debt is accounted for by the liabilities of International Financial Sector Center (IFSC) participants, which do not reflect Irish risk, excluding an estimate of the bank component of this IFSC debt would still leave total external debt at almost 800 percent of GDP, with banks' external liabilities accounting for about half. ${ }^{2}$ Ireland's total external and private external debts as ratios of GDP are the highest among recent exceptional access cases (Figure 2, Panels A and B). ${ }^{3}$ At end-2010, Ireland's total stock of private shortterm external debt is projected at approximately 370 percent of GDP, of which about a fifth consists of banks' repos with the ECB.

Table 2. Ireland: Total External Debt, 2005-2009 1/

\begin{tabular}{|c|c|c|c|c|c|c|}
\hline & 2005 & 2006 & 2007 & 2008 & 2009 & $20102 /$ \\
\hline \multicolumn{7}{|c|}{ (bn of euros) } \\
\hline Total External Debt & 1,133 & 1,339 & 1,540 & 1,693 & 1,655 & 1,699 \\
\hline Public & 32 & 30 & 31 & 102 & 129 & 196 \\
\hline Short-term & 5 & 3 & 1 & 63 & 69 & 115 \\
\hline Long-term & 27 & 27 & 29 & 39 & 60 & 81 \\
\hline Private & 1,101 & 1,309 & 1,509 & 1,590 & 1,527 & 1,503 \\
\hline Short-term & 503 & 555 & 614 & 677 & 598 & 580 \\
\hline Long-term & 598 & 754 & 896 & 913 & 929 & 922 \\
\hline \multicolumn{7}{|c|}{ (percent of GDP) } \\
\hline Total External Debt & 698 & 755 & 813 & 940 & 1,037 & 1,085 \\
\hline Public & 19 & 17 & 16 & 57 & 81 & 125 \\
\hline Short-term & 3 & 1 & 1 & 35 & 43 & 73 \\
\hline Long-term & 17 & 15 & 16 & 22 & 37 & 52 \\
\hline Private & 678 & 738 & 797 & 884 & 956 & 959 \\
\hline Short-term & 310 & 313 & 324 & 376 & 375 & 370 \\
\hline Long-term & 368 & 425 & 473 & 507 & 582 & 589 \\
\hline \multicolumn{7}{|l|}{ Memorandum items (percent of GDP): } \\
\hline Total External Debt, net of IFSC bank liabilities 3/ & 609 & 624 & 578 & 623 & 690 & 798 \\
\hline Short-term external debt & 313 & 314 & 325 & 411 & 418 & 444 \\
\hline Total public sector debt & 27 & 25 & 25 & 44 & 66 & 99 \\
\hline
\end{tabular}

Source: Irish Authorities, BIS, and IMF staff estimates.

$1 /$ End of year unless otherwise indicated.

2/ Staff projections for end-2010.

3/ International financial services center (IFSC) participants locate in Ireland and perform wholesale and back-office services for off-shore clients and parent companies, but are not part of the domestic

banking system. The difference between BIS locational and consoldiated, ultimate risk basis foreign liabilities of Irish banks reflects the liabilities of the banking IFSC sector and is used to adjust gross external debt downward. This adjustment does not cover non-bank IFSC financial entities.

\footnotetext{
${ }^{2}$ This estimate reflects consolidated bank data published by the BIS. Non-bank IFSC financial entities, which are not covered by BIS reporting, may further reduce total external debt. Private external debt related to foreign direct investment consists of about 15 percent of GDP. As reported in Ireland-Request for an Extended Arrangement, Correction 1, (page 44), when holdings of foreign assets are taken into consideration, the Irish external position is a net liability of circa 90 percent of GDP.

${ }^{3}$ Throughout the paper recent exceptional access cases refer to arrangements since September 2008.
} 
Figure 1. Distribution of Cross-Border Exposure 1/ (as a percentage of total cross-border exposure)

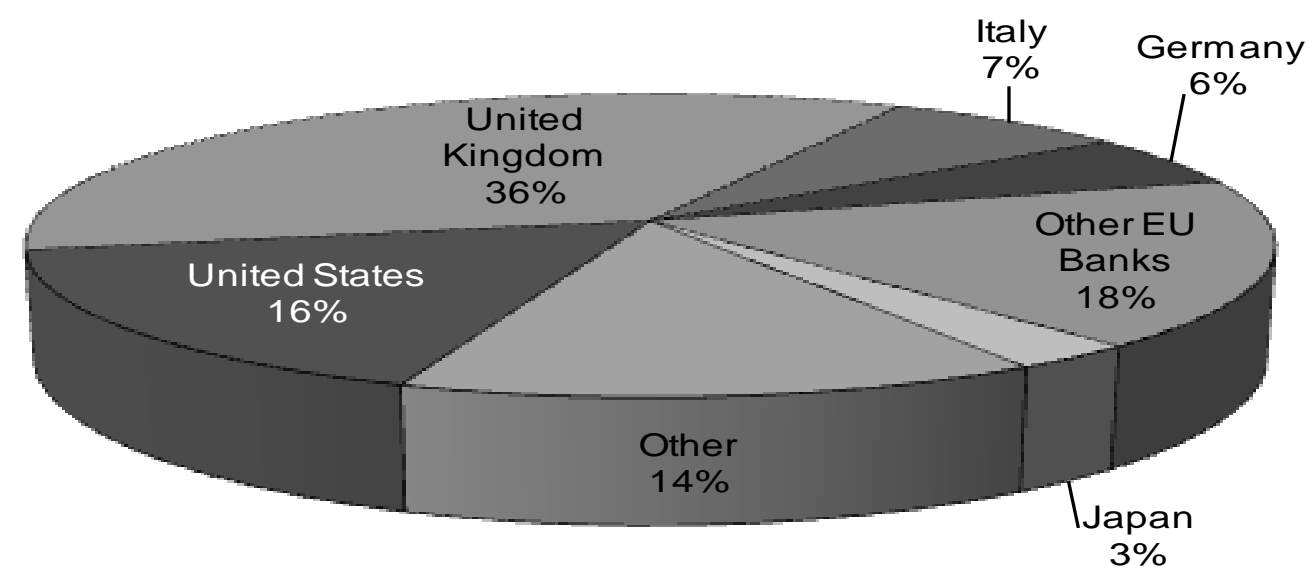

Total exposure of EU banks (66\% of total )

1/BIS con solidated cross border liabilites, ultimate risk bas is.

3. Ireland's external debt service burden is heavy. Reflecting the country's high debt stock, Ireland's external debt service is higher than that for most of the other exceptional access cases (Figure 2, Panel C). ${ }^{4}$

4. Public debt and public external debt are high. Total general government debt is projected at around 100 percent of GDP at end-2010 - one of the highest ratios among recent exceptional access cases (Figure 2, Panel D). It has exploded from 25 percent of GDP in 2007 (Table 2) owing to large fiscal deficits including bank recapitalization costs. ${ }^{5}$ In 2010, external public sector debt is projected at 125 percent of GDP, the highest among recent exceptional access cases (Figure 2, Panel B) up from about 16 percent in 2007.

\footnotetext{
${ }^{4}$ If amortization of short-term debt (90 percent of total amortization in 2010) were included, Ireland's total external debt service would rise from about 80 percent to 473 percent in terms of exports of goods and services.

${ }^{5}$ Total general government debt, as defined by Eurostat, does not include external liabilities of the Central Bank of Ireland (about 34 percent of GDP at end-2009), which, however, are included in total external public sector debt.
} 
Figure 2. Debt Ratios for Recent Exceptional Access Arrangements 1/

A. Total External Debt 2/

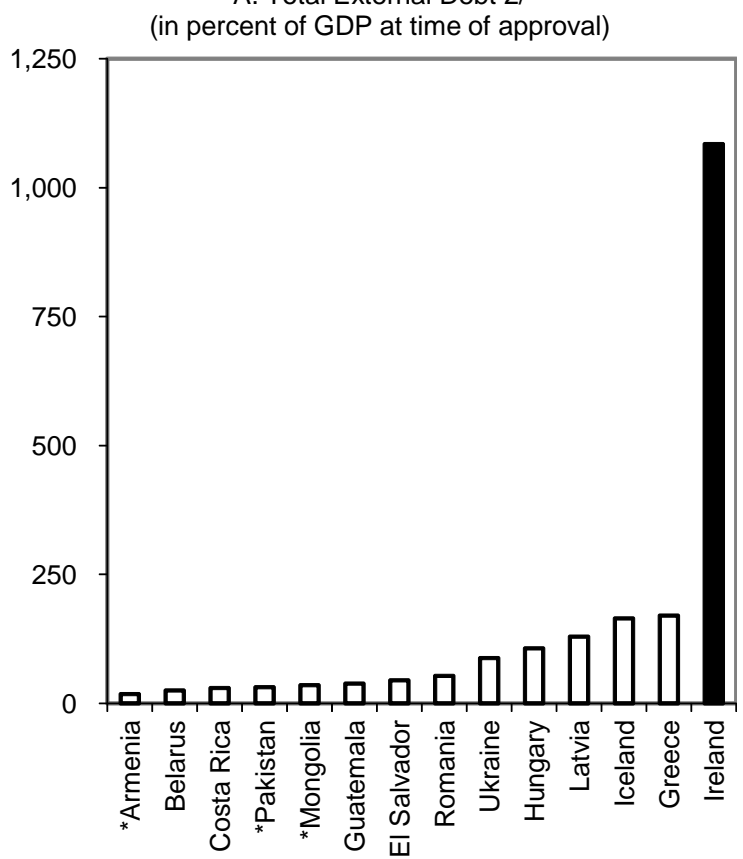

C. External Debt Service to Exports of Goods and Services (in percent)

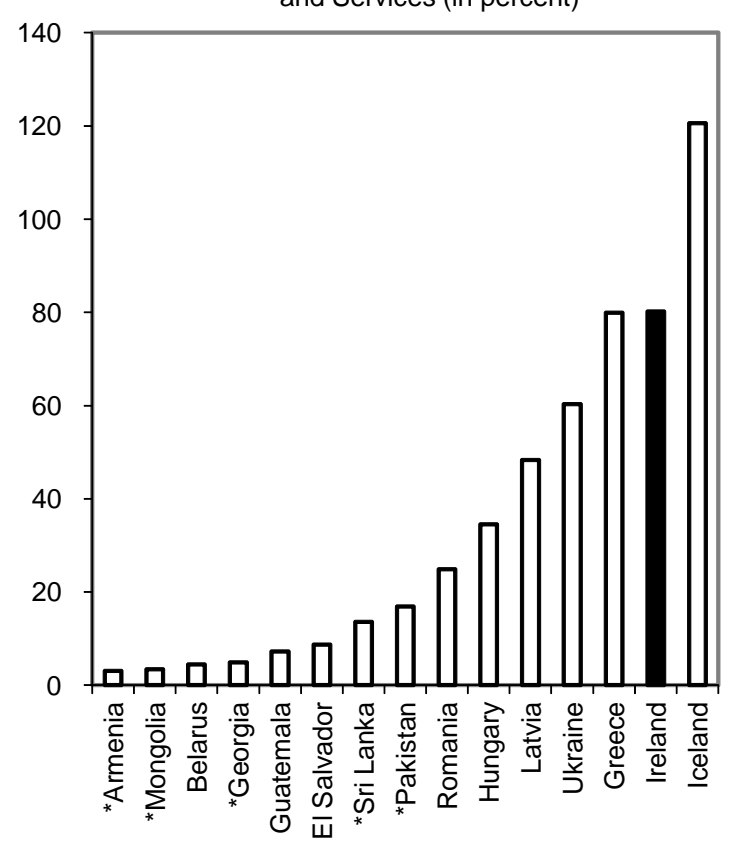

B. Public External Debt (in percent of GDP at time of approval)

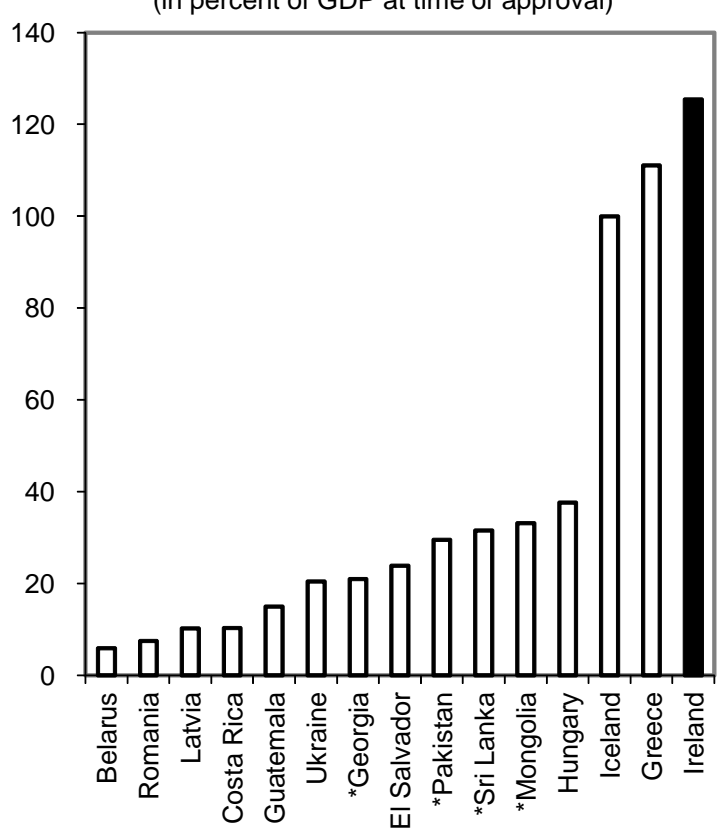

D. Total Public Debt (in percent of GDP at time of approval)

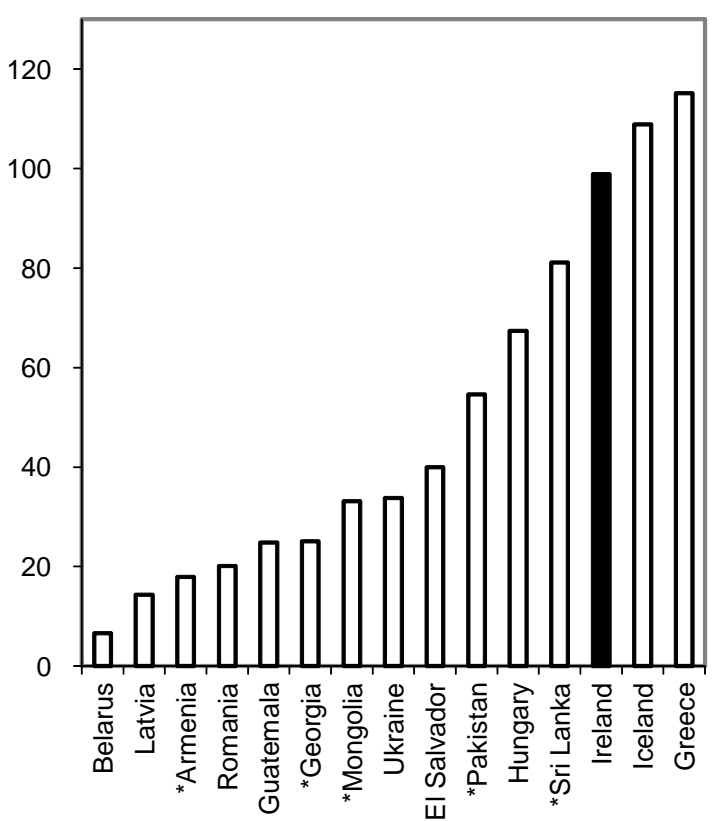

Source: Irish Authorities and IMF staff estimates, and World Economic Outlook.

1/ For arrangements approved since September 2008, estimates as reported in each staff report on the request of the Stand-By Arrangement or Extended Fund Facility. For Ireland, ratios reflect projected end-2010 data. Asterisks indicate PRGT eligible countries.

2/ Adjusting for IFSC external liabilities as in table 2 footnote 3, Irish total external debt would be reduced to approximately 798 percent of GDP.

3 / Amortization of medium and long-term external debt and total interest payments. 


\section{The EXTENDED ARRANGEMENT-RISKS AND IMPACT ON FUND's FinANCES}

\section{A. Risks to the Fund}

\section{Financing under the proposed EFF would surpass the access limits and be among the highest in terms of the level, and especially the duration, of access:}

- If all purchases were to be made as scheduled, Ireland's outstanding use of GRA resources would rise from almost 600 percent of quota (145 percent of proposed $14^{\text {th }}$ General Review quota) upon approval to about 1,500 percent of quota (about 360 percent of proposed $14^{\text {th }}$ General Review quota) during the first year of the arrangement, peaking at just over 2,300 percent of quota (just over 560 percent of proposed $14^{\text {th }}$ General Review quota) in November 2013. ${ }^{6}$ In terms of quota, this projected peak exposure would be among the highest in Fund history, and exposure could remain at a high level notably longer than in other exceptional access cases given the repurchase schedule of the EFF (Figure 3). ${ }^{7}$

Figure 3. Fund Credit Outstanding in the GRA around Peak Borrowing 1/ (In percent of quota)

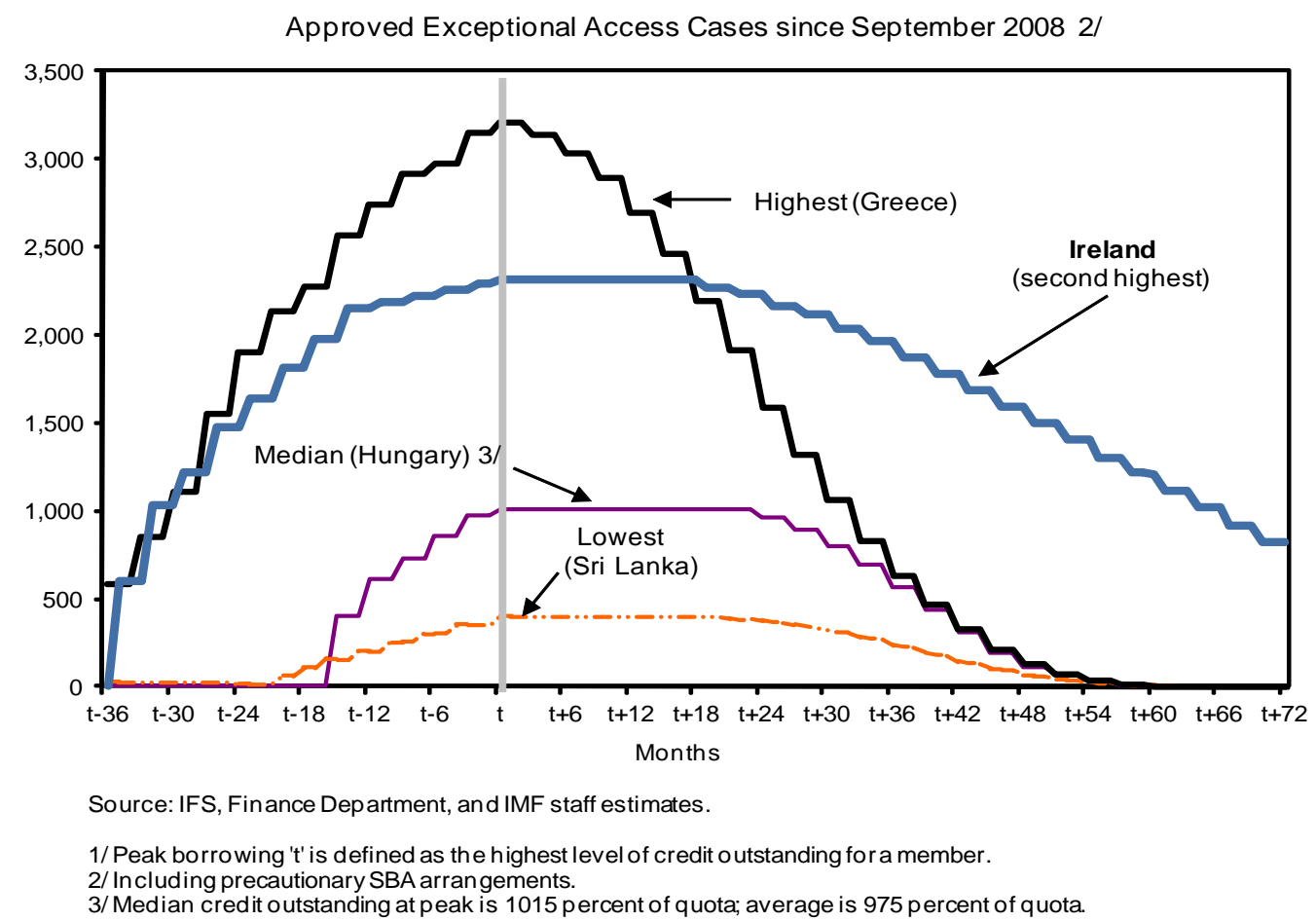

\footnotetext{
${ }^{6}$ Proposed $14^{\text {th }}$ General Review quota is SDR 3449.9 million compared to actual quota of SDR 838.4 million.

${ }^{7}$ The previous arrangements with the highest approved access as percentage of quota were Greece (3,212 percent) in 2010, Korea (1,938 percent) in 1997, and Turkey (1,560 percent) in 2001.
} 
- If all purchases under the proposed EFF are made, GRA credit outstanding to Ireland would peak at over 13 percent of GDP and over 10 percent of total external public debt by 2013 (Table 3). The peak ratio in terms of GDP would be among the highest of recent exceptional access cases, below Iceland and Ukraine (Figure 4, Panel A). ${ }^{8}$

- In terms of SDRs, the projected peak GRA exposure of SDR 19.5 billion would be second highest among recent exceptional access cases (Figure 5, Panel A). ${ }^{9}$

6. If all purchases under the proposed extended arrangement take place as scheduled, debt service ratios to the Fund would be moderate in terms of a range of standard indicators, although in the context of a heavy overall external debt service burden. ${ }^{10}$ Ireland's projected debt service to the Fund would peak at over SDR 3.7 billion in 2018 (Table 3), equivalent to about 2.1 percent of GDP and about 5.6 percent of general government revenues. While debt service to the Fund would peak at a modest 1.9 percent of exports of goods and services (Figure 4, Panel D), this is in the context of a high overall external debt service burden approaching 80 percent of exports of goods and services at its peak (Figure 4, Panel B).

\footnotetext{
${ }^{8}$ GRA credit outstanding to Ireland would peak at 110 percent of gross international reserves in 2013 (Figure 4, Panel C), but this indicator is less relevant in the case of Ireland owing to its Euro-area membership.

${ }^{9}$ This assumes that no drawings are made under existing FCL arrangements.

${ }^{10}$ Debt service to the Fund is calculated assuming that all repurchases are made as scheduled, i.e., each purchase is repurchased in twelve semi-annual installments, beginning in $4 \frac{1}{2}$ years after each purchase and ending after 10 years. Level and time-based surcharges of up to 300 basis points above the basic rate of charge apply to outstanding credit above 300 percent of quota (Decision No. 1234-(00/117), November 28, 2000, as amended by decision No. 14285-(09/29), March 24, 2009).
} 
Figure 4. Peak Fund Exposure and Debt Service Ratios for Recent Exceptional Access Cases

\section{Peak Fund Exposure Ratios}

A. In Percent of GDP

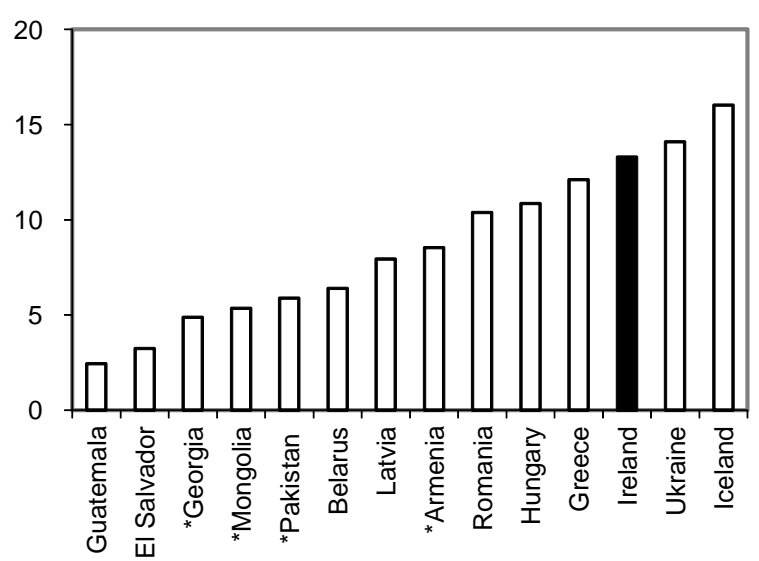

C. In Percent of Gross International Reserves

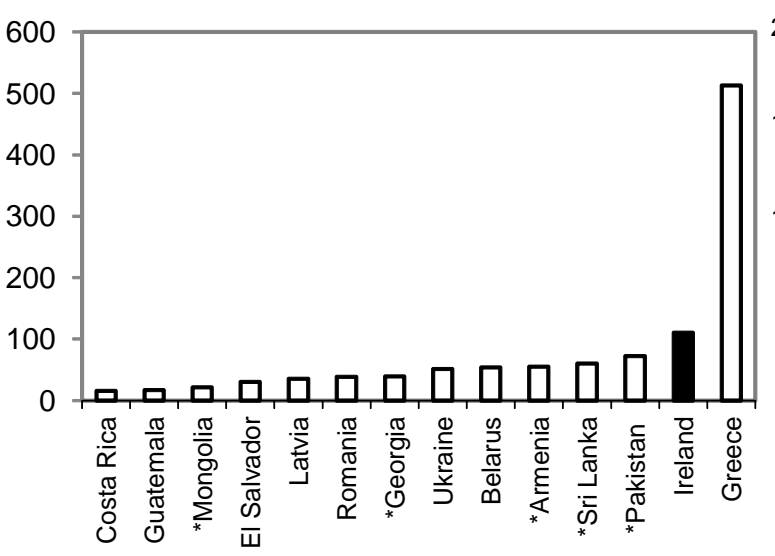

E. In Percent of Total External Debt

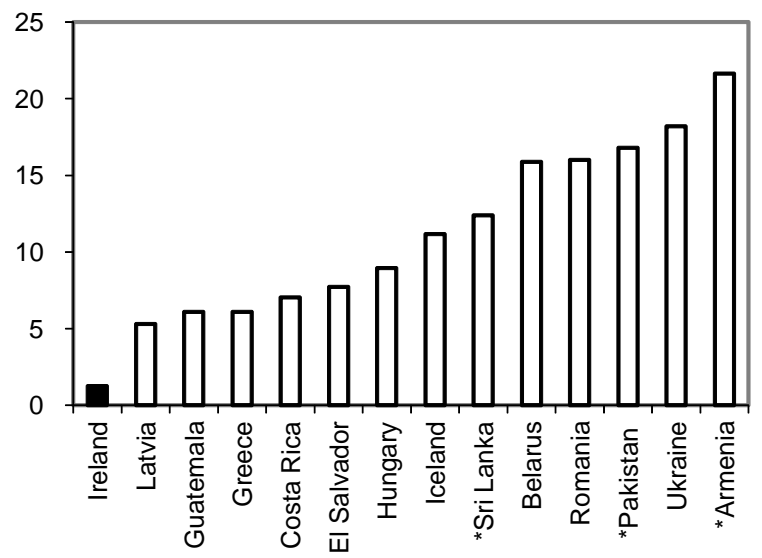

Peak Debt Service Ratios

B. Total External Debt Service in Percent of Exports of Goods and Services 1/

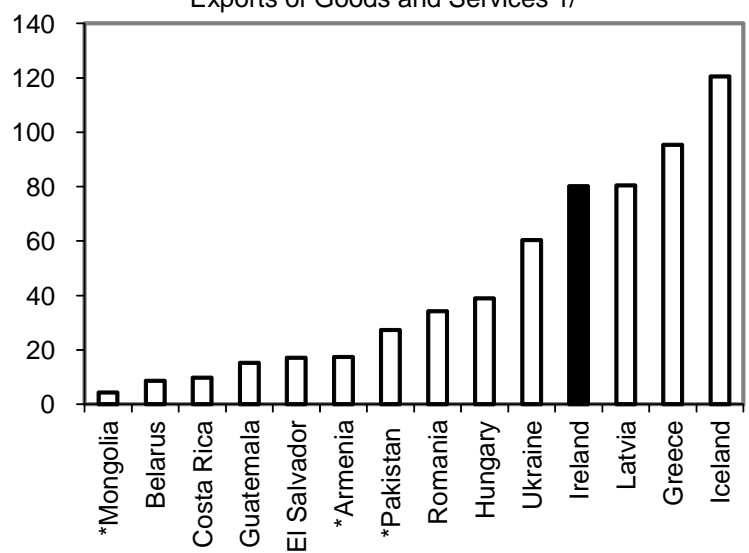

D. Debt Service to the Fund in Percent of Exports of Goods and Services

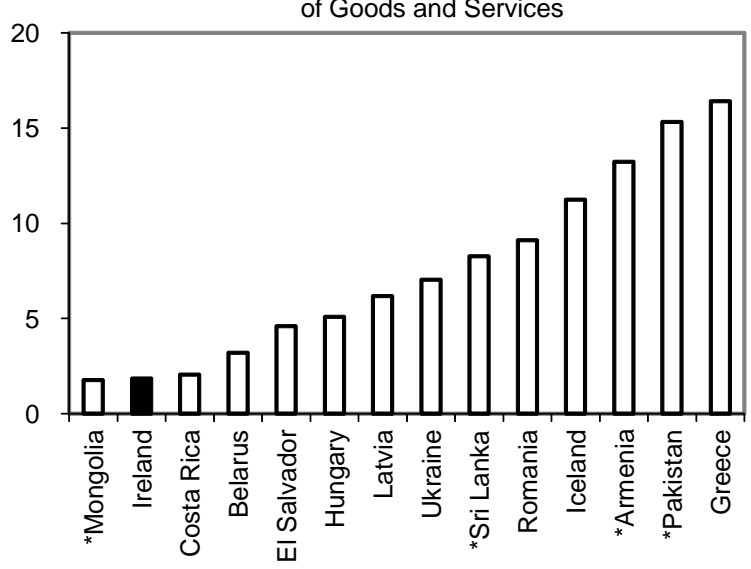

F. Debt Service to the Fund in Percent of Total External Debt Service

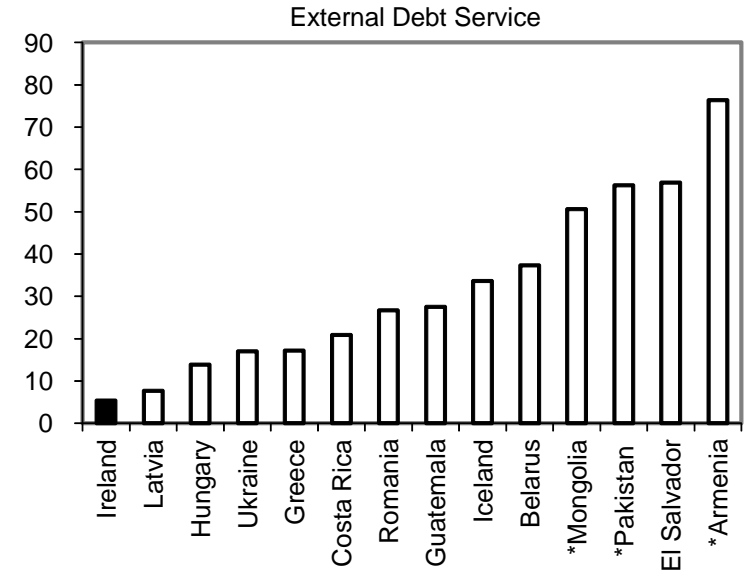

Source: Irish authorities and IMF staff estimates, and World Economic Outlook. Asterisks indicate PRGT eligible countries.

1/ Amortization of medium and long-term external debt and total interest payments. 
Figure 5. Exceptional Access Levels and Credit Concentration

A. Total Access of Current Exceptional Access Arrangements 1/ (In billions of SDRs)

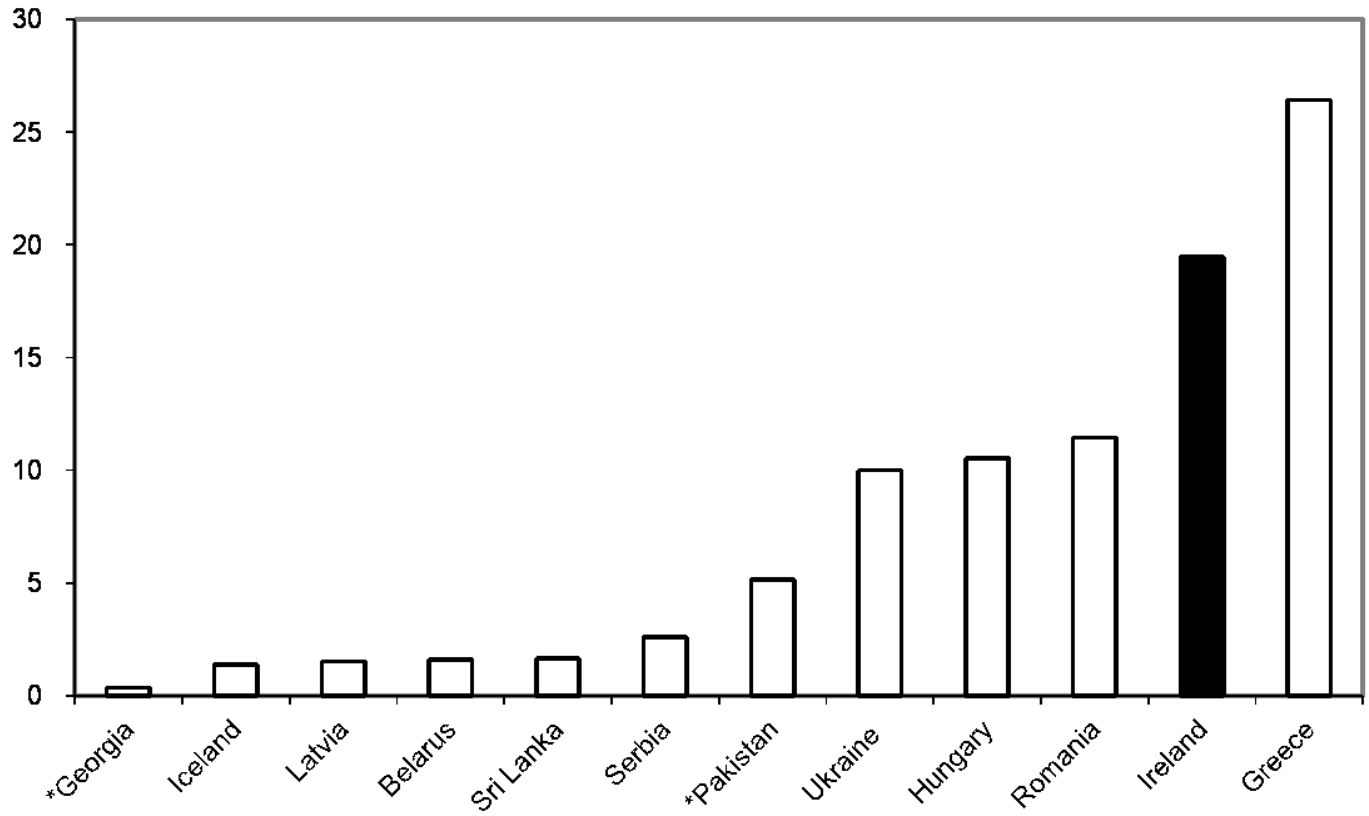

B. Credit Concentration of Fund GRA Exposure 2/ (As a percentage of total credit outstanding)

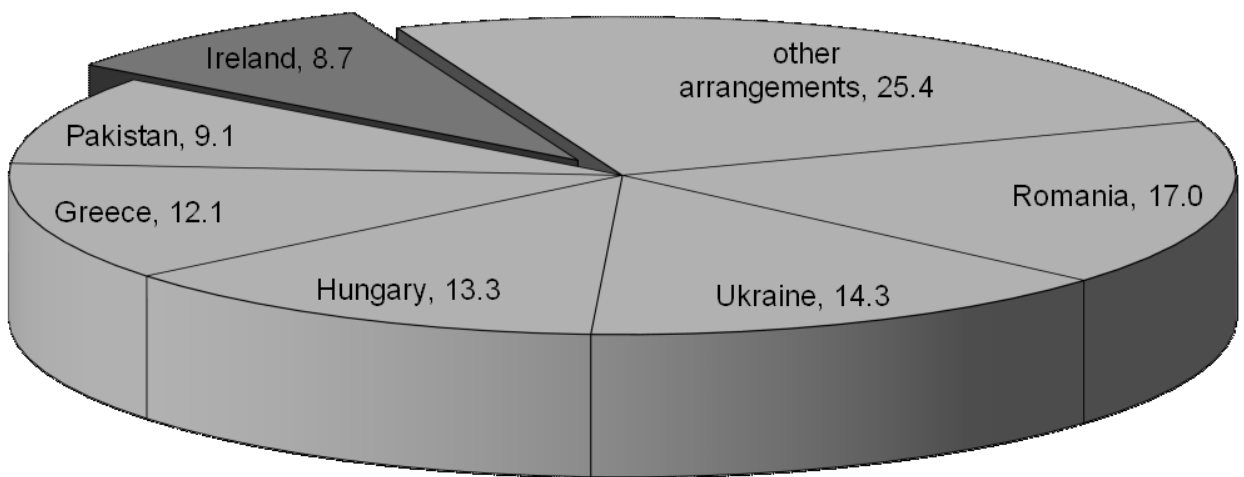

Source: Finance Department.

1/ Does not include FCL arrangements. Asterisks indicate PRGF eligible countries. $2 /$ Credit outstanding as of Nov ember 12, 2010 plus expected first purchase under the proposed arrangement with Ireland. 
Table 3. Ireland-Capacity to Repay Indicators 1/

\begin{tabular}{|c|c|c|c|c|c|c|c|c|c|c|c|c|c|}
\hline & 2010 & 2011 & 2012 & 2013 & 2014 & 2015 & 2016 & 2017 & 2018 & 2019 & 2020 & 2021 & 2022 \\
\hline \multicolumn{14}{|c|}{ Exposure and Repayments (In SDR millions) } \\
\hline $\begin{array}{l}\text { GRA credit to Ireland 2/ } \\
\text { (In percent of quota) } \\
\text { Charges due on GRA credit 3/ } \\
\text { Debt service due on GRA credit 4/ }\end{array}$ & $\begin{array}{r}5,012 \\
598 \\
25 \\
25\end{array}$ & $\begin{array}{r}12,369 \\
1,475 \\
214 \\
214\end{array}$ & $\begin{array}{r}18,038 \\
2,151 \\
443 \\
443\end{array}$ & $\begin{array}{r}19,466 \\
2,322 \\
574 \\
574\end{array}$ & $\begin{array}{r}19,466 \\
2,322 \\
758 \\
758\end{array}$ & $\begin{array}{r}18,324 \\
2,186 \\
769 \\
1,911\end{array}$ & $\begin{array}{r}16,026 \\
1,912 \\
707 \\
3,005\end{array}$ & $\begin{array}{r}12,960 \\
1,546 \\
596 \\
3,662\end{array}$ & $\begin{array}{r}9,716 \\
1,159 \\
460 \\
3,704\end{array}$ & $\begin{array}{r}6,472 \\
772 \\
318 \\
3,562\end{array}$ & $\begin{array}{r}3,227 \\
385 \\
176 \\
3,420\end{array}$ & $\begin{array}{r}1,125 \\
134 \\
49 \\
2,152\end{array}$ & $\begin{array}{r}179 \\
21 \\
12 \\
959\end{array}$ \\
\hline \multicolumn{14}{|l|}{ Debt and Debt Service Ratios 5/ } \\
\hline $\begin{array}{l}\text { In percent of GDP } \\
\text { Total external debt } \\
\text { External debt, public } \\
\text { GRA credit to Ireland } \\
\text { Total external debt service 6/ } \\
\text { Public external debt service 6/ } \\
\text { Debt service due on GRA credit 4/ }\end{array}$ & $\begin{array}{r}1,085 \\
125 \\
3.7 \\
78.8 \\
13.5 \\
0.0\end{array}$ & $\begin{array}{r}1,096 \\
139 \\
9.0 \\
77.6 \\
20.1 \\
0.2\end{array}$ & $\begin{array}{r}1,087 \\
149 \\
12.8 \\
71.0 \\
18.8 \\
0.3\end{array}$ & $\begin{array}{r}1,059 \\
154 \\
13.3 \\
64.4 \\
17.9 \\
0.4\end{array}$ & $\begin{array}{r}1,016 \\
153 \\
12.7 \\
59.4 \\
15.5 \\
0.5\end{array}$ & $\begin{array}{r}972 \\
151 \\
11.4 \\
45.9 \\
9.4 \\
1.2\end{array}$ & $\begin{array}{r}928 \\
141 \\
9.5 \\
41.4 \\
12.0 \\
1.8\end{array}$ & $\begin{array}{r}887 \\
131 \\
7.3 \\
40.4 \\
12.8 \\
2.1\end{array}$ & $\begin{array}{r}847 \\
121 \\
5.2 \\
36.9 \\
11.7 \\
2.0\end{array}$ & $\begin{array}{r}808 \\
110 \\
3.3 \\
34.8 \\
11.0 \\
1.8\end{array}$ & $\begin{array}{r}771 \\
100 \\
1.6 \\
32.6 \\
9.9 \\
1.7\end{array}$ & $\begin{array}{r}736 \\
89 \\
0.5 \\
27.7 \\
7.6 \\
1.0\end{array}$ & $\begin{array}{r}702 \\
79 \\
0.1 \\
24.6 \\
5.3 \\
0.4\end{array}$ \\
\hline $\begin{array}{l}\text { In percent of General Government Rev } \\
\text { Public external debt service 6/ } \\
\text { Debt service due on GRA credit 4/ }\end{array}$ & $\begin{array}{l}39 \\
0.1\end{array}$ & $\begin{array}{l}57 \\
0.4\end{array}$ & $\begin{array}{l}52 \\
0.9\end{array}$ & $\begin{array}{r}49 \\
1.1\end{array}$ & $\begin{array}{r}42 \\
1.3\end{array}$ & $\begin{array}{r}25 \\
3.2\end{array}$ & $\begin{array}{r}32 \\
4.8\end{array}$ & $\begin{array}{r}35 \\
5.6\end{array}$ & $\begin{array}{r}31 \\
5.4\end{array}$ & $\begin{array}{r}30 \\
4.9\end{array}$ & $\begin{array}{r}27 \\
4.5\end{array}$ & $\begin{array}{r}21 \\
2.7\end{array}$ & $\begin{array}{r}14 \\
1.1\end{array}$ \\
\hline $\begin{array}{l}\text { In percent of Gross International Reser } \\
\text { Total external debt } \\
\text { External debt, public } \\
\text { GRA credit to Ireland } \\
\text { Debt service due on GRA credit 4/ }\end{array}$ & $\begin{array}{r}81,061 \\
9,373 \\
276.3 \\
1.4\end{array}$ & $\begin{array}{r}16,265 \\
2,063 \\
133.6 \\
2.3\end{array}$ & $\begin{array}{r}8,769 \\
1,204 \\
103.2 \\
2.5\end{array}$ & $\begin{array}{r}8,787 \\
1,278 \\
110.3 \\
3.3\end{array}$ & $\begin{array}{r}9,052 \\
1,360 \\
113.1 \\
4.4\end{array}$ & $\begin{array}{r}9,459 \\
1,469 \\
110.8 \\
11.6\end{array}$ & $\begin{array}{r}9,490 \\
1,442 \\
96.9 \\
18.2\end{array}$ & $\begin{array}{r}9,520 \\
1,409 \\
78.4 \\
22.1\end{array}$ & $\begin{array}{r}9,542 \\
1,362 \\
58.7 \\
22.4\end{array}$ & $\begin{array}{r}9,564 \\
1,307 \\
39.1 \\
21.5\end{array}$ & $\begin{array}{r}9,580 \\
1,240 \\
19.5 \\
20.7\end{array}$ & $\begin{array}{r}9,596 \\
1,164 \\
6.8 \\
13.0\end{array}$ & $\begin{array}{r}9,608 \\
1,077 \\
1.1 \\
5.8\end{array}$ \\
\hline $\begin{array}{l}\text { In percent of Exports of Goods and Se } \\
\text { Total external debt service 6/ } \\
\text { Public external debt service 6/ } \\
\text { Debt service due on GRA credit 4/ }\end{array}$ & $\begin{array}{r}80 \\
13.8 \\
0.0\end{array}$ & $\begin{array}{r}75 \\
19.5 \\
0.2\end{array}$ & $\begin{array}{r}67 \\
17.7 \\
0.3\end{array}$ & $\begin{array}{r}59 \\
16.5 \\
0.4\end{array}$ & $\begin{array}{r}54 \\
14.1 \\
0.5\end{array}$ & $\begin{array}{r}41 \\
8.5 \\
1.1\end{array}$ & $\begin{array}{r}37 \\
10.8 \\
1.6\end{array}$ & $\begin{array}{r}36 \\
11.5 \\
1.9\end{array}$ & $\begin{array}{r}33 \\
10.4 \\
1.8\end{array}$ & $\begin{array}{r}31 \\
9.8 \\
1.6\end{array}$ & $\begin{array}{l}29 \\
8.8 \\
1.5\end{array}$ & $\begin{array}{l}25 \\
6.8 \\
0.9\end{array}$ & $\begin{array}{l}22 \\
4.7 \\
0.4\end{array}$ \\
\hline $\begin{array}{l}\text { In percent of Total External Debt } \\
\text { GRA credit to Ireland }\end{array}$ & 0.3 & 0.8 & 1.2 & 1.3 & 1.2 & 1.2 & 1.0 & 0.8 & 0.6 & 0.4 & 0.2 & 0.1 & 0.0 \\
\hline $\begin{array}{l}\text { In percent of Total External Debt Servi } \\
\text { Debt service due on GRA credit 4/ }\end{array}$ & 0.0 & 0.2 & 0.4 & 0.6 & 0.8 & 2.6 & 4.3 & 5.1 & 5.4 & 5.2 & 5.1 & 3.6 & 1.7 \\
\hline $\begin{array}{l}\text { In percent of Total Public External Deb } \\
\text { GRA credit to Ireland }\end{array}$ & 2.9 & 6.5 & 8.6 & 8.6 & 8.3 & 7.5 & 6.7 & 5.6 & 4.3 & 3.0 & 1.6 & 0.6 & 0.1 \\
\hline $\begin{array}{l}\text { In percent of Total Public External Deb } \\
\text { Debt service due on GRA credit 4/ }\end{array}$ & 0.1 & 0.8 & 1.7 & 2.2 & 3.2 & 12.6 & 14.8 & 16.1 & 17.1 & 16.6 & 16.9 & 13.1 & 8.0 \\
\hline
\end{tabular}

Sources: Irish Authorities, Finance Department, and IMF staff estimates.

$1 /$ Assumes full drawings.

/ Repurchases are assumed to be made as scheduled.

3/ Includes GRA basic rate of charge, surcharges and service fees.

$4 /$ Includes charges due on GRA credit and payments on principal.

5/ Staff projections for external debt, GDP, gross international reserves, debt servicing, and exports of goods and services, as used in the staff report that requests the proposed EFF.

$6 /$ Amortization of medium and long-term external debt and total interest payments. 


\section{IMPACT ON THE FUND’s LIQUIDITY POSITION AND Risk EXPOSURE}

7. The impact of the proposed extended arrangement on the Fund's liquidity and credit risk exposure is very substantial:

- $\quad$ The proposed arrangement would reduce Fund liquidity significantly (Table 4). Commitments under the proposed arrangement would reduce the one-year forward commitment capacity (FCC), which currently stands at about SDR 151 billion, by over 13 percent. ${ }^{11}$ This level of liquidity remains comfortable by historical standards. However, the liquidity position could change quickly, particularly given the current potential for other large requests for Fund support owing to stresses in some sovereign debt markets and the potential for spillovers, underscoring the need for the continued close monitoring of the Fund's liquidity position.

- If the first purchase is made, Fund credit to Ireland would represent almost 9 percent of total GRA Fund credit (Figure 4, Panel B), making Ireland one of the larger users of Fund resources. The share of the top five users of Fund resources of total outstanding credit would decrease by several percentage points to about 65 percent (Table 4 ).

- $\quad$ Potential total GRA exposure to Ireland would be a multiple of the current level of the Fund's precautionary balances. After the first purchase, Fund credit to Ireland would be over 68 percent of the Fund's current precautionary balances (Table 4), and the total access would be over $2 \frac{1}{2}$ times the current level of precautionary balances. Credit outstanding to Ireland will exceed the current level of precautionary balances through 2018, and average at over twice their level.

- In the event Ireland were to fully draw on resources available under the proposed arrangement, the charges accruing to Ireland's GRA obligations would far exceed the Fund's burden sharing capacity were they to fall into arrears. ${ }^{12}$ Charges on GRA obligations would equal about SDR 128 million in 2011, over $3 \frac{1}{2}$ times the current estimated residual burden-sharing capacity (Table 4).

\footnotetext{
${ }^{11}$ The FCC is the principal measure of Fund liquidity. The (one-year) FCC indicates the amount of GRA resources available for new financing over the next 12 months, and is calculated taking into account supplementary resources made available under borrowing arrangements including note purchase agreements. See Borrowing by the Fund-Operational Issues. In this connection, the Fund has received confirmation from most existing bilateral creditors of their intention to maintain their bilateral agreements in place under adequate safeguards after the amended NAB becomes effective.

${ }^{12}$ Under the burden-sharing mechanism, the financial consequences for the Fund that stem from the existence of overdue financial obligations are shared between creditors and debtors through a decrease in the rate of remuneration and an increase in the rate of charge, respectively. The mechanism is used to compensate the Fund for a loss in income when debtors do not pay charges. Under current Board decisions, no burden sharing
}

(continued) 
Table 4. Ireland-Impact on GRA Finances

(millions of SDR unless otherwise noted)

\begin{tabular}{|c|c|}
\hline & as of $12 / 3 / 2010$ \\
\hline \multicolumn{2}{|l|}{ Liquidity measures } \\
\hline $\begin{array}{l}\text { One-year Forward Commitment Capacity (FCC) } 1 / \\
\text { Impact on FCC on approval 2/ }\end{array}$ & $\begin{array}{r}151,334 \\
19,983\end{array}$ \\
\hline \multicolumn{2}{|l|}{ Prudential measures } \\
\hline $\begin{array}{l}\text { Fund GRA commitment to Ireland } \\
\text { in percent of current precautionary balances } \\
\text { in percent of total GRA credit outstanding } 3 /\end{array}$ & $\begin{array}{r}266 \\
37\end{array}$ \\
\hline $\begin{array}{l}\text { Fund GRA credit outstanding to top five borrowers } \\
\text { in percent of total GRA credit outstanding 3/ } \\
\text { in percent of total GRA credit outstanding including first Irish purchase }\end{array}$ & $\begin{array}{l}72 \\
65\end{array}$ \\
\hline Ireland annual GRA charges in percent of the Fund's residual burden sharing capacity for 2011 & 367.8 \\
\hline \multicolumn{2}{|l|}{ Memorandum items } \\
\hline Fund's precautionary balances (FY 2010) 4/ & 7,320 \\
\hline Fund's Residual Burden Sharing Capacity 5/ & 34.7 \\
\hline \multicolumn{2}{|l|}{ Sources: Irish authorities, Finance Department, World Economic Outlook, and IMF staff estimates. } \\
\hline \multicolumn{2}{|c|}{$\begin{array}{l}\text { 1/ The FCC is defined as the Fund's stock of usable resources less undrawn balances under existing } \\
\text { arragements, plus projected repurchases during the coming } 12 \text { months, less repayments of borrowing due one year forward, } \\
\text { less a prudential balance. } \\
\text { 2/ A single country's negative impact on the FCC is defined as the country's sum of Fund credit and undrawn commitments } \\
\text { minus repurchases one-year forward. Furthermore, Ireland would likely cease participating in the FTP, resulting in a parallel } \\
\text { reduction of prudential balances. } \\
\text { 3/ As of November } 12,2010 \text {. } \\
\text { 4/ Precautionary balances exclude amounts in Special Reserves attributable to pofits on gold sales in FY2010. } \\
5 / \text { Burden-sharing capacity is calculated based on the floor for remuneration at } 85 \text { percent of the SDR interest rate. Residual } \\
\text { burden-sharing capacity is equal to the total burden-sharing capacity minus the portion being utilized to offset deferred charges } \\
\text { and takes into account the loss in capacity due to nonpayment of burden sharing adjustments by members in arrears. }\end{array}$} \\
\hline
\end{tabular}

\section{ASSESSMENT}

\section{The proposed extended arrangement for Ireland intends to support the} authorities' economic program during a period of substantial adjustment and reduce the risk of international systemic spillovers. It seeks to address deep-rooted structural problems with a view to restoring confidence in the Irish economy's future. Specifically, it pursues a fundamental restructuring of the banking sector, while preserving the fiscal consolidation objective to lower the deficit and debt over the medium term. This, in turn, is expected to restore market confidence and stem potentially pernicious systemic spillovers.

\section{There are significant risks to the program that could affect Ireland's capacity to} repay the Fund. Achieving a gradual recovery of the economy is key. Given the high level of external debt, negative shocks to households' and businesses' repayment capacity, as a result, for instance, of lower-than-expected growth, would have the potential to lead to a

adjustments can be made that would result in a rate of remuneration below 85 percent of the SDR interest rate. While this limit could be changed, under the Articles the rate of remuneration cannot be below 80 percent of the SDR interest rate (Article V, Section 9(a)). No corresponding ceiling applies to the rate of charge. 
further deterioration in banks' balance sheets despite the comprehensive restructuring efforts, and put additional pressure on public sector debt. These, in turn, would add fiscal costs at a time when tax revenue performance would also be negatively impacted. Adhering to the fiscal targets and restructuring the financial sector would also require strong and continued political commitment and public support. Furthermore and notwithstanding a substantial recapitalization reserve, the ultimate need for bank recapitalization will not be known until early next year. Finally, market confidence may return more gradually than envisaged under the program if concerns about debt dynamics in Ireland and other members of the Eurozone intensify.

10. Overall, the proposed access would entail substantial risks to the Fund. The Fund would be highly exposed to Ireland in terms of both the stock of outstanding credit and the projected debt service, for an extended period and in a context of high overall debt and debt service burdens. The associated risks would be still larger should any of the risks to the outlook discussed above materialize. However, current circumstances are highly exceptional, requiring a strong sign of support from the international community in light of the high risk of international systemic spillovers. While Ireland's capacity to repay its obligations to the Fund, and other creditors, rests crucially on its ability to mobilize sizeable resources from the private sector in the medium term, the financial terms of Fund assistance, the authorities' commitment to their comprehensive adjustment program, the strong support of their European partners, and the Fund's preferred creditor status all serve to mitigate the financial risks to the Fund. 


\section{Ireland-Statement by the Staff Representative \\ Executive Board Meeting \\ December 10, 2010}

1. This statement provides information that has become available since the Staff Report was circulated to the Executive Board on December 4, 2010. The information does not alter the thrust of the staff appraisal.

2. The 2011 Budget was presented to the Parliament on December 7 and the budgetrelated financial resolutions were passed the same day with a comfortable majority, thus meeting the prior action. The 2011 Budget is broadly in line with the authorities' four-year National Recovery Plan (NRP) and the proposed measures are consistent with the policies agreed under the Fund-supported program.

- $\quad$ The expenditure package specifies the welfare cuts underpinning the $€ 0.9$ billion savings for 2011 indicated in the NRP. The reductions principally apply to universal and hence non-progressive benefit schemes, and benefits to working-age individuals and families.

- $\quad$ On the revenue side, Budget 2011 implements the major reforms identified in the $\mathrm{NRP}$, but provides greater specificity on income tax policy changes. A 10 percent reduction in personal income tax bands and credits will be supplemented by the abolition of the income ceiling up to which the Pay Related Social Insurance (PRSI) is payable, an increase in the PRSI contribution rate for the self-employed, and a merger of the income and health levies into a graduated universal social charge.

- $\quad$ The package also includes a sharp reduction in the stamp duty rate to 1 percent, while removing various exemptions, with a view to resuscitating the property market. 
December 16, 2010

\section{IMF Executive Board Approves €22.5 Billion Extended Arrangement for Ireland}

The Executive Board of the International Monetary Fund (IMF) today approved a three-year Extended Fund Facility (EFF) arrangement for Ireland to support the authorities' economic adjustment and financial stabilization program. The Fund arrangement amounts to SDR 19.5 billion (about $€ 22.5$ billion; or US $\$ 30.1$ billion), or the equivalent of about 2,322 percent of Ireland's IMF quota. The arrangement forms a critical part of a substantial financing package amounting to $€ 85$ billion (about US\$113 billion) from Ireland's European partners through the European Financial Stabilization Mechanism (EFSM) and European Financial Stability Facility (EFSF), and bilateral loans from the UK, Sweden and Denmark, and Ireland's own contributions.

The EFSM, EFSF and bilateral European lenders will provide $€ 45$ billion on similar maturities as the IMF's EFF. The Irish authorities will round out the total financing package through a contribution amounting to $€ 17.5$ billion from the nation's cash reserves and liquid assets. European Central Bank liquidity support is also an essential component of the overall economic and financial program.

"The Irish authorities have designed an ambitious policy package to address the economic crisis facing the nation," IMF Managing Director Dominique Strauss-Kahn stated. "It is a multi-year program targeting vulnerabilities in the banking system and aiming to restore prospects for growth - without which there can be no enduring solution to the crisis. The authorities designed a program with fairness in mind so that the burden of economic and financial adjustment is shared across all levels of society, with the most vulnerable groups the most protected."

Exceptional financial assistance from the IMF and Europe will support the authorities' efforts by providing sufficient financial resources to allow time for Ireland to restore market confidence and foster renewed growth and job creation, Mr. Strauss-Kahn noted.

The extended arrangement under the EFF for Ireland was approved under the Fund's exceptional access policy and fast-track Emergency Financing Mechanism procedures. As a 
result of the IMF Executive Board action, SDR 5 billion (about $€ 5.8$ billion) is immediately available to Ireland from the IMF.

Following the Executive Board's action on Ireland, Mr. Strauss-Kahn, who also serves as Chairman of the Board, stated:

"The Irish economy faces a crisis without parallel in its recent history. The new program, building on the authorities' recent efforts, steps up the pace and range of measures to address financial and fiscal stability concerns. A clear and realistic package of policies is set in a multi-year policy framework to restore Ireland's banking system to health, place its public finances on a sound footing, and reclaim growth.

"The strategy for the financial system rests on twin pillars: deleveraging and reorganization; and ample capitalization. In addition, structural measures - a special resolution scheme for deposit-taking institutions and a further strengthening of the supervisory system-will enhance stability.

"The National Recovery Plan forms the basis for the 2011 budget and also details fiscal consolidation measures through 2014. The fiscal plan makes pragmatic choices, and maintains Ireland's due regard to a social safety net. The process of budget formation will be reformed to safeguard these gains.

"To restore strong, sustainable growth the program includes a strategy to remove potential structural impediments to enhancing competitiveness and creating new employment opportunities.

"A financing package of $€ 85$ billion (about US\$113 billion) will support the comprehensive set of policies. Of this, the European Union and bilateral European lenders have pledged a total of $€ 45$ billion (about US $\$ 60$ billion). The Irish authorities are to contribute $€ 17.5$ billion from the nation's cash reserves and other liquid assets. The IMF contribution would be through a three-year SDR 19.5 billion (about $€ 22.5$ billion; or US $\$ 30.1$ billion) loan, representing about 2,322 percent of quota, under the Extended Fund Facility (EFF). The EFF ensures a realistic repayment schedule, given the time needed to complete an orderly overhaul of the banking system and broader structural reforms".

\section{ANNEX}

\section{Recent Economic Developments}

Despite the authorities' efforts to implement bold economic policies in a difficult environment, Ireland has faced intense economic and financial pressures in recent months. At the root of its problems is a critically-weakened banking sector that has yet to be restored to 
health and stands at the center of a negative dynamic that dampens economic recovery while creating further significant fiscal challenges.

The authorities have taken major measures to strengthen the banking sector but vulnerabilities remain acute. The National Asset Management Agency is taking over banks' land and property development assets; substantial capital has been injected, and sovereign guarantees have sought to reassure banks' creditors. However, market pressures continue to pose challenges to large rollover needs, threatening banking system solvency and placing a severe burden on the sovereign's finances. Layered on these real difficulties is the fall in domestic consumer and international investor confidence, with implications for growth and the cost of funding.

Moving early, the Irish authorities implemented sizeable fiscal consolidation over 2009-10. However, public finances were weighed down by a deep structural deficit, commitments to bank support, and weak growth. Public debt is, as a result, projected to end up close to 100 percent of GDP by end-2010. To help stabilize public debt, the authorities' fiscal consolidation plan includes another $€ 15$ billion in consolidation measures over 2011-14, equivalent to 9 percent of GDP.

The authorities' program aims to restore Ireland's banking system to health and put the nation's public finances on a sound footing, thus stimulating renewed confidence and a return to strong, sustained growth.

\section{Program Summary}

The authorities' program focuses on the following priority areas:

- Fundamental restructuring of the banking sector will entail extensive deleveraging and reorganization. While this process will take time, it will start immediately and will move with deliberate speed. A smaller, more robust, and better-capitalized banking system will emerge to serve the needs of the Irish economy. To support the banking sector's transition, banks will maintain higher capital adequacy standards to minimize market perceptions of weakness, and thereby achieve improved access to funding.

- The National Recovery Plan will form the basis of 2011 and subsequent budgets. The Plan strikes an appropriate balance between consolidation to achieve fiscal sustainability while mitigating adverse effects on growth and protecting the most vulnerable.

- Structural impediments to business environment that might underpin competitiveness in the years ahead, supporting growth, will be addressed under the program.

To achieve the program objective a multifaceted approach will be undertaken: 
- $\quad$ A fundamentally restructured banking system that downsizes the banking sector (while addressing market perceptions of weak bank capital positions).

- Safeguarding the fiscal consolidation plan to lower the deficit and debt over the medium term.

- Institutional reform to improve the shock-absorbing capacity of the economy: a special resolution regime for banks, stronger supervision, and greater budgetary oversight.

- $\quad$ Further reforms to improve the economy's efficiency to enhance growth potential.

- Large external financial assistance to manage the transition and reestablish muchneeded policy credibility.

The stability thus generated - along with improved competitiveness and increased credit flows - would underpin a return of confidence, and, hence, brighter employment and growth prospects.

\section{Background}

Ireland, which became of member of the IMF on August 8, 1957, has an IMF quota of SDR 838.40 million.

For additional information on the IMF and Ireland, see: http://www.imf.org/external/country/IRL/index.htm 